UNIVERSIDADE DE SÃO PAULO

ESCOLA DE ENFERMAGEM

\author{
DEISI CRISTINE FORLIN
}

\title{
A VISITA DOMICILIAR DO ENFERMEIRO NA ATENÇÃO BÁSICA: \\ UMA PROPOSTA DE PRÁTICA EMANCIPATÓRIA
}

São Paulo

2014 


\section{DEISI CRISTINE FORLIN}

\section{A VISITA DOMICILIAR DO ENFERMEIRO NA ATENÇÃO BÁSICA: UMA PROPOSTA DE PRÁTICA EMANCIPATÓRIA}

Dissertação de Mestrado apresentada ao Programa de Pós-Graduação em Enfermagem da Escola de Enfermagem da Universidade de São Paulo para obtenção do título de Mestre em Ciências

Área de concentração: Cuidado em Saúde

Orientador: Prof. ${ }^{a}$ Dr. ${ }^{a}$ Celia Maria Sivalli Campos

\section{São Paulo}


AUTORIZO A REPRODUÇÃO E DIVULGAÇÃO TOTAL OU PARCIAL DESTE TRABALHO, POR QUALQUER MEIO CONVENCIONAL OU ELETRÔNICO, PARA FINS DE ESTUDO E PESQUISA, DESDE QUE CITADA A FONTE.

Assinatura:

Data:

Catalogação na Publicação (CIP)

Biblioteca "Wanda de Aguiar Horta"

Escola de Enfermagem da Universidade de São Paulo

Forlin, Deisi Cristine

A visita domiciliar do enfermeiro na atenção básica: uma proposta de prática emancipatória / Deisi Cristine Forlin. São Paulo, 2014.

$138 \mathrm{p}$.

Dissertação (Mestrado) - Escola de Enfermagem da Universidade de São Paulo.

Orientadora: Prof. ${ }^{a}$ Dr. ${ }^{\text {a }}$ Celia Maria Sivalli Campos

Área de concentração: Cuidado em Saúde

1. Enfermagem da família. 2. Visita domiciliar. 3. Necessidades e demanda de serviços de saúde. 4. Saúde da família. I. Título. 
Nome: Deisi Cristine Forlin

Título: A visita domiciliar do enfermeiro na atenção básica: uma proposta de prática emancipatória.

Dissertação apresentada ao Programa de Pós-Graduação em Enfermagem da Escola de Enfermagem da Universidade de São Paulo para obtenção do título de Mestre em Ciências

Aprovado em:

\section{BANCA EXAMINADORA}

Prof. Dr: Instituição:

Julgamento:

Assinatura:

Prof. Dr: Instituição:

Julgamento: Assinatura:

Prof. Dr: Instituição:

Julgamento: Assinatura: 
Dedico este trabalho aos meus amados pais Nelci e Ivori; Meu querido esposo e companheiro Saulo; Às enfermeiras que participaram deste processo; e especialmente à minha orientadora, professora Celia. 


\section{AGRADECIMENTOS}

Aos meus pais, pilares da minha existência, pelo apoio e presença constante em minha vida.

Ao meu esposo, amigo, companheiro e porto seguro, Saulo.

À minha orientadora, professora Celia, por ter me acolhido nesse processo, pela primorosa orientação e pelo carinho com o qual me conduziu durante o processo de aprendizado e formação crítica. Às enfermeiras que brilhantemente participaram deste estudo. À professora Cassia Baldini Soares, pela valiosa colaboração na construção deste estudo.

À Rafaela, amiga de todos os momentos.

À professora Marilene Loewen Wall, que me iniciou nos caminhos da pesquisa e incentivou-me a ampliar meus horizontes.

A todos os integrantes do grupo de pesquisa "Fortalecimento e Desgaste no trabalho e na vida" pela colaboração para o enriquecimento deste estudo.

Ao CNPq pela bolsa que me permitiu dedicação exclusiva ao mestrado. 
"Fazer trabalhar o cérebro é muito mais difícil e muito mais fatigante que fazer trabalhar os seus músculos. Mas é preciso faze-lo, porque é o cérebro que comanda os músculos, e, se o não fizermos, serão outros cérebros que os comandarão".

Anton Pannekoek 
Forlin DC. A visita domiciliar do enfermeiro na atenção básica: uma proposta de prática emancipatória [dissertação]. São Paulo: Escola de Enfermagem, Universidade de São Paulo; 2014.

\section{RESUMO}

Introdução: $\mathrm{O}$ objeto desta pesquisa é a Visita Domiciliar (VD), um dos instrumentos da prática do enfermeiro na Atenção Básica (AB). Práticas em saúde foram compreendidas como trabalho, ou seja, uma atividade previamente intencionalizada para transformar as necessidades de saúde, com a finalidade de aprimorar respostas a elas. Necessidades de saúde foram compreendidas como necessidades de reprodução social dos grupos sociais que conformam a área de abrangência das Unidades de Saúde. A VD na $\mathrm{AB}$ é uma prática dirigida à população socialmente marginalizada, com vistas a fiscalizar e controlar comportamentos e hábitos considerados não saudáveis. Pressupõe-se que a VD pode constituir-se como prática emancipatória, ou seja, pode ser implementada a partir da reflexão sobre a origem das necessidades de saúde, para instrumentalizar os sujeitos para acessar seus direitos e lutar por eles, incentivar valores de solidariedade e resgatar a condição humana como condição social. Objetivo: Apresentar a VD, como prática emancipatória na AB. Método: Pesquisa-ação emancipatória, realizada com 12 enfermeiras da Coordenadoria de Saúde Centro Oeste, do município de São Paulo, que participaram de 12 oficinas para a elaboração de um roteiro de VD, que se constituirá em material pedagógico. O processo de elaboração conjunta do roteiro teve início com o aprimoramento conceitual e a reflexão sobre as práticas desenvolvidas pelo enfermeiro na $\mathrm{AB}$. O conteúdo das oficinas, gravado em áudio, foi transcrito e analisado à luz das categorias analíticas processo de trabalho em saúde e necessidades de saúde, propostas pelo campo da Saúde Coletiva. Resultados: O processo de elaboração do roteiro de VD promoveu reflexão e análise crítica das práticas tradicionais da $A B$, que reduzem a complexidade das necessidades de saúde a problemas e agravos clínicos. Apreenderam as necessidades de saúde como objeto das práticas na $\mathrm{AB}$ e expressaram a possibilidade de ampliação dessas, mediante a incorporação dos determinantes sociais do processo saúde-doença ao objeto do trabalho. As participantes identificaram que na $\mathrm{AB}$ a finalidade das práticas tem respondido a interesses alheios às necessidades de saúde da população, privilegiando o cumprimento de metas e indicadores pré-estabelecidos por programas ministeriais. $\mathrm{O}$ processo foi concluído com a elaboração de um roteiro para VD, como prática emancipatória Conclusão: A pesquisa-ação emancipatória efetivou a elaboração do roteiro de VD emancipatória pelas enfermeiras, por meio da reflexão das práticas tradicionais hegemônicas na $\mathrm{AB}$ à luz de conceitos da Saúde Coletiva.

PALAVRAS-CHAVE: Visita Domiciliar. Necessidades e demandas de serviços de saúde. Enfermagem da família. Programa Saúde da Família. 
Forlin DC. The nurse's home visit in Primary Health Care: an emancipatory practice proposal [dissertation]. São Paulo: Escola de Enfermagem, Universidade de São Paulo; 2014.

\begin{abstract}
Introduction: The aim of this research is the Home Visit (HV), one of the instruments for nursing practice in Primary Health Care (PHC). Health practices were understood as work, meaning a previously intended activity to transform health needs, with the goal of improving the response to them. Health needs were understood as the social reproduction needs of the social groups which conform to the range of the Health Units. The HV in PHC is a practice directed to the socially marginalized population, aiming to monitor and control behaviors and habits considered unhealthy. It is assumed that $\mathrm{HV}$ can be an emancipatory practice, meaning that it can be implemented through the reflection on the origin of the health needs, to aid subjects in accessing their rights and fight for them, incentive the solidarity values and restore the human condition as a social condition. Aim: To present HV as an emancipatory PHC practice. Method: Emancipatory research-action done with 12 nurses from the West Central Health Coordination, in the city of São Paulo, who participated in 12 workshops to elaborate a HV script, which will constitute pedagogical material. The group elaboration process for the script began with the conceptual improvement and reflection on the practices developed by nurses in PHC. The content of the workshops, recorded in audio, was transcribed and analyzed in light of the analytical categories of the work process in health, and health needs, proposed by the Collective health field. Results: The process to elaborate the HV script promoted reflection and critical analysis of the traditional HV practices, which reduce the complexity of health needs to clinical problems and aggravations. The health needs were raised as an object of the HV practices and these expressed the possibility of expansion, with the incorporation of social determinants to the health-sickness process for the object of the work. The participants identified that in HV the aim of the practices has responded to interests foreign to the health needs of the population, privileging the fulfillment of goals and pre-established indicators from ministerial programs. The process was concluded with the elaboration of a HV script, as an emancipatory practice. Conclusion: The emancipatory research-action made possible the elaboration of the emancipatory HV script by the nurses, through reflection on the traditional hegemonic practices in PHC in light of Collective Health concepts.
\end{abstract}

KEYWORDS: Home visit. Health Services Needs and Demand. Family Nursing. Family Health Strategy. 
Forlin DC. La visita domiciliaria del enfermero en la atención primaria: una propuesta de práctica emancipadora [disertación]. São Paulo: Escola de Enfermagem, Universidade de São Paulo; 2014.

\section{RESUMEN}

Introducción: El objeto de esta investigación es la Visita Domiciliaria (VD), uno de los instrumentos de la práctica del enfermero en la Atención Primaria (AP). Se comprendieron las prácticas de salud como trabajo, es decir, una actividad previamente intencionalizada para transformar las necesidades de salud, con el fin de mejorar las respuestas a ellas. Las necesidades de salud se entendieron como necesidades de reproducción social de los grupos sociales que conforman el área cubierta por las Unidades de Salud. La VD en la AP es una práctica designada a la población socialmente marginada, con el fin de monitorear y controlar comportamientos y hábitos considerados insalubres. Se supone que la VD puede constituirse como una práctica emancipadora, es decir, puede ser realizadas a partir de la reflexión sobre el origen de las necesidades de salud, para instrumentar a los sujetos a acceder a sus derechos y luchar por ellos, estimular valores de solidaridad y rescatar la condición humana como una condición social. Objetivo: Presentar la VD como practica emancipadora en la AP. Método: Investigación-Acción emancipadora, realizado con 12 enfermeras de la Coordinadora de Salud del Medio Oeste, en São Paulo, cuales participaron de 12 talleres para elaboración de un guión de $\mathrm{VD}$, que se compondrá en el material pedagógico. El proceso de elaboración conjunta del guión empezó con el mejoramiento conceptual y la reflexión sobre las prácticas desarrolladas por enfermeros en la AP. El contenido de los talleres, grabadas en audio, fue transcrito y analizado por las categorías analíticas proceso de trabajo y necesidades de salud y de salud, propuestas por el campo de la Salud Colectiva. Resultados: El proceso de elaboración del guión de VD ocasiono la reflexión y el análisis crítico de las practicas tradicionales da la AP, que reducen la complejidad de las necesidades de salud a problemas clínicos. Aprehendieron las necesidades de salud como objeto das practicas en la AP y expresaron la posibilidad de su ampliación, mediante la incorporación de los determinantes sociales del proceso salud-enfermedad al objeto de trabajo. Las participantes identificaron que el fin de las practicas en la AP tiene respondido a otros intereses que las necesidades de salud de la población, privilegiando el cumplimiento de metas y indicadores preestablecidos por programas del Ministerio de la Salud. El proceso se concluyo con la elaboración de un guión para VD, como practica emancipadora. Conclusión: La investigación-acción emancipadora efectivo la elaboración del guión de VD emancipadora por las enfermeras, por medio de la reflexión de las practicas hegemónicas tradicionales en la AP a la luz de los conceptos de la Salud Colectiva.

PALABRAS-CLAVE: Visita Domiciliaria. Necesidades y demandas de servicios de salud. Enfermería de la familia. Estrategia de Salud Familiar. 


\title{
LISTA DE SIGLAS
}

\author{
AB Atenção Básica \\ ACS Agente Comunitário de Saúde \\ EEAN Escola de Enfermagem Anna Nery \\ ESF Estratégia Saúde da Família \\ DNSP Departamento Nacional de Saúde Pública \\ PACS Programa de Agentes Comunitários de Saúde \\ PIASS Programa de Interiorização das Ações de Saúde e Saneamento \\ PSF Programa Saúde da Família \\ SESP Serviço Especial de Saúde Pública \\ UBS Unidade Básica de Saúde \\ VD Visita Domiciliar \\ VNA Visiting Nurses Association
}




\section{SUMÁRIO}

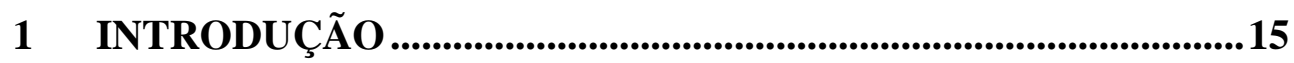

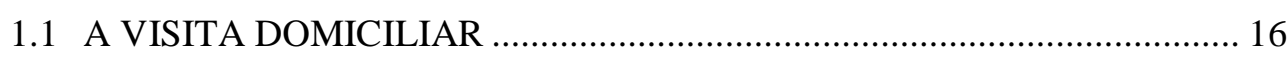

1.2 A VISITA DOMICILIAR NAS PRODUÇÕES CIENTÍFICAS .................. 27

2 CONSIDERAÇÕES TEÓRICAS ..................................................34

2.1 TRABALHO E PROCESSO DE TRABALHO ......................................... 35

2.2 PROCESSO DE TRABALHO EM SAÚDE E EM ENFERMAGEM ........... 37

2.3 NECESSIDADES DE SAÚDE E DETERMINAÇÃO SOCIAL DO PROCESSO SAÚDE-DOENÇA ............................................................... 40

3 FINALIDADE E OBJETIVOS ....................................................45

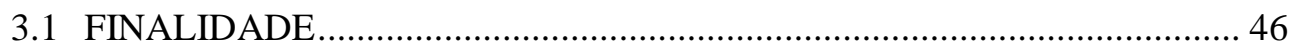

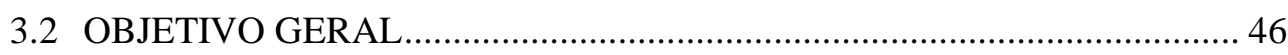

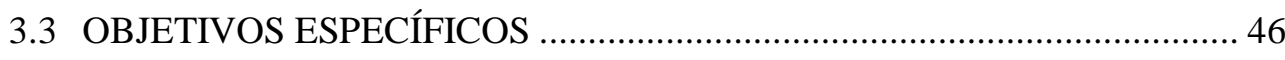

4 PROCEDIMENTOS METODOLÓGICOS .....................................47

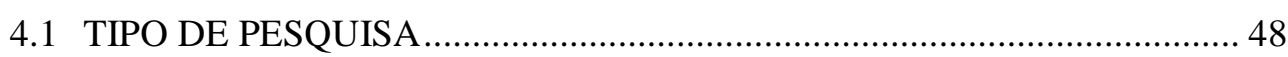

4.1.1 Da Pesquisa-Ação e Pesquisa-Ação Emancipatória ..................................... 49

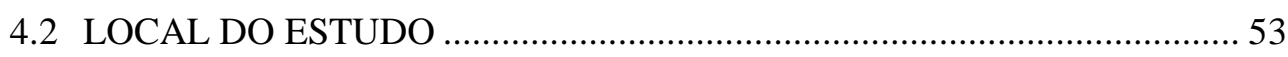

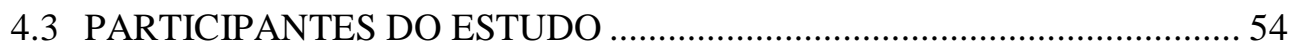

4.4 CAPTAÇÃO DE MATERIAL INFORMATIVO .......................................... 55

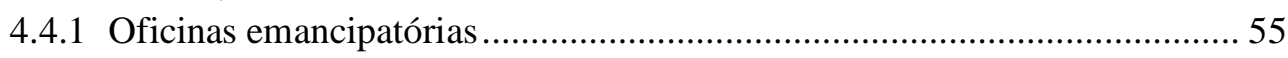

4.4.2 Descrição das oficinas emancipatórias ........................................................ 57

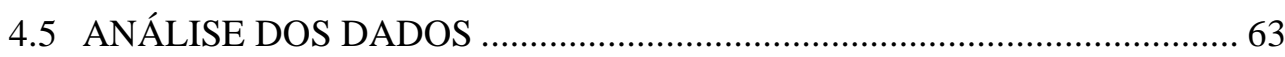

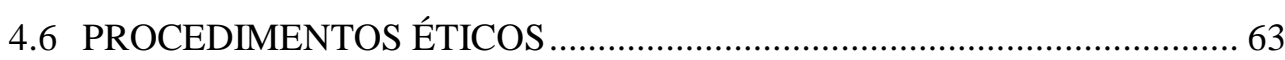

5 RESULTADOS E ANÁLISE ...................................................64

5.1 DA CRÍTICA SOBRE A FALTA DE DOMÍNIO À APREENSÃO DA FINALIDADE COMO CONDUTORA DO PROCESSO DE TRABALHO EM SAÚDE.

5.2 DA CRÍTICA AO OBJETO HEGEMÔNICO DA CLÍNICA À APREENSÃO DE NECESSIDADES DE SAÚDE COMO OBJETO DO PROCESSO DE TRABALHO EM SAÚDE

6 DISCUSSÃO

7 CONSIDERAÇÕES FINAIS .................................................102 


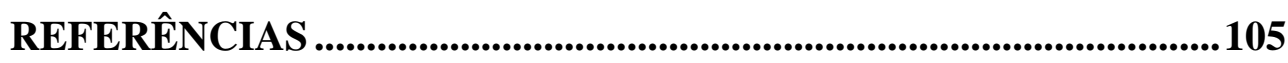

APÊNDICES...........................................................................117 APÊNDICE I - ROTEIRO PARA MATERIAL AUDIOVISUAL DE VISITA

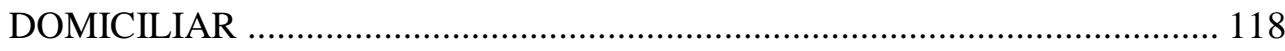

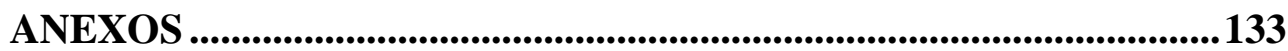

ANEXO I - TERMO DE CONSCENTIMENTO LIVRE E ESCLARECIDO ... 134 ANEXO II - APROVAÇ̃̃O COMITÊ DE ÉTICA EM PESQUISA DA ESCOLA DE ENFERMAGEM DA UNIVERSIDADE DE SÃO PAULO ……...136 ANEXO III - APROVAÇÃO COMITÊ DE ÉTICA EM PESQUISA DA SECRETARIA MUNICIPAL DE SAÚDE DE SÃO PAULO 


\section{APRESENTAÇÃO}

Minha aproximação com a pesquisa teve início ainda na graduação em enfermagem na Universidade Federal do Paraná, com a inserção em Grupo de Pesquisa e o desenvolvimento de projetos de Iniciação Científica. Os estudos seguiam a temática do câncer de mama em mulheres, na área de Saúde da Mulher.

As pesquisas realizadas durante a graduação resultaram nos artigos: "Government programs about breast cancer control in women: update" e "Cuidado de enfermagem para o câncer de mama na atenção básica: o olhar das usuárias" (em avaliação). No levantamento de materiais para as pesquisas, conheci uma organização não-governamental que desenvolvia ações sobre o câncer de mama, na qual participei por um período como voluntária, desenvolvendo educação em saúde à mulheres.

Essa experiência de desenvolver ações educativas, associada às atividades da licenciatura, possibilitaram que eu identificasse minha afinidade pela área acadêmica, o que motivou meu ingresso no mestrado.

No mestrado, tive a feliz oportunidade de me aproximar dos conceitos da Saúde Coletiva, que promoveu não apenas a ampliação da temática de estudo, mas principalmente, meu modo de olhar a realidade. Pude compreender a relação histórico-dialética que envolve os processos sociais, como os modos de trabalhar e viver dos distintos grupos sociais determina o adoecimento, e como as práticas de saúde articulam-se para atender as necessidades de saúde da população.

Ao iniciar o processo não imaginava identificar-me de tal forma com os conceitos do referencial teórico da Saúde Coletiva. Atribuo a responsabilidade dessa afinidade à minha orientadora, exemplo de profissional e pessoa, professora que transmite seus conhecimentos com tal zelo e dedicação, como outra ainda não conhecera.

Encontrei no arcabouço da Saúde Coletiva o aconchego e fortalecimento para as inquietações sociais que me afligem; primeiro, por 
conseguir explicá-las, e segundo, por mostrar que há possibilidade de intervir sobre elas. 
1 Intraduçãa 


\section{INTRODUÇÃO}

Esta pesquisa tomou como objeto de estudo a Visita Domiciliar* (VD), um dos instrumentos da prática do enfermeiro na Atenção Básica $(\mathrm{AB})$.

A VD, que passou por um período de declínio na $\mathrm{AB}$ com o domínio do modelo médico-privatista, adotado a partir dos anos 70, voltou a ser uma prática de destaque com a Estratégia de Saúde da Família (ESF), realizada majoritariamente pela equipe de enfermagem ou por trabalhadores supervisionados pelo enfermeiro (Escorel et al., 2007; Fertonani, Pires, 2010).

Com a proposta de novas bases e diretrizes assistenciais, centradas na família em seu contexto físico e social, os documentos do Ministério da Saúde abordam a VD como instrumento para conhecer o cenário da realidade familiar e monitorar a situação de saúde das famílias, mediante visitas programadas ou de acordo com a demanda espontânea, por meio dos profissionais das equipes de Saúde da Família (Brasil, 1997; 2007; 2012).

\subsection{A VISITA DOMICILIAR}

As práticas em saúde são compreendidas como processos sociais, vinculados a um conjunto de conhecimentos que não são neutros, pois sofrem influências políticas econômicas e sociais dos diversos contextos históricos (Almeida, Rocha, 1989).

\footnotetext{
* Há autores que utilizam a terminologia visita domiciliária (Cruz, Bourget, 2010; Egry, Fonseca, 2000; Gaíva, Siqueira, 2011; Lima, Silva, Bousso, 2010; Mandú et al., 2008; Mazza, 1994; Sossai, Pinto, 2010; Takahashi, Oliveira, 2001). No entanto, os que apresentam uma definição entre as diferenças de terminologia (Egry, Fonseca, 2000; Mandú et al., 2008; Sossai, Pinto, 2010), reafirmam a definição de Egry e Fonseca (2000). Estas autoras trazem que o termo correto é domiciliária, justificam apresentando que a nomenclatura domiciliar corresponde a um verbo transitivo direto, que significa: "dar domicílio a; recolher em domicílio; fixar residência ou fixar domicílio", enquanto que domiciliário faz referência a um "adjetivo relativo a domicílio, feito no domicílio e cujo feminino é domiciliária” (Egry, Fonseca, 2000, p. 236).

Neste estudo optou-se pelo termo Visita Domiciliar, conforme utilizado nos documentos do Ministério da Saúde e no descritor de Ciências da Saúde da Biblioteca Virtual em Saúde.
} 
Dessa forma, faz-se necessário contextualizar a VD de acordo com as características sócio-históricas predominantes em cada período, uma vez que as ações de saúde são concernentes com cada contexto políticoeconômico.

No final da Idade Média práticas de VD já eram realizadas para o cuidado de pessoas doentes. Esse período marcou a transição do modo de produção feudal para o pré-capitalismo (Almeida, Rocha, 1989), e a Igreja Católica ainda regulava as relações sociais, exercendo massiva influencia moral, intelectual e econômica. As grandes epidemias que dizimavam milhares de pessoas, em associação com desastres naturais, dificultavam o desenvolvimento sociopolítico e reforçavam as crenças supersticiosas (Espirito Santo, 2007).

Nesse contexto, o cuidado de saúde visava o conforto da alma do doente e também servia como uma forma de expiação dos pecados, tanto para o doente como para o cuidador, pois a doença era interpretada como um castigo de Deus (Almeida, Rocha, 1989; Espirito Santo, 2007; Geovanini et al., 2010; Mazza, 1994; Molina, 1973; Paixão, 1979; Silva, 1989).

Marco desse período foi a Confraria da Caridade, organizada na Itália por São Vicente de Paula, consistiu em uma associação de damas da caridade que realizavam visitas nos domicílios e ações voltadas à alimentação e higiene pessoal de doentes (Espírito Santo, 2007). Quando as VD passaram a ser realizadas para a execução de procedimentos orientados por médicos, as mulheres que integravam a Confraria passaram a ser selecionadas segundo critérios não mais associados à origem social da mulher, mas sim por saberem ler e escrever para que recebessem orientações sobre normas de comportamento, noções de enfermagem e de cuidados prescritos por médicos (Molina, 1973; Paixão, 1979).

Essas mulheres constituíram o Instituto das Filhas de Caridade, ordem religiosa responsável pela formação para a VD e pelo manual para essa prática, o Manual das Filhas de Caridade (Mazza, 1994; Pereira, 2001), que continha dentre outras orientações, os itens abaixo descritos: 
1. [...] Nada equivale a uma Visita de Enfermagem Domiciliar, repetida todos os dias em horas diferentes.

2. Se por acaso, vos fecharem a porta, retirai-vos sem nada dizer.

3. Diante de uma companhia duvidosa (família desajustada, pessoa de outra religião) ir diretamente ao doente, cumprimentando-o simplesmente.

4. Ocupar-se exclusivamente do doente, agir como se estivesse sozinho, não escutar nada e nem olhar para nada.

5. Terminados os cuidados e as determinações feitas, sair rapidamente.

6. Desconfiar de um homem só, doente.

7. Conforme as doenças, elas darão os remédios, farão sangrias, lavagens e outros medicamentos.

8. Reclamar sempre a receita antes de começar a lê-la atentamente até o fim [...]

9. Em todos cuidados pedir a uma pessoa da família ou vizinha, sempre a mesma, para auxiliá-la, a fim de fazêlos melhor e mais depressa com menor sofrimento para o doente." (Augusto \& Franco, 1980 apud Pereira, 2001, p.47).

No Brasil colônia o cuidado aos doentes marginalizados de toda ordem - pobres, forasteiros, soldados, marinheiros e loucos - seguia principalmente o modelo religioso, assistencialista e caritativo (Mazza, 1994), praticado por escravos e por voluntários, religiosos e leigos, nas Santas Casas de Misericórdia (Geovanini et al., 2010; Mazza, 1994). Contava-se também com os saberes populares, que mesclavam conhecimentos de várias culturas, dentre elas a africana. Segundo Paixão (1979), quando se identificava escravos com habilidades para cuidados à saúde, esses eram alugados pelos senhores para servirem a "doentes" em seu domicílio.

Na Europa, com a consolidação do modo de produção capitalista, a religião passou a não mais ocupar um lugar central na sociedade (Valla, Stotz, Algebaile, 2005). “A preocupação com a salvação da alma é substituída pela preocupação com a saúde dos corpos, que adquirem importância como instrumentos produtores de mercadorias e fatores essenciais do processo de acumulação de capital" (Silva, 1989, p.59).

A exigência de mão de obra saudável para produção nas fábricas levou à marginalização do cuidado em saúde, que passou a ser desenvolvido por mulheres que não serviam para a indústria (Almeida, Rocha, 1989; 
Silva, 1989), eram despreparadas e mal remuneradas. Nesse período as ordens religiosas foram substituídas pelo Estado na direção dos hospitais (Molina, 1973; Nauderer, Lima, 2005; Paixão, 1979). O controle da assistência à saúde vinculou-se ao Estado, "como uma forma de garantir a reprodução do capital, reestabelecendo a capacidade de trabalho do operariado" (Geovanini et al., 2010, p.22). Interesses políticos e econômicos se sobrepunham para a manutenção da saúde, compreendida não como uma necessidade ou direito, mas como modo de manter a produtividade e o lucro (Calipo, Soares, 2013; Espirito Santo, 2007; Geovanini et al., 2010; Pereira, 2001).

A disponibilidade de mão de obra era viabilizada pela população que migrava para as cidades, expulsa do campo, pela incorporação nas fábricas do trabalho infantil e de mulheres, que trabalhavam em largas jornadas de trabalho, sob condições precárias de higiene, alimentação e moradia. A consequência foi o aumento da produção de mercadorias, mas também da desnutrição, de acidentes e intoxicações, bem como o aumento da mortalidade infantil e da disseminação de tuberculose (Geovanini et al., 2010, p.22).

Esse foi também o contexto em que a VD tornou-se instrumento do trabalho em saúde que, se por um lado foi incorporada de conhecimentos científicos da época, deixando de ser apenas instrumento para caridade, por outro continuou mantendo o objetivo de fiscalização e de controle, para convencimento de mudança de hábitos e de comportamento, especialmente os relacionados à higiene, para manter a ordem, a limpeza dos ambientes e o controle sanitário.

Com esse objetivo, na Inglaterra de 1862, uma organização de saúde pública passou a contratar mulheres para visitar domicílios e famílias (Cowley, 2007), para orientar sobre a limpeza das casas e o cuidado com as crianças (Mumford, 1968). Em vista dos resultados positivos, a Sociedade Epidemiológica de Londres passou a treinar mulheres, dando origem à função de visitadora sanitária, que passaram a ser remuneradas pelo Estado (Mazza, 1994; Mumford, 1968; Smith, 1995). 
Nos Estados Unidos essa função teve início em 1893, com a criação da "Visiting Nurses Association" - VNA, associação de caráter filantrópico, coordenada por mulheres da alta sociedade, que contratava enfermeiras treinadas para prestar assistência a pobres e doentes (Mazza, 1994).

A ampliação do número de VNAs foi determinada pela imigração para o nordeste do país, para atender o aumento de pessoas acometidas por doenças infecciosas, como a varíola e poliomielite. Havia a necessidade de manter as pessoas pobres fora dos hospitais, que naquele período eram ocupados por indivíduos das classes altas, quando esses apresentavam quadros mais graves que não poderiam ser tratados no domicílio pelo médico da família (Buhler-Wilkerson, 1985). A partir da iniciativa da VNA, no ano de 1902 foi criada a Escola de Enfermeiras Visitadoras, para desenvolver trabalhos na área materno-infantil e para indivíduos com tuberculose (Mazza, 1994; Pereira, 2001).

No Brasil, o processo de substituição do controle dos hospitais pelas religiosas para o controle do Estado, na figura dos médicos, ocorreu no final do século XIX, com a incorporação do modo de produção capitalista, o que determinou a necessidade de formação de profissionais de saúde (Espirito Santo, 2007; Geovanini et al., 2010; Mazza, 1994; Paixão, 1979).

Consequência da característica organização do trabalho no modo de produção capitalista, que tem como resultado a precarização das condições de vida do trabalhador, da mesma forma que na Inglaterra, as cidades brasileiras foram assoladas por epidemias e endemias (Geovanini et al., 2010; Rizzotto, 1999), tendo sido necessárias medidas para o controle dessa situação pelo governo. A epidemia de gripe espanhola foi relatada por Freire e Amorim (2008) como um grande marco para que medidas sanitárias fossem tomadas. A abrangência dessa gripe foi tal que atingiu o presidente eleito em 1918, Rodrigues Alves, que foi a óbito antes de assumir o mandato.

Assim, as epidemias passaram a ser consideradas nas ações adotadas pelos governantes, que além da intenção de reverter a imagem do país no exterior, amparado pelos princípios liberais que norteavam o governo 
republicano instaurado, "defendia a universalização de certos benefícios, como a saúde e a educação" (Rizzotto, 1999, p.16), em parte para aplacar as greves operárias que tiveram seu auge entre 1917 e 1920, mas primordialmente porque era necessário manter saudável a mão-de-obra para manutenção da economia agroexportadora.

As principais ações desenvolvidas no domicílio eram voltadas ao controle do ambiente, seguindo uma proposta "campanhista/policial", voltadas, sobretudo, ao combate do vetor e centradas nos efeitos do problema e não em sua origem. Tais ações estavam a cargo da Polícia Sanitária, das brigadas "mata-mosquitos" e das Delegacias Sanitárias, sob responsabilidade do serviço de Inspeção de Saúde Pública do Porto do Rio de Janeiro (Geovanini et al., 2010; Pereira, 2001; Rizzotto, 1999).

Como descreveu Pereira (2001, p.54), as ações tinham caráter controlador e fiscalizatório, exercidas de maneira coercitiva e autoritária, voltadas para o controle do ambiente, como o "controle de vetores nos domicílios, remoção de cadáveres, aplicação compulsória de vacinas nos indivíduos em suas residências".

Assim como na Europa no século XVIII, as medidas adotadas no Brasil tinham intuito de controlar doenças e moralizar a população urbana, diretamente associada ao modo de produção vigente (Geovanini et al., 2010; Mazza, 1994).

O controle de doenças estava atrelado também ao saneamento dos portos, para atender as demandas do mercado agroexportador (Calipo, Soares, 2013; Geovanini et al., 2010; Mazza, 1994; Paixão, 1979), embora “a precária situação da Saúde Pública, nas cidades portuárias, nunca representaram um real empecilho para as relações econômicas do Brasil com os outros países, já que a própria política de saneamento constituía oportunidade de investimentos para o capital estrangeiro (Rizzotto, 1999, p.4)

Desse modo, as ações de saúde pública podem ser referidas como promotoras das escolas de enfermagem no Brasil (Mazza, 1994), tendo como marco a publicação de um artigo que abordava a necessidade de 
enfermeiras visitadoras para educação sanitária (Mazza; 1994; Paixão, 1979; Santos, Kirschbaum, 2008). A necessidade de formar visitadoras sanitárias adveio da ineficácia dos serviços públicos e da indisposição dos médicos sanitaristas em desenvolver as visitas, vistas como algo inferior para seu status social e de pouca cientificidade (Santos, Kirschbaum, 2008). Portanto, é possível afirmar que no Brasil a prática da VD desde sua origem esteve associada a controle de hábitos e comportamentos da população pobre, com intuito de evitar a disseminação de doenças transmissíveis.

De acordo com Mazza (1994) as visitas realizadas no período inicial do século XX tinham caráter preventivo, sendo consideradas as precursoras para regulamentação da enfermagem como profissão.

Com a criação do Departamento Nacional de Saúde Pública (DNSP) teve início o serviço de visitadoras no setor de Profilaxia da Tuberculose. Pensando em estender essa assistência às demais doenças transmissíveis, Carlos Chagas, com incentivo internacional da Fundação Rockfeller, traz para o Brasil, no ano de 1921, enfermeiras americanas para capacitar as enfermeiras brasileiras para as visitas. No ano seguinte o DNSP, com auxilio das enfermeiras norte-americanas, sob a liderança da enfermeira Parsons, deu início ao curso emergencial de Visitadoras de Higiene, com duração de seis meses (Freire, Amorim, 2008). Essas profissionais realizavam orientações às famílias quanto a aspectos de higiene, com vistas a eliminação das grandes epidemias e doenças infecciosas da época, principalmente a tuberculose; bem como abordavam questões de saúde infantil (Mazza, 1994; Paixão, 1979; Pereira, 2001; Santos, Kirschbaum, 2008).

O desenvolvimento da VD no Brasil acompanhou o mesmo processo que na Inglaterra da Revolução Industrial, uma prática de saúde utilizada para controlar doenças transmissíveis e para monitorar de alguma forma a saúde de crianças de uma dada classe social, a classe pobre, potencial força de trabalho. Já o destaque para o controle de doenças transmissíveis, uma das características do processo de urbanização desordenada, além da necessidade de conter o avanço, especialmente da tuberculose, entre a população mais pobre, (Mazza, 1994; Rizzotto, 1999; Santos, Kirschbaum, 
2008; Porto, Amorim, 2010), estava associado também ao potencial de contágio da classe dominante.

Com a expansão dos cursos de visitadoras, fundou-se a Escola de Enfermeiras do DNSP, seguindo o modelo de nightingaleano (atual Escola de Enfermagem Anna Nery - EEAN), essa serviu como modelo padrão para as demais escolas de enfermagem no país até meados de 1930.

Com o propósito de preparar profissionais voltados à melhora das condições sanitárias da população, as primeiras alunas formadas pela Escola de Enfermeiras do DNSP foram contratadas pelo DNSP, para atuar no Serviço de Enfermeiras desse departamento (Freire, Amorim, 2008). Prosseguindo os trabalhos de educação sanitária para profilaxia da tuberculose e higiene infantil, expandindo-se, em 1926, para orientações quanto à higiene pré-natal (Paixão, 1979).

No período de 1921 a 1931, vigorou no DNSP o Serviço de Enfermeiras, com o objetivo de "criar um serviço de enfermeiras visitadoras sanitárias para trabalhar preventivamente nas campanhas governamentais" (Geovanini et al., 2010, p.355), e desenvolver ações fragmentadas e focalizadas para a população pobre. As características dessas ações, somadas às precárias condições de trabalho, contribuíram para o insucesso desse serviço (Rizzotto, 1994).

Pereira (2001) refere que na década de 30 já era possível observar a mudança nas práticas de saúde pública, com ações não mais de enfoque coletivo, mas voltadas à assistência médica individual, colaborando para a "reprodução e manutenção desta força de trabalho dentro dos padrões exigidos para aquele momento histórico" (Pereira, 2001, p. 66).

A necessidade de desenvolvimento de programas sanitários levou o Governo Federal a propor cursos, com o propósito de divulgar conhecimentos de higiene e de educação sanitária (Santos, Faria, 2010). Nas décadas de 30 e 40, o Departamento Nacional de Saúde Pública organizou cursos intensivos de preparação de sanitaristas para os serviços de visitação domiciliar e para atuar nos dispensários (tratamento de tuberculose e hanseníase) e centros de saúde (Pereira, 2001; Santos, Faria, 2010). 
Nos anos 40 permaneceu o escopo higienista, mas agora com enfoque "menos autoritário", ou, de alguma forma, menos evidenciado (Santos, Kirschbaum, 2008). Resultado de uma parceria entre os governos brasileiro e estadunidense, por ocasião da acentuada exploração da borracha na região amazônica, e consequente fluxo de imigrantes para essa região, foi criado em 1942, o fundação de Serviço Especial de Saúde Pública - SESP, para atender os diversos riscos e agravos que acometiam a população que ali passou a viver por consequência da extração da borracha (Mazza, 1994; Pereira, 2001). As ações voltavam-se para o combate da malária, de modo a garantir a extração da borracha para subsidio de guerra dos Estados Unidos (Silva, 1989).

Para atender os agravos que se interpusessem à extração da borracha, instituiu-se o curso de visitadora sanitária para atuar nos Postos de Higiene do SESP. Além da formação profissional, as alunas, que era selecionadas a partir da localidade onde residiam, aprendiam "noções de educação doméstica, atuando nas atividades de copa, cozinha, rouparia, arrumação e limpeza em geral da casa, mercado, quintal, horta, criação de aves e acompanhando o trabalho dos serviçais" (Santos, Kirschbaum, 2008, p. 224). A justificativa para tal aprendizado era intervir junto a famílias mais pobres, consideradas pelo Estado, como carentes de condições de higiene na habitação. Havia uma sistematização prévia à visitação, com elaboração de roteiro, estabelecimento de tempo para cada visita, prioridade na ordem dos domicílios de acordo com a doença do visitado para evitar infecções cruzadas (Santos, Kirschbaum, 2008).

Evidencia-se portanto, que as mudança ocorreram apenas no método da prática da VD, contudo, o seu intuito e a população a quem eram destinadas continuou a mesma, desde a sua origem na Inglaterra do século XIX, quando foi instituída como prática de saúde.

De acordo com Pereira (2001), as VD eram realizadas pelas visitadoras sanitárias, sob supervisão de enfermeiras, que realizavam ações para a higiene materna e infantil, como programas educativos para gestantes e mães, além da educação sanitária às crianças. 
A partir da a década de 1950, com a crescente industrialização e os avanços na medicina, houve um incremento na expectativa de vida e redução da mortalidade nos diferentes ciclos de vida. No entanto, em decorrência do desordenado crescimento populacional dos centros urbanos, aliados à condições de vida precárias, não tardou para que epidemias já controladas voltassem a assolar milhares de pessoas em situação de miséria, desempregados e aqueles "sem as mínimas condições de vida, alijados do acesso a saúde, educação, moradia, lazer, etc.” (Geovanini et al. 2010, p.222).

Embora fosse evidente a associação entre as condições de trabalho e vida e os agravos que acometiam especialmente a população trabalhadora pobre, as ações de saúde continuavam pautadas no fenômeno saúde-doença associado a condições ambientais, como se fossem fenômenos naturais, isolados das condições de reprodução social dos sujeitos.

Esse período marca uma dicotomia entre a saúde pública e o âmbito da clínica médica, com a predominância de práticas centradas na cura do indivíduo, com referencia ao profissional médico e relacionadas ao domínio hospitalar (Campos, Soares, 2013).

A crise instaurada em meados da década de 1970, que ocasionou a recessão na economia dos países latino-americanos, tendo como consequências o arroche salarial, o agravamento da inflação, a crescente da dívida externa, o aumento do desemprego e do déficit fiscal, salientou ainda mais as desigualdades sociais. Com isso, as ações centradas na doença mostraram-se insuficientes. Portanto, na Conferência de Alma-Ata, em 1978, estipulou-se a Atenção Primária à Saúde como, preferencialmente, o primeiro contato da população com os serviços de saúde e como estratégia para alcançar um maior nível de saúde para todos (Mendes, 2012).

Em nível nacional, no âmbito da Saúde Pública, as ações propostas tinham caráter simplificado e focalizadas à população pobre (Mendonça, 2008; Geovanini et al., 2010). Dentre essas ações, o Programa de Interiorização das Ações de Saúde e Saneamento - PIASS, visava, com a utilização de profissionais de nível elementar recrutados nas próprias 
comunidades, desenvolver atividades de prevenção e educação da população, inclusive por meio da VD (Tanaka et al., 1992).

Nesse contexto, em que as práticas da Saúde Pública eram coerentes com a finalidade de conter agravos à saúde com racionalização de custos para o Estado, a VD continuou sendo desenvolvida com enfoque na prevenção, por meio de controle de hábitos e comportamentos. Sendo também utilizada, com os agentes locais de saúde, como instrumento de assistência, novamente realizada por leigos, assim como antes de ser considerada uma prática de trabalho profissional e sistematizada.

Na década de 1990, o governo lançou o Programa Saúde da Família (PSF), posteriormente nominado de Estratégia Saúde da Família (ESF) como proposta de reorganização da AB. Nessa Estratégia destaca-se a figura dos Agentes Comunitários de Saúde (ACS), trabalhadores leigos oriundos da comunidade local (Brasil, 2001a), em moldes semelhantes aos agentes de saúde dos anos 1980, que realizavam práticas leigas a população de locais distantes do país, em que não chegavam práticas realizadas por profissionais da saúde.

Com a implementação da ESF a VD voltou a ser preconizada como uma prática privilegiada para atenção à saúde (Brasil, 2001b), destacada como um dos grandes diferenciais na $\mathrm{AB}$ e com o objetivo monitorar a situação de saúde das famílias do território.

Assim como nas ações da medicina comunitária, ainda na ESF a VD é realizada principalmente por trabalhadores advindos da própria comunidade, compartilhando as formas de reprodução social dos grupos sociais característicos daquele território, com isso, é possível ampliar o potencial normatizador da ESF (Nakamura, Gutierres, Cohn, 2009).

Dessa forma, o profissional de saúde ao adentrar no domicílio deve estar munido de um olhar e fazer críticos, para que a VD não se torne apenas um instrumento de controle, com "função disciplinadora das práticas sanitárias" (Morosini, 2007, p.153).

Portanto, embora a VD tenha sofrido reorientações ao longo do processo sócio-histórico da atenção à saúde, desde sua origem mantém o 
enfoque de controle e vigilância, com vistas à prevenção de alguns agravos e dirigida à população pobre adscrita aos serviços de saúde.

A partir de pesquisa anteriormente desenvolvida (Silva, 2012)*, identificou-se possibilidade da VD constituir-se como prática emancipatória. No entanto, na problematização das práticas, observou-se que a VD vem sendo desenvolvidas pelos trabalhadores na perspectiva da clínica. Desse modo, procedeu-se com a revisão de literatura.

\subsection{A VISITA DOMICILIAR NAS PRODUÇÕES CIENTÍFICAS}

Diante das considerações sócio-históricas da VD, buscou-se na revisão da literatura estudos que abordassem essa prática com o intuito de verificar como essa prática vem sendo utilizada nos serviços de saúde na $\mathrm{AB}$, especificamente na ESF.

A busca foi realizada mediante a utilização do descritor visita domiciliar junto ao portal da Biblioteca Virtual em Saúde (BVS). Foram obtidos estudos indexados nas bases de dados: SciELO - Scientific Electronic Library Online, LILACS - Literatura Latino-Americana e do Caribe em Ciências e MedLine, a partir do ano de 1994.

A busca inicial resultou em 552 estudos, a seleção dos artigos de interesse para a revisão seguiu os seguintes critérios de exclusão:

- Trabalhos sem resumo;

- Trabalhos nos quais a VD não fosse o objeto de estudo ou que não tivessem relação ao tema em estudo;

- Trabalhos indisponíveis, na íntegra, na internet ou já selecionados em outra busca;

- Trabalhos que não estivessem relacionados à ESF.

Com a aplicação desses critérios obteve-se o total de 19 artigos, selecionados para compor a revisão.

* Este estudo, assim como Silva (2012), integra o projeto matriz de Campos (2012). 
Apesar de não ser um instrumento exclusivo da prática do enfermeiro, a VD é reconhecida como parte do trabalho do desse e de outros trabalhadores da enfermagem (Egry, Fonseca, 2000).

Essas autoras definiram a VD como o instrumento, dentre os diversos que compõe o arsenal da enfermagem, que apresenta a especificidade de ser "utilizado para intervenção no processo saúde-doença familial, realizada no local de moradia, e não de trabalho ou estudo" (Egry, Fonseca, 2000, p.235). A VD é assinalada com a finalidade de intervenção nos perfis epidemiológicos das famílias e a expansão da consciência crítica acerca das funções sociais da família na sociedade (Egry, Fonseca, 2000), no entanto, não especificam como alcançar essas finalidades.

Para Takahashi e Oliveira (2001), a VD é um instrumento, fundamental na ESF, para conhecer as condições de vida e saúde das famílias, pois permite a identificação in loco tanto de agravos, como das condições de trabalho e vida e aspectos epidemiológicos das famílias, facilitando o planejamento dos cuidados pelo conhecimento dos recursos que o indivíduo e família dispõem. O planejamento e sistematização prévios da VD são relevantes para alinhar o propósito com o qual o profissional vai até o domicílio, pois de outra forma caracteriza-se apenas como uma atividade social (Takahashi, Oliveira, 2001).

Por proporcionar o conhecimento do contexto social do usuário e de suas relações, a VD, de acordo com Borges e D’Oliveira (2011), permite identificar a influencia dessas relações na manifestação do agravo, no entanto, as medidas resolutivas adotadas pelos profissionais voltam-se ao biológico e no âmbito individual.

Sakata et al. (2007) referiram a visita como um acompanhamento em saúde, ora podendo ser interpretada como instrumento para controle da vinculação à longitudinalidade do cuidado; ora para fiscalização e vistoria, relacionada a questões técnicas do serviço e aspectos biológicos do indivíduo, como controle do uso correto da medicação, vacinação e hábitos de vida (Sakata et al., 2007; Sossai, Pinto, 2010). 
Outros autores (Roese, Lopes; 2004) também destacam a VD como como instrumento eficaz na coleta de dados utilizados para vigilância em saúde, a fim de identificar, a partir do contexto domiciliar, o perfil epidemiológico das famílias, e assim, avaliar o impacto das ações do serviço, identificar situações de risco, busca ativa de faltosos e interagir com as pessoas em seu meio.

Azeredo et al. (2007) descrevem a VD também como instrumento para reconhecimento e avaliação das características de habitação e saneamento, considerando que as condições do ambiente em que vivem as famílias estão na base do processo saúde-doença. Sugerem que a VD seja veículo para orientações, visando mudanças de padrões de comportamento e realização de ações voltadas ao meio ambiente, tais como tratamento caseiro da água para consumo, fechamento de caixa d'água, entre outras.

A VD também foi apontada como instrumento do processo de ensinoaprendizagem de futuros profissionais da saúde (Morita et al., 2010; Romanholi, Cyrino, 2012; Valente et al., 2010; Lopes, Saupe, Massaroli, 2008; Roese, Lopes, 2004). Pois, mediante o conhecimento do contexto domiciliar do usuário, possibilita o planejamento da assistência de forma personalizada, pelo diagnóstico clínico de acordo com a realidade dos usuários (Morita et al., 2010; Romanholi, Cyrino, 2012; Valente et al., 2010).

Ademais, fortalece e amplia vínculos e compromissos entre usuário e profissionais, favorecendo a comunicação (Romanholi, Ciryno, 2012), proporciona ao aluno a compreensão do processo saúde-doença contribuindo para formação crítica tanto profissional como pessoal (Morita et al., 2010; Romanholi, Cyrino, 2012).

Embora muitos estudos refiram a VD como instrumento de reconhecimento de necessidades de saúde (Cruz, Bourget, 2010; Eufrásio et al., 2010; Gaíva, Siqueira, 2011; Lopes, Saupe, Massaroli, 2008; Sakata et al., 2007; Santos, Morais, 2011; Sossai, Pinto, 2010; Valente et al., 2010), não foi encontrada, nos estudos analisados, a definição de necessidades de saúde, nem quais foram as necessidades reconhecidas nas VD. 
As ações descritas nesses estudos foram identificadas com o objetivo de mudança de comportamento da população, a fim de alcançar uma melhor qualidade de vida, no entanto, os resultados apontados pelos artigos não descrevem as experiências dos estudantes na efetivação desse aspecto da prática.

Nos artigos que referiam a VD como prática voltada ao atendimento de agravos específicos (Eufrásio et al., 2010; Torres, Roque, Nunes, 2010), foi descrita como instrumento para captar a realidade do indivíduo, favorecendo o reconhecimento de problemas e necessidades de saúde, para diagnóstico precoce de agravos, para fortalecer o vínculo entre profissionais e usuários, para facilitar a adesão às orientações que visam a mudança de comportamento frente ao agravo, para melhorar o autocuidado e a adesão ao tratamento (Eufrásio et al., 2010). Torres, Roque e Nunes (2010) descreveram a VD como instrumento para conhecer a realidade do indivíduo e da família e como essa influencia no tratamento; associada à prática de educação em saúde, mediante uma relação dialógica com o indivíduo, com vistas ao controle de agravos e de possíveis complicações, e para torná-lo mais independente dos serviços de saúde (Torres, Roque, Nunes, 2010).

Santos e Morais (2011) referem a VD como uma possibilidade de ampliação da prática, no sentido de considerar aspectos socioeconômicos dos usuários para desenvolver ações mais exitosas, porém apenas em relação a doença ou agravo.

Há trabalhos que apresentaram a VD da perspectiva de usuários de serviços de saúde, os que recebem a VD (Albuquerque, Bosi, 2009; Mandú et al., 2008). Embora houvesse referência de que para o usuário a realização da VD significava uma forma de atenção igualitária, contraditoriamente também foi expressa a consideração de que a VD era entendida como um privilégio ou favor (Albuquerque, Bosi, 2009).

De acordo com Albuquerque e Bosi (2009) a visita da equipe no domicílio era percebida pelo usuário como via para a garantia de direitos. Além de facilitar o acesso a técnicas de diagnóstico e tratamento, pode 
representar uma porta para o acesso a serviços de maior complexidade tecnológica (Albuquerque, Bosi, 2009; Mandú et al., 2008).

Já os usuários de serviços de saúde do estudo de Albuquerque e Bosi (2009), acreditavam receber as visitas por obrigação ou por determinação do próprio serviço, mas destacaram o apreço pela presença do médico na VD.

Dessa forma, o que prevaleceu nos artigos analisados foi a percepção do usuário de que a VD é valorizada para efetivar o acesso a procedimentos de prevenção ou de tratamento de doenças, realizados na Unidade Básica de Saúde - UBS ou em serviços de maior complexidade tecnológica, que por meio do encaminhamento convencional é mais difícil.

Outro conjunto de trabalhos apresentou a VD da perspectiva dos profissionais de equipes da ESF (Borges, D’Oliveira, 2011; França, Pessoto, Gomes, 2006; Gaíva, Siqueira, 2011; Sakata et al., 2007; Santos, Morais, 2011; Sossai, Pinto, 2010). Estudo de França, Pessoto e Gomes (2006) descreveu que a concepção do enfermeiro sobre a VD esta associada a um instrumento para atendimento e orientação no domicílio, enquanto que para o médico e ACS representa, respectivamente, uma consulta clínica no domicílio e o monitoramento e orientações.

A VD é apontada com potencialidade para constituir-se em instrumento de mudança na interação profissional-paciente no cuidado (Borges, D’Oliveira, 2011). As ações prestadas no domicílio, por caracterizar um espaço diferente do serviço, o espaço do usuário, possibilita ao trabalhador reconhecer as condições de vida e fortalecer o vínculo do usuário com a equipe, ampliando a eficácia dos serviços e a participação do usuário na assistência (Santos, Morais, 2011).

Dessa forma, é possível prestar uma assistência integral, pelo reconhecimento do modo de vida das famílias, refletindo na incorporação dos conhecimentos adquiridos no contato em domicílio, para o planejamento de orientações dirigidas às necessidades de saúde (Borges, D’Oliveira, 2011; Santos, Morais, 2011).

No entanto, o caráter mecanizado e fragmentado das práticas realizadas durante as VD tem dificultado o estabelecimento de vínculos 
(Gaíva, Siqueira, 2011; Santos, Morais, 2011), para que o profissional seja uma referência não apenas para o indivíduo, mas também para a população (Santos, Morais, 2011).

As visitas realizadas pelas enfermeiras tem sido pontualmente restritas a usuários que não podem deslocar-se até a UBS, a indivíduos dos programas pré-definidos pelo MS, considerados grupos prioritários, em determinados momentos do ciclo vital (puérperas, recém-nascidos e idosos), com foco no cuidado e em orientações essenciais para a família. Quando realizada pelo médico, a VD apresenta-se direcionada ao indivíduo doente, não abrangendo a família (Gaíva, Siqueira, 2011; Sossai, Pinto, 2010). A prática da VD ainda é utilizada para cadastramento de novos usuários da USF, para orientações, como veículo de ações de vigilância à saúde e para controle de casos clínicos julgados necessários pela equipe de saúde (Sakata et al., 2007; Sossai, Pinto, 2010).

Aspectos sinalizados pelos trabalhadores como limitantes para a realização da VD foram relacionados: ao tempo escasso, à falta de materiais e dificuldade de capacitação profissional para realização da visita (Gaíva, Siqueira, 2011; Sossai, Pinto, 2010).

Como potencialidades da VD, trabalhadores de equipes de ESF referiram: facilitar a identificação de riscos à saúde dos habitantes sob responsabilidade da equipe, a partir da avaliação dos perfis dessa população; favorecer a diminuição da hospitalização, devido às orientações individualizadas para o autocuidado e as mudanças de comportamento; e a redução do número de atendimentos na UBS, pela sua realização no domicílio (Sossai, Pinto, 2010).

Assim, por meio da revisão dos artigos em bases de dados da área da saúde é possível afirmar que ao longo do processo histórico-social do cuidado à saúde, de indivíduos ou de populações, a VD não sofreu mudanças em sua essência, a não ser ter sido incorporada de um estatuto científico, na medida em que é realizada por trabalhadores com formação especializada na área da saúde. Nesse contexto, a VD continua predominantemente guiada pelo objetivo que deu origem a essa prática - o 
controle de comportamento e hábitos, sob o discurso que vem da área da saúde - a prevenção, o tratamento e o controle de agravos .

Nas origens da VD as doenças priorizadas eram as transmissíveis, características da urbanização desordenada e da precarização das condições de trabalho e de vida dos trabalhadores, que estavam nas bases do modo de produção capitalista em ascensão. Portanto, as ações de controle preconizadas na VD eram as voltadas a hábitos de higiene, no domicílio ou no ambiente público.

Em tempos de ESF o foco são as doenças crônicas não transmissíveis, como a hipertensão e o diabetes, características dos padrões de trabalho e de consumo contemporâneos, e o monitoramento de processos característicos de etapas do ciclo vital. As ações de controle preconizadas na VD são voltadas aos chamados hábitos saudáveis (realizar atividade física, não fumar ou ingerir álcool, alimentar-se segundo regras que oscilam em função de interesses dominantes), com vistas a que o indivíduo, para que tenha boas condições de saúde, atinja um atributo abstrato - qualidade de vida - que fica sob a responsabilidade e depende do emprenho individual. 
2 Cansideraçães teáricas 


\section{CONSIDERAÇÕES TEÓRICAS}

Ancorado no arcabouço teórico-metodológico marxista, também conhecido como materialismo histórico e dialético, que esteve nas bases da constituição do campo da Saúde Coletiva, este estudo partiu da compreensão que os fenômenos presentes na realidade não são naturais, são socialmente produzidos, e que a transformação de um aspecto desse dado fenômeno é possível a partir da apreensão, no plano da consciência, da relação entre a parte (o aspecto do fenômeno em análise) e o todo que conformam esse fenômeno (Soares, Campos, Yonekura, 2013).

Portanto, este estudo tomou por base os conceitos da Saúde Coletiva. Adotou a categoria analítica necessidades, para compreender o objeto do trabalho dos enfermeiros, as necessidades de saúde - que são socialmente determinadas, e a categoria analítica processo de trabalho em saúde para compreender as práticas dos enfermeiros.

\subsection{TRABALHO E PROCESSO DE TRABALHO}

Neste estudo, considera-se prática como trabalho, que é a essência da sociabilidade humana.

\footnotetext{
"Sem dúvida, a substância do existir é a prática. Não é a expressão teórica, em si mesma, que efetiva nossa existência real. Só se é algo mediante um contínuo processo de agir, só se é algo mediante a ação. É o que testemunham todos os entes que se revelam à experiência humana. É na e pela prática que as coisas humanas efetivamente acontecem, que a história se faz e que o próprio homem vai se fazendo humano" (Severino, 1998, p.12).
}

Trabalho é compreendido como

"um processo de que participam o homem e a natureza, processo em que o ser humano com sua própria ação, impulsiona, regula e controla seu intercâmbio material com a natureza. (...) Põe em movimento as forças naturais de seu corpo, braços e pernas, cabeça e mãos, a fim de apropriar-se dos recursos da natureza, imprimindo-lhes forma útil à vida humana" (Marx, 1980, p.202). 
Para Severino (1998, p. 12), o trabalho é a esfera básica da subsistência humana, "já que a vida depende radicalmente dessa troca entre o organismo e a natureza física".

Esse processo de interação com a natureza não ocorre de maneira instintiva, mas a partir de uma projeção mental previamente intencionalizada que antecede a transformação do objeto. Ou seja, o trabalho não se dá apenas com a transformação aleatória do objeto, o trabalhador "imprime ao material o projeto que tinha conscientemente em mira” (Marx, 1980, p.202).

Para concretizar a subjetivação que deu origem ao processo de trabalho, Marx descreve três elementos envolvidos: o trabalho propriamente dito; o objeto de trabalho e; os meios ou instrumentos para transformar o objeto (Marx, 1980). Os quais serão articulados em consonância com a finalidade que rege o processo de trabalho.

$\mathrm{O}$ instrumento de trabalho ou o meio de trabalho, corresponde a "uma coisa ou um complexo de coisas que o trabalhador insere entre si mesmo e o objeto de trabalho e lhe serve para dirigir sua atividade sobre esse objeto" (Marx, 1980, p.203), possibilitando a transformação do objeto em produto.

Aquilo que será transformado em um produto que atenda a necessidade instauradora do processo de trabalho corresponde ao objeto. $\mathrm{O}$ produto resultante, a depender de sua função no processo de trabalho, pode ser destinado a responder a uma necessidade humana, findando-se como valor-de-uso; pode servir como matéria-prima para transformação de novos produtos; ou pode ser utilizado como instrumento para atuar sob outro objeto de trabalho (Marx, 1980).

Assim, o processo de trabalho tem a finalidade de criar valores-deuso, ou seja, de fazer com que o homem se aproprie da natureza, transformando-a mediante a impressão do projeto idealizado mentalmente, para atender necessidades humanas (Marx, 1980).

Desse modo, "a atividade do homem opera uma transformação, subordinada a um determinado fim, no objeto sobre que atua por meio do instrumental de trabalho. O processo extingue-se ao concluir-se o produto" 
(Marx, 1980, p.205). Ou seja, para responder a necessidade que originou o processo de trabalho, o homem utiliza instrumentos ou meios de trabalho para agir sob o objeto, com a finalidade de transformá-lo em um produto que atenda a necessidade instauradora do processo de trabalho.

\subsection{PROCESSO DE TRABALHO EM SAÚDE E EM ENFERMAGEM}

O processo de trabalho contém características sócio-históricas, e “antes que o processo comece, necessariamente alguma forma de relação estará estabelecida entre os homens e as condições da produção" (Gonçalves, 1992, p.16).

As transformações na estrutura social com a consolidação do capitalismo, suscitaram a reorganização das relações sociais entre os homens, que passou a ser mediada pelo trabalho; com isso, novas necessidades sociais de saúde* foram instauradas (Gonçalves, 1992).

Portanto, o processo de produção em saúde está submetido às mesmas ordenações de outros processos de produção do modo de produção capitalista. No entanto, adquire a conotação de trabalho nobre, tanto pela valoração social positiva da dimensão intelectual em detrimento da manual; pela associação ideológica dos valores atribuídos ao objeto do processo - a saúde, um bem precioso que não se finda como um produto material para ser consumido; e pela posição social obtida e reproduzida pelos agentes do trabalho (Gonçalves, 1992).

Da mesma forma que em processos de produção de mercadorias materiais, na saúde também a fragmentação do objeto possibilita o aumento da produção de produtos, por meio da fragmentação do trabalho. Com essa organização, cada trabalhador pode realizar uma parcela do trabalho todo, dominando apenas uma parte do conjunto de instrumentos, que incidirá em parte do objeto. O trabalho pode ser realizado mesmo sem que o trabalhador conheça a finalidade do processo como um todo (Gonçalves, 1992).

* Por necessidades sociais, compreende-se necessidades da sociedade eleitas para representar o todo a partir de interesses do grupo dominante (Gonçalves, 1992). 
Essa divisão da atividade em partes tem a aparência de ser determinada apenas por características técnicas, uma divisão de tarefas. No entanto, traz subliminarmente outra divisão, a divisão social. Na sociedade a divisão e a valoração entre o trabalho intelectual e o braçal são desiguais; sendo a parcela do trabalho intelectual realizada por sujeitos das classes com maior acesso a bens, aos processos de formação, opostamente às classes que se inserem na parcela mais manual do trabalho (Gonçalves, 1992).

Essa divisão se expressa como divisão técnica, mas é sobredeterminada pela divisão social (Viana, Soares, Campos, 2013).

Como decorrência, aos agentes da enfermagem, ao tornar-se trabalho em saúde, coube a parcela manual, menos valorizada, e aos médicos coube o domínio do processo, por dominar a parcela intelectual do trabalho - o diagnóstico e a prescrição (Gonçalves, 1992).

Assim, para desempenhar a parte manual do trabalho médico, ficando subordinada aos conhecimentos dessa categoria, ocorreu a profissionalização da enfermagem como uma prática social * (Almeida, Rocha, 1989; Silva, 1989).

As atividades práticas, orientadas por um saber técnico pautado na realização de tarefas e procedimentos, destinavam-se à execução de tarefas, (Almeida, Rocha, 1989), numa lógica marcadamente como expressão do capitalismo, em que "a maior parte dos objetos do trabalho passarão a ser, com o aprofundamento da divisão do trabalho, objetos artificiais, produtos de outros processos de trabalho" (Gonçalves, 1992, p.41).

Desse modo, o processo de trabalho em saúde já tem um recorte prévio do objeto. No âmbito do processo de trabalho do enfermeiro, este

* Uma prática social é constituída no decorrer de um processo sócio-histórico, mediante o reconhecimento social de suas ações de cuidado e o modo como os trabalhadores se relacionam e se inserem no mundo do trabalho (Peduzzi, Silva, Lima, 2013; Silva, 1989; Trezza, Santos, Leite, 2008).

Estabelece relações com outras profissões, com as dimensões política, econômica, cultural e social das instâncias que compõem a estrutura de uma sociedade (Trezza, Santos, Leite, 2008). Configura-se como uma teia de relações sociais, contribuindo para conformação de outras práticas sociais. Inserida em um contexto sócio histórico, sobre o qual interfere e sofre interferências, não é neutra, conforma-se nesse processo ao mesmo tempo que influencia sua conformação (Pereira et al, 2009). 
entra como um instrumento do processo de trabalho em saúde, que incide em fragmentos já recortados do objeto.

É a concepção do processo saúde-doença que permite "destacar e recortar, com conjunto do fenômeno saúde e doença, o que se constituirá em objeto de trabalho ou de intervenção profissional" (Peduzzi, Silva, Lima, 2013, p.225).

Utilizando-se do convencimento ideológico nos âmbitos político (igualdade) e econômico (liberdade), o processo de trabalho em saúde assumiu o projeto capitalista, com práticas voltadas ao controle da “ocorrência de escassez de trabalho" (Gonçalves, 1992, p.35).

Para efetivar a manutenção de corpos minimamente saudáveis para a reprodução do novo modo de produção, dois modelos de práticas são adotados, o da epidemiologia e o da clínica, voltadas para responder necessidades sociais, as do modo de produção, acima das necessidades do conjunto da população (Gonçalves, 1992).

Com a finalidade de controlar a ocorrência de doenças, o modelo epidemiológico utilizou-se da concepção da doença como fenômeno coletivo, relacionando-a com as condições de tempo, espaço, do doente e do ambiente. Nessa perspectiva, com os instrumentais disponíveis na época, conhecimentos geográficos e matemáticos, era possível prever a quantidade de novos casos e verificar a relação entre doença e ambiente, para a diminuição ou estabilização de novos casos por meio de ações de saneamento ambiental e de educação em saúde (Gonçalves, 1992).

Ao considerar a concepção de doença como fenômeno coletivo, esse modelo apresenta contradições que implicariam em consequências políticas, a depender da perspectiva que recorte o objeto. Por exemplo, a concepção de doença como fenômeno natural, que incide sobre um conjunto homogêneo de indivíduos era muito mais interessante que considerá-la essencialmente social, o que implicaria em mudanças na estrutura social para responder necessidades de saúde (Gonçalves, 1992).

O modelo da clínica, com seu auge no século XX, a partir do desenvolvimento da fisiologia, patologia, farmacologia e técnicas cirúrgicas, 
tem por finalidade recuperar a força de trabalho incapacitada pela doença, recortando a doença como mera alteração do funcionamento do corpo humano, considerando-o como corpo biológico de um sujeito abstrato. (Gonçalves, 1992).

Para Gonçalves (1992), esse foi o modelo da clínica que alcançou hegemonia, por se compor perfeitamente com o projeto politico-ideológico do capitalismo.

Ao mesmo tempo permite tornar o produto do processo de trabalho em um bem consumível individualmente, tal como qualquer mercadoria, tornando-o importante peça nas negociações dos conflitos sociais e fragmentar o corpo como um objeto natural que prescinde do âmbito social. Ou seja, o conhecimento da clínica vai ao encontro do ideário do modo de produção capitalista.

Com a compreensão de que todo processo de trabalho é originado para responder a uma necessidade, que por sua vez é a disparadora do processo de trabalho, há uma consubstancialidade e circularidade entre processos de trabalho em saúde e necessidades de saúde (Gonçalves, 1992).

\subsection{NECESSIDADES DE SAÚDE E DETERMINAÇÃO SOCIAL DO PROCESSO SAÚDE-DOENÇA}

As necessidades que movimentam o processo de trabalho nunca são naturais, mas específicas em conteúdo e forma a um determinado contexto sócio-histórico, portanto, serão satisfeitas por determinados produtos que devem ser necessariamente consumidos, para que os sujeitos se reproduzam enquanto ser social (Gonçalves, 1992).

Neste trabalho, necessidades de saúde são compreendidas como necessidades de reprodução social, ou seja, aquelas que garantem a continuação da vida dos seres sociais, ou a reprodução das classes sociais (Gonçalves, 1992). Portanto, necessidades de saúde são geradas a partir das relações estabelecidas entre os seres humanos para se reproduzirem como sujeitos e como sociedade (Campos, Soares, 2013). 
Por perfis de reprodução social entende-se,

\begin{abstract}
o conjunto da vida social caracterizado pelas formas de trabalhar e consumir, pelas relações que os seres humanos estabelecem entre si para produzir a vida social, pela forma em que transformam a natureza, pela forma em que realizam a distribuição e o intercâmbio dos bens socialmente produzidos, pelas instituições que geram e pelo nível de consciência e organização que alcançam (Campaña, 1997, p.133).
\end{abstract}

Uma vez que, as classes sociais são heterogêneas, pois são compostas por sujeitos com desiguais inserções sociais (Trapé, 2011), as necessidades de saúde também serão heterogêneas (Gonçalves, 1992). Dito de outra forma, as necessidades de saúde são heterogêneas porque são desiguais e heterogêneos os perfis de reprodução social. Esses perfis de reprodução social, expressos no corpo biopsíquico dos sujeitos, determinam os perfis saúde-doença (Campaña, 1997).

Nessa perspectiva teórica, o modo como os sujeitos das diferentes classes sociais se inserem nas condições de trabalho orienta suas formas de viver, determinando diferentes processos saúde-doença (Viana, Soares, Campos, 2013).

Portanto, compreende-se que os gradientes de saúde-doença expressos no corpo dos indivíduos são socialmente determinados e correspondem ao resultado do embate entre potenciais de fortalecimento e de desgaste a que estão submetidos. Esses gradientes expressam-se desigualmente no corpo biopsíquico dos indivíduos das diferentes classes sociais porque são desiguais os acessos a aqueles potenciais, desigualdade essa determinada pelas heterogêneas características de inserção dos grupos nas condições de reprodução social. Quanto mais acesso a potenciais de fortalecimento, maior é o gradiente de condições de saúde; consequentemente, quanto mais exposto a potenciais de desgaste, maior será o gradiente de condições danosas à saúde (Salum, Queiroz, 2009; Viana, Soares, Campos, 2013).

$\mathrm{Na}$ sociedade de classes, as necessidades sempre foram expressas pelas necessidades das classes dominantes. No capitalismo, o processo saúde-doença está centrado apenas nos aspectos biológicos, 
desconsiderando a determinação social desse processo (Gonçalves, 1992). Laurell (1983, p.148:149) reitera que

"o conceito de doença oculta, quer dizer, que está
subjacente na definição social do que é doença, refere-
se à incapacidade de trabalhar, o que a coloca em
relação com a economia e eventualmente com a criação
da mais-valia e possibilidade de acumulação
capitalista" (Laurell, 1983, p.148:149).

Ao conceber o processo saúde-doença como natural, como parte da natureza humana, mantem-se o status quo da estrutura social; do contrário, ao considerar a determinação social do processo saúde-doença, seria necessário mudanças na estrutura da sociedade para produzir saúde (Gonçalves, 1992).

Assim, uma vez que "necessidades de saúde são necessidades impostas pela vida social, ou seja, são necessidades de reprodução social e não se restringem à necessidade de serviços de saúde" (Campos, 2009: 155), devem ser identificadas no conjunto da vida social.

Com essa compreensão, necessidades de saúde são definidas por Campos (2009) como: necessidades de reprodução social, que constituem a base do processo saúde-doença, que para serem aprimoradas em sua complexidade demandam a necessidade da presença do Estado, para a garantia e o acesso a direitos universais, que será tanto mais presente quanto maior a participação social dos sujeitos, possibilitando "a discussão e o embate das necessidades e dos interesses das classes sociais e dos grupos organizados da sociedade civil" (Campos, 2009, p.155).

O reconhecimento de necessidades de saúde ocorre por meio de indicadores que identifiquem e caracterizem essas necessidades em cada um de seus âmbitos.

Nas condições de reprodução social, caracterizadas "pelas formas de trabalhar e consumir" (Campaña, 1997, p.133), os indicadores devem apreender a heterogeneidade das condições de reprodução social, identificando as formas de trabalhar dos chefes das famílias (curso preparatório para o trabalho e qualificação da ocupação) e condições materiais de vida das famílias (propriedade da residência, número de 
cômodos para dormir, recebimento de IPTU, de contas de água e luz, acesso a serviço público de esgoto e frequência a cultos religiosos como forma de lazer) (Trapé, 2011).

Esses indicadores também refletirão a presença do Estado no território, associados à “distribuição e (...) intercâmbio dos bens socialmente produzidos [e] pelas instituições que geram” (Campaña, 1997, p. 133). A identificação das características relativas à estrutura do bairro (saneamento básico, pavimentação, sinalização e iluminação das ruas, áreas de risco, entre outras); da presença das instituições sociais no território (escolas, creches, centros de convivência, parques, serviços de saúde, ONGs, entre outras) permite a apreensão das necessidades atinentes a presença do Estado (Campos, 2009).

Os indicadores capazes de apreender a participação social dos sujeitos, identificada como o "nível de consciência e organização que [os sujeitos] alcançam" (Campaña, 1997, p. 133); fazem referencia a organização que os moradores alcançam. Estão relacionados às características da participação em instâncias que favorecem a organização popular (movimentos sociais, associações, conselhos gestores, agremiações, cooperativas, sindicatos, partidos políticos, entre outras formas de participação social) (Campos, 2009).

Portanto, os processos de trabalho em saúde que pretendam aprimorar necessidades de saúde não podem restringir-se a procedimentos oferecidos por serviços de saúde, incidentes exclusivamente num recorte do corpo biopsíquico individual - a disfunção.

Advoga-se que se configurem como práticas emancipatórias, que são as que:

possibilitam a reflexão sobre a origem dos problemas de saúde, dos determinantes do processo saúde-doença, mediante a instrumentalização dos sujeitos para acessar seus direitos e lutar por eles, incentivam valores de solidariedade e resgatam a condição humana como condição social, em contraposição ao sujeito como ser biológico (Campos, 2013: 70) 
Diante do exposto, partiu-se do pressuposto que as práticas de saúde são orientadas por políticas públicas de saúde, e assim como desenvolvem ações que reiteram necessidades de saúde como demanda de serviços de saúde, podem ser instauradoras de necessidades de saúde com respostas direcionadas as condições de reprodução social. 
3 Finalidade e abjetivas 


\section{FINALIDADE E OBJETIVOS}

\subsection{FINALIDADE}

Contribuir para o aprimoramento das práticas do enfermeiro na Atenção Básica.

\subsection{OBJETIVO GERAL}

Apresentar a VD como prática emancipatória na $\mathrm{AB}$.

\subsection{OBJETIVOS ESPECÍFICOS}

- Identificar as práticas em saúde como instrumentos do processo de produção em saúde;

- Apreender as dimensões teórico-metodológicas que embasam as práticas emancipatórias em saúde;

- Elaborar um roteiro de VD como prática emancipatória em saúde. 
4 Pracedimentas metadalágicas 


\section{PROCEDIMENTOS METODOLÓGICOS}

\subsection{TIPO DE PESQUISA}

Esta pesquisa configura-se como pesquisa qualitativa, coerentemente ao arcabouço teórico do materialismo histórico e dialético e com o caráter social do objeto em questão, a VD.

Neste estudo, optou-se pela abordagem metodológica da PesquisaAção (P-A) emancipatória, uma vez que, compreende-se que os fenômenos não são abstratos e inertes na realidade, mas sim, que são determinados pelas relações sociais associadas ao modo de organização da estrutura social.

O processo educativo foi desenvolvido mediante oficinas emancipatórias, um importante instrumento do processo de aprimoramento das práticas. Com potencialidade para ampliar o conhecimento dos sujeitos, em um processo que traz o indivíduo como autor da ação, por meio da participação crítica, e que valoriza os saberes oriundos da prática sobre o fenômeno abordado (Chiesa, Westphal, 1995).

A principal característica das oficinas está na possibilidade de proporcionar um espaço de reflexão sobre a práxis. Sendo a educação fonte instrumentalizadora da práxis criativa, considera-se a oficina "um instrumento potente para que os sujeitos - agentes e coprodutores do processo educativo participem com a finalidade de transformar a práxis reiterativa em práxis criativa" (Soares et al., 2009, p.192).

Nesse sentido, a P-A emancipatória converge com a finalidade deste trabalho, pois "não se limita a uma forma de ação, pretende-se aumentar o conhecimento dos pesquisadores e o conhecimento ou 'nível de consciência' das pessoas e grupos considerados" (Thiollent, 2011, p. 23). Assim, não se limita a desenvolver uma ação por si só, que se finda nela mesma, possibilita o desenvolvimento dos sujeitos de "dentro para fora" (Engel, 2000). Ou seja, busca a transformação da práxis social pela mediação do conhecimento teórico, alcançando a "politização dos sujeitos 
envolvidos, que passam a ter condições de desenvolver práxis criativas e emancipatórias" (Soares, Cordeiro, 2013, p. A173).

\subsubsection{Da Pesquisa-Ação e Pesquisa-Ação Emancipatória}

Desde sua origem na década de 1940, nos trabalhos de Kurt Lewin, a P-A tem sido utilizada de distintas maneiras, a partir da finalidade almejada pelo pesquisador (Franco, 2005; Silva, Morais, Figueiredo et al., 2011; Thiollent, 2011; Tripp, 2005). Devido ao caráter que articula pesquisa e prática, não tardou para que a P-A começasse a ser utilizada na otimização de práticas nas áreas técnico-organizacionais (Franco, 2005; Thiollent, 2011).

Apoiando-se no positivismo, as dimensões que integravam a proposta de Lewin dividiram-se em quatro tipos de P-A: diagnóstica; participante; empírica e experimental. Na década de 1980, com a incorporação de fundamentos da teoria crítica, a P-A assumiu a perspectiva dialética para alcançar a melhoria da prática (Franco, 2005).

A P-A desenvolve-se em "um processo integrador entre pesquisa, reflexão e ação" (Franco, 2005, p. 493), por meio da retomada constante das fases de planejamento, implementação, descrição e avaliação, dispostas em espirais cíclicas durante todo o processo (Tripp, 2005).

A diversidade de utilizações da P-A conforma o que Franco (2005, p. 485) denominou de "mosaico de abordagens teórico-metodológicas". Tripp (2005) cita a variação na utilização das fases do ciclo básico de toda investigação-ação, e a consequente diversidade na obtenção dos resultados, como motivos para a variedade desse tipo de pesquisa.

A divulgação dos resultados da P-A, geralmente voltada para seus pares e restringindo-se à sua área de conhecimento, dificulta a difusão dessa modalidade de pesquisa (Thiollent, 2011), situação reiterada na literatura brasileira pela ausência do termo "pesquisa-ação" como um descritor cadastrado na Biblioteca Virtual de Saúde (BVS) (Silva, Morais, Figueiredo, et al., 2011). 
Desse modo, é preciso esclarecer de qual pesquisa e ação estamos falando. Diferentemente do que alguns pesquisadores consideram, a P-A não corresponde a uma ação pesquisada, em que o conhecimento científico resultante da ação é valorizado em detrimento do aprimoramento da prática (Tripp, 2005). De acordo com Franco (2005, p.497), o hífen entre as palavras pesquisa e ação deveria ser substituído por uma flecha de duplo sentido, sugerindo que é pesquisa com ação e ação com pesquisa; ou seja, há "concomitância, intercomunicação e interfecundidade" entre ambas, com integração dialética entre teoria e prática, fatos e valores, cientificidade e empirismo, pesquisador e pesquisado.

Apesar de abordar prática e pesquisa, a P-A se distingue de ambas, pois "ao mesmo tempo altera o que esta sendo pesquisado e é limitada pelo contexto e pela ética da prática" (Tripp, 2005, p. 447). Mantém distância da prática cotidiana enquanto hábito ou rotina e das limitações da pesquisa tradicional, destacando-se a flexibilidade metodológica como elemento essencial da P-A, sem que haja uma rigidez de fases para o desenvolvimento do processo de melhoramento da prática, visto que não tende à generalização dos resultados. Porém, por se tratar de um tipo de pesquisa, segue um rigor epistemológico (Franco, 2005; Tripp, 2005).

Nessa perspectiva, Tripp (2005) considera a P-A o elo de transição para a articulação entre teoria e prática, separadas pelo objetivismo e racionalidade positivistas. Essa articulação ocorre para uma intervenção social na prática, sendo essa intervenção a origem do processo e seu fim, sempre mediada pelos fundamentos teóricos que impulsionam e sustentam a reflexão e criticidade sobre a práxis, pois o ponto de partida e chegada da crítica é a prática, que é a efetivação da teoria (Miranda, Resende, 2006).

A P-A propõe, a partir da identificação de uma situação que pode ser melhorada, um processo de intervenção com a intenção de transformar a prática e, para que isso ocorra, é imprescindível compreender o problema e identificar sua origem antes de propor a mudança (Engel, 2000; Franco, 2005; Miranda e Resende, 2006; Tripp, 2005). 
$\mathrm{Na}$ modalidade de P-A de caráter socialmente crítico, a problematização de uma situação problema "geralmente se inicia com um exame sobre a quem cabe o problema" (Tripp, 2005).

A identificação do problema e a formulação de soluções exigem um processo participativo e colaborativo entre pesquisadores e participantes para que, atuando deliberativamente durante o processo, as transformações da prática alcancem a todos os envolvidos (Franco, 2005; Thiollent, 2011; Tripp, 2005).

O pesquisador assume um papel de mediador e facilitador da decodificação do conhecimento científico, na formação de sujeitos ativos na transformação da prática (Franco, 2005; Thiollent, 2011; Tripp, 2005). Esse papel ativo dos participantes na P-A difere das pesquisas tradicionais, em que ocorre apenas o levantamento de informações, que se limitam ao meio acadêmico ou burocrático, sem um retorno efetivo para a práxis (Thiollent, 2011). Por seu caráter crítico destaca-se junto a grupos socialmente excluídos, na orientação de ação emancipatória, por meio da construção coletiva do conhecimento a partir de um problema da realidade dos próprios sujeitos (Thiollent, 2011; Toledo, Giatti, Pelicioni, 2012).

A aplicação da P-A pode abranger variados campos de observação, desde uma comunidade, instituições ou pequenos grupos. O tamanho do grupo, assim como em outros tipos de pesquisa, é geralmente determinado pelo que Thiollent (2011) denomina de "amostras intencionais", na qual os participantes são escolhidos devido à importância da contribuição de seu papel social na situação apontada.

Nessa perspectiva, Toledo, Giatti e Pelicioni (2012) descreveram pesquisa ação para mobilização social de indivíduos de uma comunidade indígena. Os autores citaram que além do envolvimento da população para uma ação pontual identificada, houve maior posicionamento político da comunidade, possibilitando o diálogo com instituições governamentais para responder às necessidades da população.

Já o estudo desenvolvido em hospital, junto a trabalhadores de saúde, destacou inquietações atinentes a questões relacionadas ao processo de 
trabalho deles, orientado pelo modelo biomédico, com práticas voltadas à doença, não ao sujeito e suas necessidades. Os autores ressaltaram a validade desse tipo de pesquisa na promoção de reflexões coletivas nos serviços, para o "reconhecimento das condições sociais, de direitos humanos e de justiça social dos envolvidos", tanto para melhorar a prática como para gerar relações sociais solidárias e resistentes à mercadorização característica das relações estabelecidas na cultura capitalista (DantasBerger, Giffin, 2011, p. 402).

Destaca-se que as características do pesquisador - formação, experiências anteriores, concepções e aprofundamento da situação investigada - têm influencia no processo, marcando a cientificidade e não neutralidade da pesquisa (Franco, 2005; Pessoa, et al., 2013; Thiollent, 2011; Tripp, 2005).

A modalidade de P-A emancipatória busca alcançar a transformação da realidade social, mediante processo que "valoriza a construção cognitiva da experiência, sustentada por reflexão crítica coletiva, com vistas à emancipação dos sujeitos e das condições que o coletivo considera opressivas" (Franco, 2005, p.485), a partir da exposição dos problemas na realidade concreta, para transformar a práxis social (Cordeiro, Soares, Campos, 2013).

Desse modo, a P-A emancipatória converge com a finalidade deste estudo, ao aliar "a exposição do objeto ou fenômeno de interesse aos processos de transformação da realidade, mediado pela crítica que o processo educativo incentiva" (Cordeiro, Soares, Campos, 2013, p. 115).

Para Cordeiro, Soares e Campos (2013) e Soares, Cordeiro e Campos (2013) a P-A emancipatória corresponde a um processo educativo, desenvolvido em cinco etapas.

Nesta pesquisa, foram seguidas as etapas de P-A emancipatória propostas por Cordeiro, Soares e Campos (2013, p.107):

1) reconhecimento de uma dada prática social; 2) problematização da realidade que contextualiza a prática problematizada; 3) instrumentalização dos sujeitos envolvidos no processo educativo, em função das necessidades levantadas para a compreensão da 
prática social problematizada; 4) catarse, que significa incorporação do conhecimento, ou seja, percepção abstrata do que está na dimensão concreta; 5) elaboração e desenvolvimento de novas práticas sociais (Cordeiro, Soares, Campos, 2013, p.107).

Para a apreensão dos conceitos da Saúde Coletiva que ancoram este estudo, propôs-se oficinas emancipatórias, que culminaram na elaboração conjunta de um roteiro de VD emancipatória, que será concretizado em material audiovisual com finalidade pedagógica.

\subsection{LOCAL DO ESTUDO}

A proposta inicial foi a realização de oficinas com enfermeiras trabalhadoras de Unidades de Saúde da Supervisão Técnica de Saúde (STS) Butantã, pela articulação existente entre a Secretaria Municipal da Saúde de São Paulo, representada pelos serviços da $\mathrm{AB}$ da Coordenadoria de Saúde Centro-Oeste (CRS CO), e a Universidade de São Paulo (USP), representada por cursos da área da saúde, dentre eles o da Escola de Enfermagem.

A CRS CO é uma das cinco Coordenadorias de Saúde do município de São Paulo e é composta por três STS: Butantã, Lapa/Pinheiros e Sé. Dispõe de 102 estabelecimentos de saúde, dos quais 35 são Unidades Básicas de Saúde (UBS), sendo 13 na STS Butantã, 14 na STS Lapa/Pinheiros e 8 na STS Sé (São Paulo, 2013)*.

Na apresentação do projeto de realização das oficinas às UBS da STS do Butantã, no entanto, deparou-se com a dificuldade de participação das enfermeiras e por isso optou-se pela ampliação do convite a enfermeiras das demais STS da CRS CO - Sé e Lapa/Pinheiros.

$\mathrm{O}$ convite às enfermeiras foi feito por intermédio da enfermeira responsável, na STS, pela articulação do trabalho de enfermagem.

* São Paulo. Secretaria Municipal de Saúde. Coordenação de Epidemiologia e Inforação CEInfo. Relação dos estabelecimentos/serviços da Secretaria Municipal da Saúde por Coordenadoria Regional de Saúde e Supervisão Técnica de Saúde do Município de São Paulo. http://www.prefeitura.sp.gov.br/cidade/secretarias/upload/saude/arquivos/organi zacao/Unid_Munic_Saude_Subp.pdf 


\subsection{PARTICIPANTES DO ESTUDO}

Uma vez que a VD é um instrumento da prática do enfermeiro na Atenção Básica, essa foi a população de escolha para participar das oficinas. Como critério de inclusão as participantes deveriam atuar na $\mathrm{AB}$ e aceitar participar da pesquisa, mediante assinatura do Termo de Consentimento Livre e Esclarecido.

Dessa forma, as oficinas começaram com a participação de 12 , mas foram presença constante, até o final do processo, 8 enfermeiras, de distintas STS da CRS Centro-Oeste, caracterizadas no Quadro 1.

Para garantir o sigilo, as participantes foram identificadas pela letra "E”, seguida por um número de 1 a 12.

Quadro 1 - Caracterização das enfermeiras participantes da pesquisa. São Paulo, 2013

\begin{tabular}{|c|c|c|c|c|c|c|}
\hline & $\begin{array}{l}\text { Idade } \\
\text { (anos) }\end{array}$ & Formação profissional & $\begin{array}{l}\text { Tempo } \\
\text { (anos) }\end{array}$ & $\begin{array}{l}\text { Local de } \\
\text { atuação }\end{array}$ & Cargo & $\begin{array}{l}\text { Tempo } \\
\text { na AB } \\
\text { (anos) }\end{array}$ \\
\hline E1 & 38 & Bacharelado & 7 & CAPS & RT & 6 \\
\hline E2 & 35 & $\begin{array}{l}\text { Bacharelo e } \\
\text { Licenciatura; } \\
\text { Especialização; } \\
\text { Mestrado; } \\
\text { Doutorado }\end{array}$ & 12 & $\begin{array}{l}\text { US Boa } \\
\text { Vista }\end{array}$ & Enf. de SF & 5 \\
\hline E3 & 26 & $\begin{array}{l}\text { Bacharelado; } \\
\text { Especialização }\end{array}$ & 5 & $\begin{array}{l}\text { US Jd } \\
\text { D'Abril }\end{array}$ & $\begin{array}{l}\text { Enfermeira de } \\
\text { SF }\end{array}$ & 4 \\
\hline E4 & 28 & \begin{tabular}{|l|} 
Bacharelado e \\
Licenciatura; \\
Especialização \\
\end{tabular} & 7 & $\begin{array}{l}\text { UAD } \\
\text { Butantã }\end{array}$ & Enfermeira & 5 \\
\hline E5 & 51 & $\begin{array}{l}\text { Bacharelado; } \\
\text { Especialização; } \\
\text { Mestrado; } \\
\text { Doutorado }\end{array}$ & 28 & $\begin{array}{l}\text { STS } \\
\text { Butantã }\end{array}$ & Assessoria & 5 \\
\hline E6 & 50 & $\begin{array}{l}\text { Bacharelado; } \\
\text { Especialização; } \\
\text { Mestrado profissional } \\
\text { (em andamento) }\end{array}$ & 8 & $\begin{array}{l}\text { CSE } \\
\text { Butantã }\end{array}$ & $\begin{array}{l}\text { Enfermeira e } \\
\text { Docente }\end{array}$ & 26 \\
\hline E7 & 50 & $\begin{array}{l}\text { Bacharelado; } \\
\text { Mestrado }\end{array}$ & 29 & $\begin{array}{l}\text { CSE } \\
\text { Butantã }\end{array}$ & $\begin{array}{l}\text { Coordenadora } \\
\text { de } \\
\text { Enfermagem } \\
\end{array}$ & 11 \\
\hline E8 & 44 & $\begin{array}{l}\text { Bacharelado e } \\
\text { Licenciatura; } \\
\text { Habilitação em Saúde } \\
\text { Pública; Especialização; } \\
\text { Mestrado; Doutorado } \\
\text { (em andamento) } \\
\end{array}$ & 22 & STS Sé & $\begin{array}{l}\text { Interlocução de } \\
\text { enfermagem e } \\
\text { docente }\end{array}$ & 10 \\
\hline
\end{tabular}




\subsection{CAPTAÇÃO DE MATERIAL INFORMATIVO}

A captação do material informativo foi realizada nas oficinas emancipatórias, em que se discutiu processo de trabalho e seus elementos constitutivos, necessidades de saúde, políticas de saúde e as práticas de enfermagem, objetivando promover a reflexão sobre as práticas de saúde e de enfermagem. O processo culminou com a elaboração conjunta de um roteiro de VD emancipatória.

Posteriormente esse roteiro será transformado em material áudio visual, gravado com as enfermeiras participantes das oficinas. Esse material terá finalidade pedagógica, servirá como apoio na formação de futuros trabalhadores da saúde, na universidade, e em processos de aprimoramento do trabalho de trabalhadores de serviços de saúde.

\subsubsection{Oficinas emancipatórias}

No início do processo educativo, contemplando a etapa de instrumentalização dos sujeitos, foram desenvolvidas oficinas emancipatórias junto a enfermeiras da $\mathrm{AB}$. Esses encontros ocorreram quinzenalmente, em serviço de saúde da STS Butantã, no período de outubro a dezembro de 2013. Essa parte inicial totalizou sete encontros, com tempo médio de 3 horas de duração.

Todas as oficinas foram áudio gravadas e posteriormente transcritas na íntegra.

O processo conjunto de instrumentalização das enfermeiras foi ancorado nos conceitos da Saúde Coletiva, com a compreensão de que o processo saúde-adoecimento é socialmente determinado, portanto, para efetivar a transformação da práxis social, os sujeitos necessitam compreender a realidade social na sua totalidade. Desse modo, para propiciar a reflexão crítica das enfermeiras sobre a práxis social, os conceitos abordados durante as oficinas emancipatórias tiveram por base os seguintes eixos temáticos: trabalho e processos de trabalho em saúde na Atenção Básica/trabalho do enfermeiro na $\mathrm{AB}$, concepções do processo 
saúde-doença/necessidades de saúde e políticas públicas de saúde/modelos de atenção em saúde.

Ainda, no período compreendido entre os meses de janeiro a março de 2014, foram realizadas cinco oficinas com o objetivo de elaborar um roteiro de VD, nos moldes de uma prática emancipatória, a partir da apreensão dos conceitos abordados nas oficinas anteriores foram discutidos na exemplaridade de casos vivenciados pelas enfermeiras participantes no trabalho cotidiano.

Em alguns momentos, para proporcionar maior aproximação da realidade das práticas, utilizou-se como recurso a dramatização de casos em grupo.

Os temas de cada oficina, bem como a estratégia utilizada para alcançar o objetivo proposto, são descritos no Quadro 2.

Quadro 2 - Temas, objetivos e estratégias utilizadas nas oficinas. São Paulo, 2013

\begin{tabular}{|c|c|c|c|}
\hline & Tema & Objetivo & Estratégia \\
\hline 1 & $\begin{array}{l}\text { - Apresentação dos } \\
\text { participantes e da } \\
\text { proposta das oficinas. } \\
\text { - Conceito de Trabalho e } \\
\text { Processo de Trabalho. } \\
\text { - Modelos de Atenção à } \\
\text { Saúde. }\end{array}$ & $\begin{array}{l}\text { - Constituir grupo; } \\
\text { - Apreender os elementos } \\
\text { constitutivos do processo de trabalho; } \\
\text { - Identificar a concepção de saúde } \\
\text { predominante nos Modelos. }\end{array}$ & $\begin{array}{l}\text { Roda de conversa; } \\
\text { Exercício da padaria* }\end{array}$ \\
\hline 2 & - Concepções de saúde & $\begin{array}{l}\text { - Identificar e contextualizar sócio- } \\
\text { historicamente as concepções do } \\
\text { processo saúde-doença. }\end{array}$ & $\begin{array}{l}\text { Leitura e discussão - texto "A História } \\
\text { do conceito de saúde", de Moacir } \\
\text { Scliar }\end{array}$ \\
\hline 3 & Necessidades de saúde & $\begin{array}{l}\text { Apreender necessidades de saúde } \\
\text { como necessidades de reprodução } \\
\text { social. }\end{array}$ & Exercício em grupo \\
\hline 4 & Retomada dos conceitos & $\begin{array}{l}\text { Situar as novas participantes sobre s } \\
\text { conceitos discutidos até o momento. }\end{array}$ & $\begin{array}{l}\text { Discussão em grupo - Exercício da } \\
\text { padaria }\end{array}$ \\
\hline 5 & $\begin{array}{l}\text { Necessidades de saúde e } \\
\text { processo de trabalho }\end{array}$ & $\begin{array}{l}\text { Identificar a circularidade } \\
\text { necessidades/trabalho }\end{array}$ & $\begin{array}{l}\text { Discussão em grupo; } \\
\text { Atividade: dimensões da prática do } \\
\text { enfermeiro }\end{array}$ \\
\hline 6 & $\begin{array}{l}\text { Práticas do processo de } \\
\text { trabalho do enfermeiro } \\
\text { na } \mathrm{AB}\end{array}$ & $\begin{array}{l}\text { - Identificar práticas específicas do } \\
\text { enfermeiro e na interface com a } \\
\text { equipe; } \\
\text { - Identificar abrangência das práticas } \\
\text { (dimensões: do indivíduo, da família } \\
\text { e da coletividade) }\end{array}$ & $\begin{array}{l}\text { Exercício individual - elencar as } \\
\text { práticas e suas dimensões. }\end{array}$ \\
\hline 7 & $\begin{array}{l}\text { Políticas públicas de } \\
\text { saúde }\end{array}$ & $\begin{array}{l}\text { - Reconhecer determinantes do } \\
\text { processo saúde-doença (necessidades } \\
\text { de saúde_ } \\
\text { - Elencar práticas em resposta a } \\
\text { necessidades de saúde. }\end{array}$ & $\begin{array}{l}\text { Discussão do texto "Brasil deve } \\
\text { aprender com epidemia de dengue no } \\
\text { Rio", Sabroza. }\end{array}$ \\
\hline
\end{tabular}


(continuação)

\begin{tabular}{|c|c|c|c|}
\hline & Tema & Objetivo & Estratégia \\
\hline 8 & $\begin{array}{l}\text { VD - Uma adolescente } \\
\text { gestante }\end{array}$ & $\begin{array}{l}\text { Modelo de VD que tome como } \\
\text { objeto do processo de trabalho as } \\
\text { necessidades sociais de saúde da } \\
\text { população. }\end{array}$ & $\begin{array}{l}\text { - Refletir sobre as diferenças entre } \\
\text { Saúde Pública e Saúde Coletiva. } \\
\text { Como são os processos de trabalho a } \\
\text { partir de cada perspectiva; } \\
\text { - Divisão em dois grupos; } \\
\text { - Um grupo realizou a encenação de } \\
\text { uma visita domiciliar; } \\
\text { - Enquanto o grupo ouvinte observou; } \\
\text { - Ao final, houve a discussão e } \\
\text { reflexão sobre os pontos falhos e } \\
\text { como poderiam alcançar as } \\
\text { necessidades sociais de saúde da } \\
\text { população em uma visita domiciliar. } \\
\text { Leitura de apoio: Educação em saúde } \\
\text { no trabalho de enfermagem, Almeida, } \\
\text { Trapé e Soares, } 2013 \text {. }\end{array}$ \\
\hline 9 & VD por óbito infantil & $\begin{array}{l}\text { Prosseguir com a construção de um } \\
\text { modelo de VD que tome como } \\
\text { objeto do processo de trabalho as } \\
\text { necessidades sociais de saúde da } \\
\text { população. }\end{array}$ & $\begin{array}{l}\text { - Divisão em dois grupos; } \\
\text { - O grupo ouvinte da oficina anterior, } \\
\text { realizou a encenação de uma VD; } \\
\text { - Enquanto o outro grupo observava; } \\
\text { - Ao final, procedeu-se com a } \\
\text { discussão e reflexão da VD. }\end{array}$ \\
\hline 10 & $\begin{array}{l}\text { VD para avaliação de } \\
\text { risco social }\end{array}$ & $\begin{array}{l}\text { Discutir sobre um modelo de VD } \\
\text { para aprimorar as condições de } \\
\text { vida da população. }\end{array}$ & $\begin{array}{l}\text { Discussão de caos com potencial } \\
\text { abrangente das necessidades sociais } \\
\text { de saúde. }\end{array}$ \\
\hline 11 & Construção do roteiro & Organizar o modelo de VD. & $\begin{array}{l}\text { - Estruturação do roteiro para material } \\
\text { audiovisual, escolha do caso, } \\
\text { discussão de recursos humanos e } \\
\text { materiais necessários. }\end{array}$ \\
\hline 12 & Construção do roteiro & Discutir o roteiro do modelo de VD. & $\begin{array}{l}\text { - Apresentação do roteiro estruturando } \\
\text { conforme sugestões da última oficina; } \\
\text { - Ajustes necessários para aproximar } \\
\text { da realidade vivida pelos } \\
\text { profissionais. }\end{array}$ \\
\hline
\end{tabular}

(conclusão)

\subsubsection{Descrição das oficinas emancipatórias}

A seguir são descritas as atividades desenvolvidas a cada encontro, os temas abordados e as estratégias adotadas para o desenvolvimento das oficinas emancipatórias.

Oficina 1 - tema: trabalho, processo de trabalho e processo de trabalho em saúde.

O encontro foi iniciado com a apresentação do projeto ao grupo, seus objetivos, a finalidade do estudo e qual estratégia estava sendo proposta com as oficinas emancipatórias; na sequencia as enfermeiras participantes apresentaram-se ao grupo e expuseram suas expectativas em relação às 
oficinas emancipatórias; após, as participantes que assentiram em participar da pesquisa procederam com a assinatura do TCLE - Termo de Consentimento Livre e Esclarecido.

Para apresentação dos conceitos às participantes, utilizou-se como estratégia o Exercício da padaria*, que propõe a descrição dos elementos constitutivos do processo de trabalho. A sequencia das atividades desenvolvidas nesse primeiro encontro são descritas abaixo.

1) Exercício da padaria - esse exercício teve por objetivo apresentar os elementos constitutivos do processo de trabalho, primeiramente em uma padaria por ser, como os serviços de saúde, uma atividade do setor terciário da economia.

2) as participantes, em grupos, elencaram a finalidade, o objeto, os instrumentos e os produtos do processo de trabalho de uma padaria, bem como a organização do trabalho. Na sequencia, as informações foram apresentadas e discutidas com o grupo todo.

3) contextualização histórica dos modelos de atenção à saúde pública no Brasil (saúde pública, saúde coletiva, nova saúde pública).

4) retomada do exercício, nos mesmos moldes do anterior, agora identificando os elementos constitutivos do processo de trabalho na AB.

Oficina 2 - tema: concepções do processo saúde-doença.

1) leitura e discussão, em grupos, do texto "A História do Conceito de Saúde", de Moacir Scliar $\ddagger$, com recomendação de leitura complementar: Costa JF. A medicina das cidades. In: Costa JF. Ordem médica e norma familiar. 5ed. Rio de Janeiro: Graal; 2004.

* Documento pedagógico para apoiar o desenvolvimento do tema em 31/8/00, sob a responsabilidade da Profa. Maria Josefina Leuba Salum, adaptado de Salum MJL, Queiroz VM, Ciampone MHT, Batista VD, Cortina I, Zambelli R, Tanaka L. Necessidades de aperfeiçoamento dos enfermeiros da Secretaria do Estado da Saúde do Estado de São Paulo diante do Sistema Único de Saúde. Saúde em Debate. 1996;51:508.

† Paim JS, Almeida Filho N de. Saúde coletiva: uma "nova saúde pública" ou campo aberto a novos paradigmas?. Rev. Saúde Pública [internet]. 1998 [citado 2013 out 02]; 32(4):299-316. Disponível em: http://www.scielo.br/scielo.php?script=sci_arttext\&pid=S003489101998000400001\&lng=en. http://dx.doi.org/10.1590/S0034-89101998000400001.

+ Scliar M. História do conceito de saúde. Physis. 2007;17(1):29-41. 
2) apresentação no grupo maior, articulando as concepções do processo saúde doença com a finalidade, o objeto, os instrumentos dos processos de trabalho em saúde, nos diversos modelos de atenção à saúde, até chegar nos modelos da Saúde Pública no Brasil.

Oficina 3 - tema: necessidades de saúde.

1) As participantes dividiram-se em dois grupos para desenvolver a atividade proposta, discutir e responder a pergunta: o que é preciso para que todos os moradores da área de abrangência de uma UBS tenham saúde?

2) As respostas dos grupos foram organizadas em uma tabela, de tal forma que foi se delineando a concepção de necessidades de saúde como necessidades de reprodução social (necessidade de reprodução social, presença do Estado e participação social) apresentadas por Campos, 2008.

Oficina 4 - Revisão de conceitos e aprofundamento da discussão sobre circularidade necessidades de saúde/trabalho em saúde.

1) Retomada da discussão dos elementos constitutivos dos processos de trabalho em saúde na $\mathrm{AB}$.

2) Identificação e discussão dos processos de trabalho em UBS organizadas pela ESF e a circularidade com necessidades de saúde, da perspectiva da Saúde Coletiva.

Oficina 5 - o trabalho do enfermeiro na $\mathrm{AB}$.

1) Exercício em grupos, em que participantes descreveram, num grande quadro impresso, as práticas realizadas pelos enfermeiros na UBS, identificando quais atividades delas eram realizadas com instrumentos específicos do enfermeiro e quais eram realizadas específicas pelo enfermeiro na interface com a equipe da UBS. 
3) as participantes descreveram a dimensão que incidia cada prática: individuo (dimensão singular), família/grupo (dimensão particular), grupos sociais (dimensão do coletivo).

4) Apresentação e discussão com a totalidade das participantes.

Oficina 6 - continuação da discussão da oficina 5.

1) A participantes deveriam descrever individualmente as práticas que desempenham na rotina do serviço de saúde, apontando a dimensão que atinge (singular, particular ou coletiva).

2) apresentação e constatação de que as ações na UBS são majoritariamente dirigidas a indivíduos. Foram apresentados resultados desse mesmo exercício, realizado anteriormente por enfermeiros de uma UBS do município, evidenciando a mesma tendência, as práticas incidem no âmbito singular.

3) discussão e sugestão de práticas que pudessem incidir nas dimensões particular e do coletivo.

4) indicação de leitura para o próximo encontro: Sabroza P. Brasil deve aprender com epidemia de dengue no Rio. Informe Ensp. 2008 abr. 04. , respondendo a questão: que práticas você, enquanto enfermeira de uma equipe da UBS, propõe para trabalhar com a questão da dengue no território de abrangência dessa UBS?

Oficina 7 - o trabalho do enfermeiro na $\mathrm{AB}$, na dimensão do coletivo.

1) apresentação e discussão do exercício proposto, sob o enfoque dos campos da Saúde Pública e da Saúde Coletiva.

2) apresentação de propostas das participantes sobre práticas da equipe na dimensão do coletivo.

Oficina 8 - VD a uma adolescente gestante

1) Os grupos procederam a discussão para elaboração do roteiro pela dramatização de uma situação que envolvesse a VD no cotidiano do trabalho na UBS; 
2) Enquanto um grupo encenou o outro observou e elencou pontos para serem discutidos, observando os elementos do processo de trabalho e o recorte do objeto para atender necessidades de saúde.

A VD encenada representou o caráter com que hegemonicamente as práticas na $\mathrm{AB}$ vêm sendo desenvolvidas. Era voltada a indivíduo de um dos grupos classificado pelo MS como grupo prioritário.

O caso representou a primeira VD que uma das participantes relatou ter feito ao iniciar como trabalhadora da $\mathrm{AB}$. Consistiu em uma visita a uma adolescente gestante para verificar a ausência dessa nas consultas de prénatal, ao chegar no domicílio, localizado em uma área de risco do território adscrito da US, a enfermeira relatou a precariedade das condições em que viviam. Eram três adultos, a adolescente, a mãe e a avó acamada que dividiam um colchão de casal, e agora, mais um bebê.

$\mathrm{Na}$ observação desse caso foi identificado a necessidade de planejamento prévio, que deve constar: reconhecimento das características do território, dos grupos sociais que lá habitam (características do trabalho e das condições de vida), além das informações específicas da família que será visitada e do indivíduo em questão.

Oficina 9 - VD por óbito infantil

1) O grupo observador da oficina anterior propôs a dramatização de uma VD relatada por uma das participantes;

2) Nessa segunda encenação, enquanto o segundo grupo encenou o outro observou e elencou pontos para serem discutidos, observando os elementos do processo de trabalho e a dimensão em que incidia a prática.

O caso escolhido foi de uma VD realizada pela enfermeira para investigar um caso de óbito infantil. As participantes avaliaram a postura do profissional ao abordar a mãe sobre o óbito, essa era drogadita, residiam em uma casa em precárias condições em uma periferia do município.

Nesse caso, as participantes identificaram a necessidade de articulação tanto multiprofissional, bem como de outras instituições, uma vez que a 
complexidade das necessidades de saúde requer outros instrumentos que somente o serviço de saúde pode responder.

Oficina 10 - VD para avaliação de situação de risco social

Nesse encontro os casos não foram dramatizados, as participantes descreveram vários exemplos vivenciados de VD, envolvendo diversos temas, verbalizando a necessidade de espaços de discussão e reflexão a respeito do trabalho cotidiano.

Reforçaram a necessidade do reconhecimento do território e da articulação com outros setores para o desenvolvimento de uma visita que amplie o objeto do processo de trabalho, ressaltando a deficiência do Estado, representado muitas vezes apenas pelo serviço de saúde e pela escola do bairro, marcada pela precariedade de condições de trabalho.

Oficina 11 - elaboração de roteiro da VD

1) Para compor o caso base para elaboração do roteiro de VD emancipatória foi escolhido o exemplo da primeira dramatização, referente à VD para uma adolescente gestante;

2) As participantes discutiram os pontos críticos a que o profissional deve atentar-se ao realizar a visita, envolvendo questões desde o planejamento até o resultado decorrente da visita. As enfermeiras apontaram aspectos convergentes com um recorte das necessidades de saúde da família visitada, fazendo referencia ao grupo social pertencente, o que possibilitou transcender às orientações protocolares ou do aprendizado durante a formação acadêmica, concebendo as condições de reprodução social.

Oficina 12 - elaboração de roteiro da VD

Com base no roteiro estruturado anteriormente o texto foi sendo aprimorado pelas participantes, de acordo com a realidade da prática em articulação com as discussões teóricas dos encontros anteriores (Apêndice I). 
$\mathrm{O}$ roteiro elaborado em conjunto com as enfermeiras resultou em material audiovisual com finalidade pedagógica, o qual será abordado em outro estudo que contempla o projeto matriz.

\subsection{ANÁLISE DOS DADOS}

As informações coletadas mediante a gravação das oficinas foram analisadas utilizando-se as categorias analíticas processo de trabalho em saúde e necessidades de saúde.

\subsection{PROCEDIMENTOS ÉTICOS}

Esta pesquisa integra o projeto "Necessidades de saúde como objeto das políticas públicas: as práticas de enfermagem na Atenção Básica”, de autoria da Professora Doutora Celia Maria Sivalli Campos (Campos, 2012). Esse projeto teve aprovação no Comitê de Ética em Pesquisa da Escola de Enfermagem da Universidade de São Paulo (Anexo II), sob número de processo 1104/2011; e pelo Comitê de Ética em Pesquisa da Secretaria Municipal de Saúde (Anexo III), sob parece número 037/12.

Os preceitos éticos e legais foram seguidos, conforme a nova Resolução do Conselho Nacional de Saúde - 466/12. As participantes foram informadas quanto aos objetivos da pesquisa, que as oficinas seriam áudiogravadas, com a divulgação das informações em veículos científicos com a garantia do anonimato, e aceitaram participar da pesquisa mediante assinatura do Termo de Consentimento Livre e Esclarecido (Anexo I), cientes de que poderiam retirar-se do estudo, ou eventual fala, a qualquer momento. 
5 Resultadas e análise 


\section{RESULTADOS E ANÁLISE}

A caracterização das participantes foi referente às oito enfermeiras que acompanharam todo o processo educativo, que culminou na elaboração do roteiro de VD emancipatória. Essas enfermeiras tinham idades variando de 26 a 51 anos. A média de tempo de formadas foi de 14 anos, atuando nesse período majoritariamente na $\mathrm{AB}$. Quanto ao local de atuação, seis desenvolviam a prática em serviços da $\mathrm{AB}$ e duas em STS, duas ainda trabalhavam como docentes. Apenas uma das enfermeiras não tinha curso de pós-graduação; seis tem curso de especialização, das quais quatro tem mestrado concluído e uma em andamento, duas tem doutorado e uma estava concluindo.

A apresentação dos resultados corresponde ao processo desenvolvido pelas participantes nas oficinas emancipatórias: da crítica ao conhecimento restrito da clínica ao reconhecimento dos conceitos da saúde coletiva, para a apreensão do objeto dos processos de trabalho na $\mathrm{AB}$.

Para elucidar esse processo, os resultados foram organizados nos seguintes temas: Da crítica sobre a falta de domínio à apreensão da finalidade como condutora do processo de trabalho em saúde; e, Da crítica ao objeto hegemônico da clínica à apreensão de necessidades de saúde como objeto do processo de trabalho em saúde.

\subsection{DA CRÍTICA SOBRE A FALTA DE DOMÍNIO À APREENSÃO DA FINALIDADE COMO CONDUTORA DO PROCESSO DE TRABALHO EM SAÚDE}

Inicialmente, após o exercício para reconhecimento dos elementos constitutivos do processo de trabalho, fazendo referencia ao processo desenvolvido em uma padaria, as participantes expressaram a compreensão da articulação entre os elementos do processo de trabalho (E1 e E6).

O excerto (E1) expressa como a participante identificou os elementos do processo de trabalho em uma padaria, já contendo a apreensão dos elementos envolvidos. Observa-se que a partir da ampliação do que chamou 
de 'objetivos' (finalidade), identificou a necessidade de ampliar o objeto de trabalho, consequentemente, dos instrumentos para chegar ao produto almejado.

Como a padaria, apesar de parecer simples, ela é muito complexa, a gente chegou uma hora que a gente tentou se limitar mesmo à questão do pão. A partir do momento que você pensa na higiene, na padaria, tem todo o instrumental. Se você pensa só na matéria prima do pão, então é uma coisa mais simples do que, conforme a gente foi evoluindo nos processos. (...) Se a gente pensasse qualquer item, se você pensa em oferecer cafezinho, já aumenta a mão de obra, já aumenta maquinário, já aumenta matéria prima. Então, por que a gente ficou no pão, justamente, porque senão cada vez que você oferece uma coisa, vai puxando de todos os lados. (...) Lembrando que cada produto gera toda uma cadeia de necessidades, né? Então se você acrescenta um item no seu objetivo... (E1)

Já nos seguintes depoimentos (E6, E5, E1), observa-se uma ideia mais organizada em relação aos elementos do processo de trabalho em saúde, ainda que mais abstratamente.

O objeto de trabalho é a saúde, e aí a minha finalidade é, através dos instrumentos que eu vou usar, pensar em um processo que transforme aquela condição, ou que promova saúde, ou que promova mais saúde, para aquilo onde eu quero chegar...(E6)

Assim, se a gente trouxesse para a saúde, né? Então aí o meu objeto, o que eu vou transformar, é a partir da necessidade do indivíduo, do usuário...(E5)

(...) lembrando que cada produto gera toda uma cadeia de necessidades, né?. Então se você acrescenta um item no seu objetivo...(E1)

As participantes identificaram que é preciso estabelecer a finalidade com a qual se desenvolverá o processo de trabalho. Os depoimentos E1 e E6 expressaram a reflexão das participantes a respeito do ponto inicial do processo de trabalho; ou seja, de que é a partir da finalidade que se dá todo o processo; é a finalidade que conduz o recorte do objeto e a escolha dos instrumentos que incidirão sobre ele.

Entendi que se a gente usasse uma outra maneira de pensar, a gente ia chegar mais longe, porque (...) quando se coloca o objetivo à frente, as outras coisas vão se compondo de uma maneira melhor (E1) 
(...) qual a finalidade (...) que eu quero oferecer? o produto final... Primeiro a gente definiu qual era o nosso objeto de trabalho e a matéria prima, o que a gente ia precisar para oferecer, (...) para a gente conhecer que produto que a gente ia estar disponibilizando... uma coisa está ligada na outra, né? (...) eu tenho que pensar nos meios que eu vou precisar para atingir o meu objetivo e depois, por último, qual é o planejamento que eu vou fazer (E6)

A reflexão também possibilitou que as participantes identificassem a articulação dos conceitos que explicam o processo saúde-doença, com os elementos constitutivos do processo de trabalho em saúde, como ilustra o depoimento (E6).

A concepção vai influenciar na sua finalidade, no produto final... na hora de traçar lá o seu plano, pensar como é que eu posso responder a esse problema... (E6)

Já o diálogo abaixo (E1 e E2) expressa a discussão das participantes sobre a articulação do processo de trabalho em saúde e o modo de produção mais geral da sociedade. Em uma primeira aproximação observa-se um discurso hegemônico e idealizado sobre o desenvolvimento das ciências no capitalismo, associando-o a melhoria das condições de vida da população. No entanto, as participantes identificaram que não é possível analisar os avanços ocorridos sem relacioná-los com a estrutura econômica, que marcadamente determina o modo como a finalidade do processo de trabalho foi se desenvolvendo.

Essa questão da saúde, das condições sanitárias e das condições que as pessoas viviam, eram ruins, independente do desenvolvimento industrial. A revolução industrial acho que trouxe mais benefício do que malefício, do meu ponto de vista. Então, eu sou bem capitalista, né? E você, comunista... Como tudo é uma fase, um ciclo, então foi por causa de tudo isso, essa revolução toda, que também houve avanço da ciência (...). [Antes disso], pro camponês que trabalhava para o rei, também era uma bosta (...) ele pagava impostos, a casa não era dele, a terra não era dele...(E1)

Existe uma apropriação do trabalho dele, que não é mais dele (...).É que a gente tem que avaliar a relação das pessoas com o trabalho e a gente não pode dizer que a forma como ela aconteceu, de uma forma, como você disse mesmo, correndo e caminhando, ela não foi planejada, né? Então o interesse do lucro era maior... 
realmente a gente tem que dizer que houve uma agudização muito grande da exploração do trabalhador. É claro que a gente não vai negar a tecnologia que ela trouxe... (E2)

Em continuidade, os depoimentos do diálogo abaixo (E2, E4 e E1) assinalam o movimento das participantes, que a partir de uma visão idealizada da construção histórica, passaram a uma análise da relação entre as dimensões políticas e econômicas que determinam as práticas em saúde, e de como os saberes da clínica médica ajustaram-se para responder às necessidades sociais do modo de produção capitalista, isolando a causalidade do processo saúde-doença do contexto social.

(...) você tira do desgaste do trabalhador, pela exploração capitalista, e joga no bacilo de Koch... (...). Não é porque vocês estão trabalhando 16 ou 20 horas, não tem onde dormir e ficam dividindo a cama com outras pessoas lá nos alojamentos da indústria, e não estão se alimentando. Não é isso, é o bacilo. (...) É claro que a gente não vai negar a tecnologia, que ela contribuiu, mas às custas da saúde de quem? ... das crianças menores de 9 anos... das mulheres gestantes, $n e ́ ?(E 2)$

Você está doente por causa de uma bactéria ou por causa do seu patrão? Como é que as famílias fazem com isso? (E4)

Se você tiver que culpar alguém, acho que se você culpar a bactéria é tranquilo, para o patrão... (E1)

Essa reflexão sobre a conformação das práticas em saúde possibilitou que as enfermeiras identificassem que a definição da finalidade é determinada a partir dos níveis centrais do sistema de saúde para responder a interesses próprios do processo de produção em saúde. Assinalam a compreensão de que essa finalidade concretiza-se nas diretrizes das políticas públicas de saúde, que respondendo a interesses do modo de produção mais geral, reduzem o objeto do processo de trabalho em saúde a doenças e agravos, prescindindo da identificação de outras necessidades de saúde.

No depoimento (E1) observa-se que inicialmente não há compreensão da subordinação da finalidade do processo de trabalho em saúde ao modelo de atenção (que é a operacionalização das diretrizes das políticas, que são instrumentos de mediação do Estado). Mediante as discussões identificou 
que as distintas finalidades são coerentes com os modelos de atenção à saúde, como expressa (E2), esboçando uma reflexão inicial e a percepção das características da finalidade da ESF.

O mais interessante, para mim, o que mais gostei disso daí foi que depois que a gente começou a enxergar esses modelos de saúde, que eu pelo menos nunca tinha parado para pensar... exatamente nessa questão do objetivo... além de clarear, a gente percebe que dentro de um modelo existe outro modelo. Como foi o higienista, a questão da vacina, que está ainda muito forte, esse modelo vem de uma assistência diferente (...) com o foco na doença, o modelo agora da saúde da família que, ficou aquela sensação de senso de saúde. Você entra na casa pra faz um levantamento das condições sociais, quase um senso, só que voltado para índices do Ministério da Saúde...(E1)

(...) Ao discutir os modelos [de atenção à saúde] a gente viu que o objeto (...) para um determinado modelo é a doença, (...) para outro modelo são os determinantes sociais. Então você pode ver vários fatores com o mesmo peso e [também] que as finalidades são diferentes. As finalidades daquele que [o objeto] é só doença, (...) é só tratar a doença, daquele que [o objeto] são os determinantes sociais é trabalhar com a rede intersetorial, e traz outros elementos, né? outros determinantes, trabalho principalmente (...) (E2)

A partir dessa compreensão mais geral do processo de produção em saúde, as participantes expressaram a crítica ao modelo de atenção à saúde, identificando que a finalidade proposta ao trabalhador não representa a realidade das necessidades de saúde da população, refletindo a disparidade no desenvolvimento das práticas quando o trabalhador tem uma visão de mundo, uma concepção do processo saúde-doença, que extrapola o recorte preconizado pelo modelo, conforme depoimento (E9) abaixo.

(...) dependendo do modelo assistencial, você pode ir até um certo ponto ou não, (...) porque nem sempre os modelos assistenciais tem como objeto as necessidades sociais, por isso que às vezes a gente se sente mesmo nadando contra a maré, porque a gente está com uma visão muito voltada para as necessidades de saúde da população (...). Só que o nosso jeito de trabalhar e se organizar não dá conta disso, e não vai dar conta, porque não está organizado para dar conta disso. A gente vai dar conta, sim, mal e porcamente, de fazer todas as VDs, de fazer todas as consultas, de mentir nos dados para dar conta de uma certa meta, porque o modelo não está olhando a melhoria das necessidades de saúde (E9) 
As falas a seguir (E4 e E1) expressam a valorização da ESF como um novo modelo, que propõe espaços de reunião e de discussões. No entanto, (E1) identifica entraves à concretização de ações que fogem ao âmbito da clínica, que na teoria a resolução dos problemas é alcançada pelo trabalhador, porém, na prática não é favorecida pela organização do serviço (E1). O excerto (E6) mostra que deve haver coerência entre os projetos da gestão e dos trabalhadores no serviço.

Acho que uma das coisas valorosas da equipe da Estratégia Saúde da Família é essa... proporcionar essas reuniões frequentes, que você tem um espaço de discussão, né, você só constrói alguma coisa coletivamente a partir da discussão (E4)

É que a gente tem uma noção, quando a gente está discutindo a gente sempre vai um pouco além, mas quando você vai por isso na prática, é tudo mais complicado, né? Essa mobilização, saber os caminhos, é bem mais complicado... Para você entrar em contato com o conselho gestor tem os horários... ish! (E1)

Falamos também da questão da gestão. (...) Porque se você também não tem um apoio a nível de cima, superior, você também... tudo bem... a gente anda... anda contra maré...(E6)

As participantes identificaram que o enfermeiro tem uma prática que é multifuncional, no que diz respeito à utilização de instrumentos desenvolvidos por outras áreas do conhecimento, mesmo sem ter o domínio delas (E4, E2) e, provavelmente, nem do objeto a ser transformado.

Sabe que de modo geral, a gente, o enfermeiro é o profissional que exerce, tem essa função tão primordial (...) pela própria formação. A nossa formação permite que a gente tenha esse olhar mais generalista, né? (...) A gente consegue discutir várias coisas. Por exemplo, não tem nutricionista, normalmente quem acaba fazendo é o enfermeiro. Não tem um psicólogo, muitas vezes a gente... né?, primeiro que é uma área de conhecimento que a gente perpassou na graduação, $e$ que tem um pouco de afinidade, são áreas que de alguma forma... a gente pode matriciar da enfermagem (E4).

A gente sabe... vocês perceberam isso nessa discussão até agora... então a gente sabe que a maior parte das nossas práticas, pela própria exigência de como o sistema se estrutura... não estou dizendo esse grupo, estou dizendo as práticas de saúde, né?, a forma como o próprio sistema se estrutura, a própria necessidade de produção, de cobrança de metas... de mostrar os 
números, a forma como a gente foi formado nas nossas escolas (...) (E2)

Os depoimentos abaixo expressam que o trabalhador não tem clareza da finalidade das práticas que realiza (E8), uma vez que, as necessidades de saúde da população, reconhecidas pelos trabalhadores, não são consideradas na elaboração das políticas (E2 e E4).
A finalidade dessa política pública não é a reversão,o aprimoramento dessas condições de saúde. Eu penso que ela responde a perguntas que são próprias dela, nem sei quais são as dela, a gente sabe muito pouco... (E8)
A meta foi criada de uma forma que não está respondendo às questões específicas daquele território. (...) Metas e indicadores são importantes, mas como foram escolhidas? quais são essas metas? (E2)
(...) tem toda essa demanda da prática Saúde da Família, (...) as cobranças vem em uma vertente muito do indivíduo, de quantas consultas... Você é muito cobrado nessa perspectiva de produção, do individual (...) e é visivel isso. (...) [Por exemplo], a necessidade de visita hoje não é dada através de uma necessidade da equipe, ela é dada através de metas que tem que cumprir, porque senão você pode ser mandado embora, que é o que as OS fazem (E4)

Os depoimentos acima expuseram a valorização de práticas pautadas nos saberes da clínica, desenvolvidas para responder demandas próprias do serviço (atingir metas, melhorar indicadores), não a partir de necessidades de saúde identificadas junto à população.

As participantes também sinalizaram a compreensão de que o trabalhador não domina o objeto nem os instrumentos, que são recortados para responder a finalidade instauradora do processo. Dessa forma, a prática fica engessada, como descreve o depoimento (E1), direcionada à utilização de instrumentos previamente definidos, como refletem os seguintes depoimentos (E6 e E1).

Algumas unidades da Estratégia da Saúde da Família tem tanta coisa, tanta coisa para preencher, para alimentar, (...) que as ações acabam se resumindo a alimentar os dados... (E6) 
Até fiquei meio assim... porque (...) na verdade também é muito engessado, (...) se for seguir esse protocolo, $e$ ainda esse protocolo estabelecer quantidade, hora, tudo... metas. (...) Aí o profissional tem que ser muito habilidoso para conseguir aproveitar e tirar uma coisa a mais... (E1)

$\mathrm{Na}$ mesma direção, os excertos abaixo exemplificam como essa lógica de produção mais geral se concretiza no cotidiano do trabalho (E1, E2 e E4). No excerto (E1) observa-se a percepção de que os modelos restringem a prática à dimensão técnica, o profissional fica condicionado à aplicação do instrumento, para responder as metas quantitativas (E2, E4). A repetição da utilização do instrumento torna-se um fim em si mesma, ocorre a sedução pelo instrumento (E4).

A gente chegou em um consenso de que a gente criava uma ação muito parecida, não importava o modelo, 'é hipertenso, corta o sal'. Isso para mim foi tudo! porque a gente começa a entender realmente (...). 'Está controlando o sal?, está tomando a medicação no horário certo?', e não interessa se você está em um modelo. Se você está em um ônibus e uma pessoa fala 'ah, eu sou hipertenso', é a mesma coisa. Se está na UBS, se está no PSF (...). Você vai tomar um cafezinho na padaria e o cara lá está com dor de cabeça, com pressão alta e você, é enfermeira, chega e fala: 'o senhor está tomando medicação?' (E1)

O modelo ainda é muito médico-centrado. A gente faz muita crítica ao modelo médico-centrado, mas na enfermagem, quando a gente está fazendo o protocolo, a gente está copiando o modelo médico. Então, por exemplo, me incomoda muito essa coisa da perspectiva, da valorização da consulta do enfermeiro em detrimento de um monte de outras atividades que tenham essa perspectiva coletiva. (...) Os protocolos, um monte de instrumentos para o enfermeiro trabalhar com carinha de médico, -se o paciente tiver não sei o que, você pode dar tal... olha que legal!, você pode prescrever!

E aí fica um negócio para retardado. Fica um negócio para enfermeiro retardado, (...) se o exame estiver assim, assim e assim... você vai fazer isso (...) e fica um negócio extremamente engessado porque você não quer entrar no papel do médico. O enfermeiro fica engessado, como se ele não pudesse pensar, o protocolo do enfermeiro não deixa as pessoas pensarem (...). Eu vejo um monte de enfermeiro encantado com essa coisa de fazer consulta e dos protocolos... e aí você perde toda a questão coletiva da construção da educação em saúde e tudo mais, 
brincando de ficar fazendo receita para tratar (E4)

A gente não pode dizer que o processo de trabalho [na ESF] não tenha grandes melhorias, mas o que acontece? A gente não tinha grupo de hipertensos $e$ diabéticos, só que a gente ainda fica falando da caminhada, do sal, (...) não aproveita a experiência das pessoas, (...) não usa reunião de hipertenso e diabético para discutir o córrego, para discutir a eleição do conselho local, para pedir a participação social. (...) $O$ nosso trabalho, o nosso tempo, as 8 horas, elas são organizadas para responder a metas. Sabe quando a gente faz as reuniões de saúde coletiva? (...) depois das 18 horas, (...) faz isso na hora do almoço, numa reunião com a escola. Então, devido a esse engessamento por essa cobrança de metas, (...) quem consegue mudar a lente? Ou então vai fazer um relatório dizendo 'o número de VDs não foi cumprido este mês porque foram realizadas tantas e tantas oficinas na escola', e torcer para que essa justificativa seja aceita, né? (E2)

O depoimento (E2) acima reitera a valorização dos saberes da clínica, expressa que o trabalho fica reduzido ao desenvolvimento dessas práticas, demonstrando que a realização de práticas que incidam no coletivo demanda esforço pessoal do trabalhador, realizando-as fora do horário de trabalho, a partir da visão que tem de mundo.

Nenhuma ação da gente... nunca é neutra. Todos nós temos um certo posicionamento político. Não partidário, mas político. É importante que a gente sempre parta dali, porque... por exemplo, com determinado óculos que a gente utiliza a gente vai ver que um determinado conjunto de ideias obscurece a questão social ou não. Com outro óculos você não vai enxergar isso. Você vai partir de uma outra explicação. (...) E é importante que esteja claro para a gente, porque é isso que vai influenciar nossa visão de mundo, a nossa visão de sociedade, nossa visão de saúde-doença e até o próprio instrumento que é a visita domiciliar lá na ponta do trabalho. Então, se você põe um óculos que olha que a necessidade é não ficar com aquela doença, é uma coisa. Se você põe o óculos que você vê que a necessidade é satisfazer algumas questões do trabalho, da vida, que interferem no processo saúde doença, é outra coisa. Então, depende... o protocolo seria a armação dos óculos, e a gente muda a lente (E2).

$\mathrm{Na}$ mesma perspectiva do depoimento anterior, o trecho abaixo (E6) expressa a apreensão das enfermeiras da articulação existente entre visão de mundo do trabalhador, a apropriação que cada um tem do conhecimento e 
da crítica que intencionaliza a transformação de práticas em saúde. No entanto, a fala denota a compreensão de que esse não é o movimento hegemônico, exigindo o a iniciativa do trabalhador.

(...) eu defendia uma coisa porque a minha visão de mundo era aquela realidade que eu vivia. E essa coisa que a gente discute aqui hoje (...) então, cada vez mais a gente vai se apropriando da história, pra poder pensar em novas formas de agir e mudar a nossa visão de mundo, porque a gente é facilmente corrompida. Até quem está no meio às vezes reproduz um discurso e (...) nem percebe que está reproduzindo (...); se você parar para pensar, estudar, discutir, "não é isso que eu penso!", mas a coisa sai porque é o que está no cotidiano, para manter o que? para manter o status quo. (...) A gente não foi educado para isso (...), para pensar coletivamente, para pensar os problemas sociais e o que isso implica (E6)

As enfermeiras expressaram a compreensão de que é possível a utilização do protocolo como instrumento auxiliar na transformação do objeto, não como um fim em si mesmo, caso o trabalhador disponha de conhecimentos para superar o domínio técnico do instrumento (E7).

Em relação ao protocolo, acho que quando você vê os protocolos e precisa seguir à risca isso, 'ah, essa parte não fiz, é outra que eu vou fazer', ai entra a questão do conhecimento do profissional. Então quando o profissional tem um acúmulo de conhecimento, tem essa bagagem, tem essa experiência, ele pode fazer bem mais, além do que aquele protocolo, e nem seguir à risca nem ficar amarrado, (...) ampliar (E7)

O trecho abaixo (E6) reitera a necessidade de práticas que incidam no âmbito da clínica, que são protocolares, para balizar o tratamento clínico. No entanto, mesmo essas práticas não podem prescindir da interface do sujeito que esta inserido em determinado grupo social (com suas características formas de trabalho e de vida). Sinaliza que ao desenvolver a prática sem essas considerações, a tendência é explicar os problemas de saúde a partir da culpabilização sujeito.

(...) nós precisamos das condutas, porque você precisa ter uma homogeneidade no tratamento (...). A consulta é individual, (...) por exemplo, pré-natal, eu tenho que pesar, eu tenho que verificar pressão, tenho que avaliar o crescimento uterino... Sabe, tem coisas que eu tenho que fazer. Mas junto com isso, na minha conversa, essa pessoa ela não é uma pessoa que só tem 
uma barriga que está crescendo, (...) que vai ser mãe $e$ tal. Ela tem todo ... de trabalho, de vida, de saúde, de família, de relação, de outras coisas que são tão importantes, além da questão técnica do pré-natal, que eu também tenho que fazer (...) e nós fazemos às vezes isolado de todo esse contexto. Porque... o que o senso comum diz e aí tem os meios de comunicação que ajudam, que você tem que ter uma qualidade de vida, que a alimentação saudável é assim, assim e assado. Porque fumar faz mal... (E6)

Os excertos abaixo (E3, E4, E2) mostram a fragmentação das práticas, expressando que há incoerência entre o objeto dos processos de trabalho em saúde, apesar desse ser o mesmo para todos (E3), dessa forma, não cabe a apenas um trabalhador aprimorar o objeto (E4). Já no depoimento (E2) observa-se uma síntese a respeito da coerência entre objeto e instrumentos, sinalizando que a complexidade das necessidades de saúde requer a ampliação do conjunto de instrumentos, inclusive os conhecimentos específicos de cada profissão da saúde, refletindo que a realidade cotidiana do trabalho é marcada pela fragmentação das práticas.

Às vezes a gente cuida do mesmo paciente mas cada um tem uma visão diferenciada...(E3)

Se a gente tem como finalidade aprimorar, não significa que eu tenho que dar conta de tudo... (E4)

(...) Uma coisa que eu sempre lembro, de uma figura (...) é a questão do diamante, do prisma; quer dizer: o objeto. Para todos os trabalhadores de saúde coletiva é o mesmo, são as necessidades sociais de saúde, né? Deveria, né? em saúde coletiva. (...) O enfermeiro vai olhar para uma face desse diamante, (...) o médico outra... mas é o mesmo objeto. A gente com os nossos instrumentos vai agir em determinados momentos, $e$ vamos precisar uns dos outros, com certeza. E não só da saúde... inclusive dos outros setores, né? [o objeto] é o mesmo, [a finalidade] é a mesma, (...) apoiar o processo de transformação dos perfis, né? (...) Na saúde coletiva você olha cada... todos os profissionais olham para o mesmo diamante, só que com os seus instrumentos... Eles trabalham com... Então, o que acontece é que a forma como vão se organizando nas especificidades, a fragmentação (...) eles param de olhar essa mesma pedra. Cada um fica achando que são coisas diferentes (E2)

No depoimento abaixo (E2), a enfermeira exemplifica essa

fragmentação do objeto em uma das práticas do cotidiano do trabalho. 
Um médico na UBS (...) foi fazer uma consulta, foi atender a dor de estômago da paciente; ele é residente na verdade. Então, ele tinha que gravar a consulta (...) e apresentar para o supervisor. (...) Ele atendeu (...) $e$ começou a conversar sobre a vida, sobre o trabalho, $e$ ela falando do ônibus, do transporte, que ela passava um nervoso desgraçado e [ele] começou a falar "você sabe que você pode ligar para tal lugar?"... Mas vocês acreditam que ele foi criticado? O supervisor dele falou: 'isso é uma ótima consulta de enfermagem, não é uma consulta médica'.(...) Então, essa questão do recorte do objeto, o próprio profissional recortar de uma forma tão reduzida que não consegue... não é que não vê a família, ele vê um pedaço do indivíduo (E2)

Nessa percepção da fragmentação do processo de trabalho, as discussões e reflexões possibilitaram que as enfermeiras identificassem como, concernente com a finalidade, os instrumentos também são escolhidos para responder aos interesses do processo de produção em saúde, conforme expõem os depoimentos (E9 e E4) abaixo.

O protocolo foi construído em certo momento histórico, dentro de certa política de governo que vai atender determinado interesse, que não necessariamente vai ser melhorar as necessidades de saúde. (...) Também reflete um pouco os interesses políticos, as forças políticas do momento... (E9)

(...) estão começando a modificar indicador, estão começando a fazer isso na saúde, eu fiquei extremamente preocupada; na educação pararam de reprovar e diminuiu o índice de analfabetismo. Agora sabiam que as crianças que nascerem com menos de 40 semanas são prematuras? É, agora é. A recomendação do Ministério é a amamentação exclusiva até os 6 meses, mas aí o indicador é 4 meses. Então assim, estão começando a burlar um monte de indicador porque não conseguem melhorar a meta. E aí tem uma pactuação... (...) assim, quando você está falando de avaliar o índice de mortalidade infantil, a prematuridade pode ser considerada como uma causa. Então, dá uma maquiada no coeficiente de mortalidade infantil, por isso que você tem mais prematuro. (...) e aí você fica falando "nossa, que coisa, né?" A gente está tentando melhorar a saúde e eles estão tentando maquiar indicador. (...) Será que realmente eles estão querendo mudar a saúde? porque a mamografia agora é 59 anos e a gente sabe que está aumentando o número de casos [de câncer de mama] com menos de 40 anos. Agora você não quer mais descobrir que elas tem câncer, é isso? Uma colega falou "nossa, fica mais difícil tratar”. Será que eles estão querendo tratar? Eles não estão nem querendo descobrir, imagina tratar, né? (E4) 
$\mathrm{Na}$ exemplaridade de dois instrumentos utilizados no processo de trabalho do enfermeiro na $\mathrm{AB}$, os grupos $\mathrm{e}$ a $\mathrm{VD}$, as enfermeiras identificaram distintas perspectivas que podem ser utilizadas ao realizar essas práticas, desde meramente protocolares até chegarem a identificar características de trabalho e vida dos grupos sociais.

Os excertos (E9 e E4) descrevem a VD e os grupos como instrumentos protocolares, utilizados para alcançar metas numéricas. Observa-se que as participantes expressam a crítica quanto à utilização dos instrumentos preponderantemente para ações clínicas, reiterando para a população a qual necessidade o serviço responde, necessidade de serviço de saúde.

(...) o instrumento tem sido usado para mera formalidade... - estou indo lá para ver, estou vendo a sua casa, estou vendo vocês -, anotei na minha planilha e estou indo embora, porque eu fiz o que o protocolo espera (E9)

Eu fui visitar Araçatuba, e lá, para o pessoal participar do grupo, eles distribuem cesta básica. Como a gente vai viciando a população que só o grupo não basta, né? Que só o grupo não é legal... (E4)

A gente ensina que o grupo é para vir trocar receita, também. Isso é prática comum já. Tem o grupo de trocar receita. Então esse dia mede a pressão, se der né... e troca a receita... (E9)

Nos depoimentos abaixo (E7 e E4) observa-se a reflexão sobre a utilização dos instrumentos (VD e grupo) já propondo a superação de práticas prescritivas, ainda que voltadas a utilização do instrumento numa perspectiva mais humanizada.

Eu diria que a visita domiciliária é um instrumento muito valioso na saúde coletiva, mas mais difícil de ser aplicado, né? Porque envolve essa sensibilidade, esse olhar diferenciado, essa escuta, de um profissional treinado, porque você chega lá e você não pode ser prescritivo... 'as panelas tem que estar bem areadas, não tem que ter rato, limpar a casa... tirar todos os bonecos de pelúcia, os bichinhos de pelúcia, que vai causar um broncoespasmo nessa criança', então é muito difícil. Não é fácil, eu já tive VD que a casa era tão precária, mas tão precária, que era um cômodo e moravam 10 pessoas. Que a pessoa (...) chegando lá ela falou: "dá para a gente conversar aqui fora?" "Dá, com certeza”. Então, ela com um bebezinho de 
colo e fizemos toda a nossa conversa, nosso diálogo fora porque não dava para entrar. Era o momento em que estavam todos descansando, eram 10 pessoas em um cômodo só (E7)

(...) E aí a gente percebe o ganho que tem um modelo de grupo educativo, que você pode propor, que também tem várias formas de se fazer um grupo educativo (...), e que não fica uma coisa vertical, que o médico está prescrevendo que você faça caminhada (...). A posição do profissional de saúde nesses grupos, é muito comum o moderador, né? alguém que vai direcionando para aquela coisa. Você pode provocar discussões, de alguma forma, elas não precisam vir aleatórias, a gente vai provocando pra chegar nesse ponto. (...) E acho que nunca ser impositivo, né? porque, ainda que o seu objetivo seja o mesmo, tem muitas formas de chegar nesse objetivo... (...) Acho que é isso, é olhar de forma crítica também... (E4)

A reflexão das práticas enquanto instrumentos do processo de trabalho possibilitou que as enfermeiras ampliassem o objeto sobre o qual incidem, destacando a necessidade de incorporar instrumentos para identificar as condições de reprodução social dos grupos sociais, como descrevem os trechos (E2 e E6) abaixo:

(...) interessante quando essa caminhada vira uma discussão - tá, mas vai andar aonde? (risadas). Tipo...não tem espaço para caminhar aqui, o espaço que tem a gente vai ser atropelado na [rodovia] Raposo [Tavares]. Então, isso já vai virando uma outra discussão que é a questão também de como você ocupar o espaço, o lazer, o direito ao lazer, a presença do Estado. Então é bem interessante, e a própria população sente, vive isso, mas o nosso papel é sistematizar isso, porque se você deixar fluir e forem discutindo, vai se chegar nessa conclusão e se organizar para isso (...). Não pode recair nem para o senso comum e nem legitimar o saber do técnico, o que a gente faz é uma construção conjunta, naquele momento a gente está construindo com eles, né? (E2)

A VD como instrumento, por exemplo, do olhar e do cuidado, né? Eu posso ir com uma finalidade ' $x$ ', mas se eu estou imbuída, se o meu instrumento de trabalho envolve entender como é que essa pessoa vive, onde ela mora, as dificuldades... porque também tudo isso é construído, um vínculo, na minha conversa eu amplio, vou olhar o bebê, vou levar uma receita, mas aproveito para junto com quem está ali comigo, na minha conversa, no meu diálogo, na minha observação, ir introduzindo em uma conversa novos elementos... no meu cuidado. (...) Trabalhar junto, construir um processo de trabalho, acho que aí entra coparticipação, co-responsabilização... vamos construir 
juntos. Vamos ver esse pedaço, vamos ver como a gente pode resolver esse problema que atinge aqui, mas atinge o vizinho, o outro, o outro. Os problemas sociais que também interferem naquela comunidade e assim vai indo... (E6)

Na exemplaridade de outra prática, em que as ações estão direcionadas para o coletivo, como é o caso da dengue, em um primeiro momento os instrumentos foram descritos voltados ao agravo, com ações prescritivas e focando apenas na eliminação do vetor, conforme observa-se no depoimento (E7). No entanto, com a continuidade das discussões, as enfermeiras identificaram a possibilidade de abranger os determinantes sociais, utilizando-se do mesmo instrumental, com a proposição de ações direcionadas aos grupos sociais, para aprimorar as condições de saúde, como expõe o depoimento (E2).

Mas a gente também teve uma experiência, pensando no território, com ACS. Antes de iniciar o verão, ou os casos de dengue, tem áreas da população da (...) que são áreas muito mais vulneráveis, (...) que tem um córrego que passa no meio das casas, dentro das casas. Quando a gente vai fazer visita domiciliar está a mãe, o bebê e o córrego do lado, passando por baixo... Então, a ACS que mora nessa área, que é considerada a área mais crítica, pensou em fazer um trabalho junto com a comunidade, com as creches, (...) para informar essas crianças. Então eles fizeram um trabalho com a comunidade, na perspectiva da prevenção, de olhar os vasinhos, os criadouros, em forma de teatro. Foram nas escolas, nas creches, na Unidade de Saúde, (...) foi bem bacana. Este ano eles acabaram sendo multiplicadores, as próprias escolas da região ficaram sabendo, no boca a boca, e convidaram eles para fazer esse teatro, tem até as roupas. Se a gente quiser chamá-los para fazer um teatro eles estão preparados. (...) A população gostou bastante (E7)

Estava pensando uma coisa, o processo educativo ele não depende tão somente do instrumento, que seria o teatro ou o panfleto. Por exemplo, você pode fazer um teatro que você faz uma interpretação e que está lá uma pessoa tirando aguinha do vaso e outra só dando orientação para ela, então foi só uma encenação. Ou você pode fazer um teatro, que você realmente comece a fazer uma crítica - 'mas por que você vai tirar a aguinha do vaso? que horas você chega em casa? será que você pega 2, 3 horas de condução?'. Ou 'por que estão juntando água nesses vasilhames?' Pode fazer um teatro nesse sentido. O panfleto também pode ser crítico, dependendo da coisa, como você escreve o panfleto, você começa a provocar. $O$ que a gente tem que ver mesmo é o objeto que a gente quer alcançar 
com a parte educativa, a gente está olhando mais para o inseto e a transmissão da doença e a água, ou a gente está olhando para toda essa estrutura da sociedade?... 'Por que a doença não se distribui igual pela cidade toda?' Então, isso também a gente tem que levar em considerações. A gente pode definir o instrumento, (...) dependendo do objeto que a gente quer trabalhar (E2)

No excerto (E2) acima observa-se a contraposição em relação ao trecho anterior, com ações para conter o inseto transmissor da dengue; aponta a necessidade de se discutir o todo, em suas relações sociais mais intimas com a utilização de um mesmo instrumento.

O depoimento abaixo (E2) aborda a possibilidade de desenvolver as práticas tradicionalmente voltadas à perspectiva individual, de modo que incidam no objeto da Saúde Coletiva, ou seja, nas necessidades de saúde. A enfermeira reforça a influencia da concepção do processo saúde-doença no recorte do objeto e por consequência, na utilização dos instrumentos.

(...) vai depender da forma como você enxerga o seu trabalho, né? (...) você pode coordenar os auxiliares na sala de vacina de forma que eles olhem só para o indivíduo, (...). Então um auxiliar na sala de vacina pode: 'pelo amor de Deus, por que você está atrasada de novo, com essa carteira de vacina desse jeito?' Ou 'mas por que você atrasou? -Ah! porque não consigo sair do meu trabalho, porque trabalho mais de 12 horas-. 'Mais de 12 horas? como assim mais de 12 horas?, você sabe o que é a CLT?'. Então é isso, porque vai depender do recorte, do olhar de quem está coordenando. (...) Se a gente está discutindo questões de sindicato com a pessoa que está ali, está fazendo atenção voltada ao grupo social, então vai depender de como o profissional consegue enxergar...(E2)

Nessa perspectiva, os trechos (E6 e E4) abaixo expressam a determinação dos instrumentos do processo de trabalho pelas políticas públicas, para responder a interesses próprios de manutenção do processo de produção em saúde, sem envolver a discussão das dificuldades do que é ter saúde, fazendo-se necessário espaços de reflexão junto à população (E2).

A partir do momento que o Estado é chamado para a responsabilidade de manter esse modelo de reprodução social do trabalho, aí eles tem que pensar em outros instrumentos, que consigam fazer com que tenha um equilíbrio... as políticas públicas elas não vem de graça. (...) A ideologia vigente, (...) o que querem passar? quais são os objetivos e a finalidade? 'Olha, como a saúde não está bem nós vamos convocar um 
maior número de médicos, porque os médicos vão resolver o problema da sua saúde'. Agora, não é discutido, não está sendo discutido as questões que envolvem... isso que nós estamos conversando aqui, as dificuldades, o que é ter saúde?. Ter saúde é ir lá no médico e o médico estar lá para me atender? (E6)

Acho que tem mais uma coisa, (...) as medidas não são efetivas porque elas não vêm de discussão, né? Hoje (...) o Estado chama o pessoal da Secretaria de Saúde do Município e fala assim 'gente, olha, tem um treinamento rápido da dengue, repassem para a maioria dos profissionais, escolham os multiplicadores, (...) tem que multiplicar assim, tem que montar um pronto socorro nesse esquema para atender as emergências, tem que capacitar a atenção básica para reconhecer as emergências e encaminhar para lá'. É isso que o Estado faz, porque eu já participei pelo menos de umas três ações assim. E aí, sem saber em que condições, dá o CDzinho, aí acha que te dá todas as condições porque te dá um CDzinho, sem nem saber se você tem computador na sua unidade. Fala: 'agora é só reproduzir...', só reproduzir? tem que envolver as pessoas (E4)

O trecho (E4) acima expõe a incongruência entre as orientações das diretrizes, e a realidade do serviço; assinalando a falta de dialogo, orientações passadas verticalmente, numa perspectiva de culpabilização do trabalhador.

Desse modo, os depoimentos (E8, E1 e E9) abaixo mostram que por mais que o trabalhador identifique a complexidade do processo saúde doença, que não se restringe apenas na manifestação do agravo no corpo biopsicossocial (E8). Sem a clareza da finalidade do processo de trabalho, não há o domínio do objeto (E1) e a prática acaba resumindo-se à respostas mediante demandas de serviços de saúde, não às necessidades de saúde (E9).

(...) a gente ainda pensou... acesso à saúde; ou seja, os equipamentos de saúde, ambientes politicamente saudáveis... que são prazerosos. Aí entra entretenimento, cultura, trabalho, habitação... (...). Estrutura, que significa saneamento, saneamento básico, rua, luz. Enfim, uma rua que você não caia, que você não quebre a perna, sem buracos. Educação, segurança, transporte, e que a participação social esteja em todo o processo (E8)

Mas o que caiu a ficha para mim, que eu fiquei mais..., mesmo! é como a gente não tem esse olhar político, né? A gente não consegue mudar lá em cima porque a 
gente (...) fica mesmo nesse modelo assistencial ali, mais médico, sempre porque a UBS trabalha muito com consulta; a prática da enfermagem ou é sanitarista, com as vacinas, com prevenção, ou é fazer a coleta para os exames que é para o médico saber o que o paciente tem. É focado na doença. Ou faz um curativo, que é para tentar o tratamento, que está em cima da doença (E1)

(...) acho que a gente se depara no cotidiano muito mais com demandas, e as demandas que ele [o usuário] vai trazer, de repente é uma consulta médica. Mas aí a gente quando faz, tendo em vista que o nosso referencial é de saúde coletiva acho que cabe a gente ajudar a transformar essa demanda em uma necessidade, traduzir... dar resposta para a demanda ou para a necessidade. Porque a demanda é muito mais fácil do que a necessidade (E9)

A incorporação de outros instrumentos ao processo de trabalho é mediada pela ampliação do recorte do objeto, uma vez que a complexidade do objeto demanda instrumentos mais ampliados, como expressa o depoimento (E1), exigindo inclusive a participação de práticas de outros setores e instancias (E10).

O paciente (...) às vezes a necessidade de apoio é tão grande, a pessoa está tão fragmentada, fragilizada, com um quadro familiar, social (...). Então, a gente tem estudado o indivíduo mais nas suas especificidades, e aí a gente vai trabalhar um pouco mais com a política, a gente precisa dos recursos que já conquistaram em outras instâncias, LOAS, recursos financeiros, os sociais... (...) parques (...). A gente tem que inserir essa pessoa na sociedade, garantir o recurso financeiro, então a gente sai um pouquinho mais... (E1)

(...) nós pensamos na complexidade desse indivíduo e dessa família e a gente pensou na participação popular, nos equipamentos de saúde e social e até o núcleo de apoio ao PSF [NASF]. Então, na ampliação da equipe para atender a todas essas necessidades que a gente elencou $($ E10)

Nessa perspectiva, ao observar que a complexidade do objeto requer outros instrumentos além dos saberes da clínica, no depoimento (E1) a participante propõe que o trabalhador tome todos os usuários na perspectiva da Saúde Mental. 
Se você pensar no hipertenso, se a gente colocar cada paciente como louco, porque a gente não sabe na verdade se aquela questão de hipertenso ali... A gente não sabe o que tem na vida dessa senhora. Você só falar que precisa cortar o sal da sua dieta...

As participantes identificaram, na exemplaridade de uma das práticas do processo de trabalho, a VD, que a depender do grupo social a demanda da VD é diferente (Fernanda E4), expressando como o Estado incide de maneiras distintas nas classes sociais (Ana Paula E1).

Tem outra coisa, onde a gente está indo, né?, porque aí
tem essa coisa das duas demandas, de fora para
dentro, de dentro para fora. E assim, por exemplo, se
você vai em uma comunidade carente a sua aceitação é
uma, na maioria das vezes, porque o pessoal já está
acostumado; se eu estou indo para fazer uma visita em
um lugar que é Estratégia Saúde da Família, a minha
aceitação é outra, o agente comunitário já é conhecido,
provavelmente vou conseguir entrar naquela casa, vai
ser bacana a conversa. Agora, dentro de uma área que
não é atendida, e você bate na casa das pessoas, que
muitas vezes não acessaram o serviço de saúde, tem
aquela perspectiva de que o SUS é para pobre e aí eu
vou dizer - olha, dá licença, eu sou da UBS. 'De
onde?' Do postinho. 'E veio fazer o que aqui?'. (...)
Pois é, e essas mesmas pessoas atendem a visita
domiciliar do home care com café... (E4)
(...) me ocorreu que o Estado tem uma influência
menor nas classes mais abastadas (...) (El)

As falas acima, expõem a reiteração da percepção de que o SUS é para pobre, com práticas fragmentadas e focalizadas. Demonstra a exemplaridade de uma prática, a VD, por mais que não tenha o caráter escancaradamente invasivo e policiatesco, abordando a naturalidade de adentrar nos domicílios mais pobres, uma vez que esses já estão habituados a receber a VD.

\subsection{DA CRÍTICA AO OBJETO HEGEMÔNICO DA CLÍNICA À APREENSÃO DE NECESSIDADES DE SAÚDE COMO OBJETO DO PROCESSO DE TRABALHO EM SAÚDE}

Nos depoimentos abaixo (E1, E4, E9) observa-se que inicialmente o objeto referido pelas participantes foram os predominantes nos serviços, direcionados ao indivíduo, na perspectiva de que as práticas alcançassem 
mudança de comportamentos e hábitos. Enquanto que no excerto (E9), observa-se o discurso para desculpabilizar o sujeito e ampliar o objeto.

Mas então, deixa ver se eu entendi. Nessa questão higienista e tal, quando a gente fala de estilo de vida, que todo mundo vê, todo dia na televisão, alimentação saudável, caminhada, esses conselhos que a gente, que enfermeira faz! Então, mesmo tendo consciência, mesmo estando em uma classe social alta, não faz porque depende... É interessante isso... (...) Você concorda que não é uma questão de dinheiro?, que, por exemplo, se você pega uma pessoa com uma condição financeira mais cômoda, mas ela tem melhor condição de ter uma vida saudável do que aquela... tem todo um conjunto de.... (...) não só o consumo, porque se for pensar em alimentação saudável, que são as verduras, frutas... até plantado no fundo do quintal, não é mais caro, né... E a questão da caminhada...(E1)

(...) o objeto seria promover saúde através de uma mudança comportamental. o comportamento a gente consegue transformar, que é o que mais a gente consegue transformar. Tem um como transformar o comportamento. Em algumas atitudes que elas conseguem promover essa mudança de comportamento, né...(E4)

Mas tem comportamentos que não dependem da pessoa necessariamente, é que aí a gente individualiza a questão. Se a gente tomar o comportamento como objeto...aí por exemplo não vai mudar a questão da habitação, porque a habitação não depende do comportamento necessariamente. Talvez a higiene do local sim, mas o local onde a casa está não. Então pensando no processo saúde - doença ampliado, nesse sentido a gente não incide sobre a doença ou a saúde... (E9)

Eu imaginei uma coisa voltada mais para a educação em saúde... entendeu? Algumas coisas que a gente consegue promover, ainda que em um ambiente inadequado, que a gente consegue melhorar algumas coisas. Por exemplo, algumas orientações que você faz, mesmo sobre a água, - olha, tudo bem, a sua água não é... mas se você ferver a água... né? -, algumas coisas assim de comportamento que você consegue... talvez modificar... (E4).

No diálogo abaixo (E1, E5, E6), observa-se a reflexão das participantes sobre a fragmentação do objeto do processo de trabalho na Unidades de Saúde, prevalecendo a prática direcionada ao âmbito da técnica (E5). 
(E1) O problema é quando você pega uma pessoa que vai numa UBS, e você a enxerga como se fosse uma pessoa que ela... (E1)

... é 'o hipertenso', 'o diabético'... (E5)

... é só isso, é só a ferida...(E6)

É a ferida, isso me incomoda demais na parte do tratamento de feridas, porque, o que acontece?, o indivíduo chega lá e ela olha a ferida, ela não olha a pessoa que tem uma ferida, e por que ela tem, e o que eu vou fazer, qual é o conjunto, o que a levou a ter essa ferida... nada. Eu faço um curativo, não faço tratamento de ferida. É diferente, eu faço procedimento técnico, sem olhar...(E5)

Refletindo os distintos recortes a partir da concepção do processo saúde doença, (E12, E1) apresentaram o objeto do trabalho em saúde fundamentando-o inicialmente na concepção multicausal do processo saúdedoença, e com a continuidade da reflexão, sinalizando-o com a compreensão da concepção da determinação social do processo saúde-doença (E1).

A finalidade seria melhorar as condições de vida, viver melhor, (...) todas as condições que envolvem a saúde dos indivíduos, as condições de saúde, com todas as variáveis que podem interferir na saúde daquele indivíduo; (...) não é atender só a questão 'quebrada' naquele momento. (...) A condição que se tem é resultado do que se pode ter de oportunidades na vida. (...) Por exemplo, se é um alto executivo vai ter determinadas oportunidades que talvez um técnico de enfermagem não tenha, de acesso e tudo mais: moradia, educação, até condição de trabalho (...). Então, a gente chegou nessa visão ampliada, de que o trabalho seria o tensionador, né? da qualidade de vida do indivíduo ou da família (E12)

Quando penso nessa questão de saúde (...), que a saúde ela é muito... assim, não é a infraestrutura que vai determinar, não é só as relações, é multifatorial. (...) A saúde é uma coisa tão complexa, né? Para ter saúde precisa ter uma casa, a gente acha que tem que ter um trabalho que faça sentido, que tenha condições adequadas, que tenha uma remuneração justa, uma alimentação saudável, ter acesso a saneamento básico, eletricidade, segurança pública, lazer na região, né? Espaço que proporcione esporte e lazer, transporte de qualidade, acesso à cultura, acesso à educação, liberdade de expressão, livre arbítrio e autonomia (E1) 


\section{E posteriormente}

Eles [os pacientes] param de tomar medicação para a avaliação [do INSS]. (...) muitas vezes a pessoa estava trabalhando e ela adoeceu, adoeceu e é afastada, às vezes o próprio trabalho está gerando esse adoecimento. Mas, qualquer pessoa que é afastada do serviço sabe que quando voltar vai ser mandada embora, porque normalmente esses serviços que adoecem são serviços que são... um salário mínimo $e$ tal e aí a pessoa sabe que vai ficar desempregada. Então, enquanto está recebendo o benefício ele está mais tranquilo e começa a fazer uns bicos. Não é que a pessoa está ganhando o INSS que ela cruza os braços $e$ senta no sofá, normalmente ela vai fazer uns bicos $e$ cria um jeito de viver. Tem uma renda que se não fosse o bico... mas, quando voltar para o trabalho, que normalmente é um salário mínimo (...). Quando ele volta, dá um tempo de um mês e ele é mandado embora (E1)

Em um primeiro momento, como apontam os excertos (E6, E7), o discurso sobre a dificuldade de ampliação do objeto de trabalho recaiu no trabalhador, o qual necessita de capacitação para atender ao usuário, numa perspectiva mais humanizada, não tão recortada apenas nos aspectos biológicos do sujeito, por meio do aprimoramento das práticas

\footnotetext{
Pensamos também na capacitação, na qualificação dos profissionais de atenção primária, na valorização, para que quando esse usuário chegue, tenha um atendimento diferenciado. [o trabalhador] Tenha uma ampliação da escuta, enfim, e que isso aí seja também colocado para que haja uma melhora da saúde... um conceito ampliado. E a gente também conversou sobre interdisciplinaridade... reforçar a questão da referencia e contra referencia, a comunicação entre os equipamentos. A gente considera muito vulnerável ainda, muito frágil...(E7)

... processo de construção e deconstrução... com critica, com reflexão e tudo mais... acho que essa é a diferença...(E6)
}

O depoimento (E6) expõe o questionamento a respeito da limitação de se restringir o objeto de trabalho à doença, ao controle dos sintomas, destacando a importância de conhecer as condições de reprodução social dos sujeitos; já o excerto seguinte (E1), expressa a necessidade do sujeito em uma perspectiva mais humanizada das práticas, assinalando a relevância dos aspectos sociais aos relacionais. 
(...) conhecer aquela pessoa, o contexto social em que ela vive, se ela trabalha, quais são as influencias que ela sofre no seu cotidiano, o que está interferindo no processo de saúde - doença dela, né? eu acho que isso é importante, conhecer para traçar um plano de cuidados (...) Vamos trabalhar juntas e vamos ver que condições que eu tenho, porque eu não consigo tirá-la daquele contexto, não existe fórmula mágica (...). Agora, qual meu objetivo? É só controlar a pressão dela? [perguntando]: está fazendo a dieta com pouco sal? tá tomando remédio? tá não sei o que?... (E6)

Também assim, para ter a questão da saúde... você... uma casa pode ser melhor do que a outra na infraestrutura dela. Mas a maneira como as pessoas cohabitam essa casa... o que acontece dentro dessa casa... Tem quem mora em uma mansão, mas tem problemas de família ou mesmo dele... ela pode não estar tão saudável como a pessoa que está no apartamentinho de 30 metros quadrados... (...) A saúde ela é muito assim, não é a infraestrutura que vai determinar, não é só as relações, é multi fatorial. (...) Não importa se você mora em uma casa melhor o pior... se a comunidade tem mais violência ou não. A comunidade é violenta, mas depende da maneira como você se insere nessa comunidade se corre mais riscos ou menos. (...) Acho que vai depender também de cada situação. Então assim, o trabalho é muito importante, mas tem muitas pessoas que elas não trabalham mas elas tem os vínculos,né? essas donas de casa, elas trabalham de outra maneira, porque como a gente tá falando de trabalho. (E1)

No diálogo a seguir (E4 e E1), observa-se a expressão de ampliação do objeto (E4) ao desenvolver ações voltadas à família durante uma prática, a VD. No entanto, no seguinte depoimento (E1) identifica-se que essa maneira de abordagem ampliada pode não incidir no processo de reprodução social daquela família.

Esses dias eu fui visitar uma paciente, a neta dela tinha acabado de ganhar bebê. Aí eu chego na casa, o bebê com duas semanas e ela está esquentando a mamadeira. Na porta, a médica foi lá para ver a paciente, eu fiquei ali: 'por que você está fazendo mamadeira e tal...'(E4)

É que a gente tem certeza de que a amamentação é o melhor para o bebê, mas a amamentação também cobra muito da mãe. Não é o bico rachado, não é isso, ela aprisiona, ela dificulta a saída da mãe para o mercado de trabalho (E1) 
$\mathrm{Na}$ discussão de ações direcionadas ao âmbito do coletivo, na exemplaridade da dengue, a concepção dos determinantes sociais do processo foram incorporadas, na medida em que as participantes identificaram questões estruturais (especulação imobiliária (E1) e falta de serviços de infra estrutura (E4)), na base do agravamento da incidência de dengue. No entanto, a proposição de estratégias permaneceu para o controle do agravo, do vetor.

Uma coisa que me chamou a atenção, que não é só a questão do vasinho, do pneu, né? Existem aquelas coisas de grandes áreas, alagados, terreno baldio com uma grande poça, que ninguém está vendo. (...) Me veio muito mais que os problemas não são individuais, não é só essa coisa do vaso (...), tem que olhar para o território; (...) se uma casa tem especulação imobiliária, quer dizer, você compra uma casa, a casa está para vender, (...) paga IPTU uma vez por ano e espera vender pelo preço que você está pedindo. Quem é que tem autorização de entrar nessa casa para ver se a piscina... entende? Então, acho que isso o governo deveria priorizar se ele quer combater a dengue (E1)

A perspectiva de que você tem que guardar água, porque você não tem acesso à água é uma coisa que simplesmente nunca tinha ouvido nenhuma discussão a respeito disso, falando de dengue. Foi uma coisa que me chamou muito a atenção, de você (...) precisar armazenar água porque não tem água na torneira, e é uma coisa muito frequente nessa época. Aquele jornal do SPTV (...) é uma notícia comum essa coisa da falta de água, do pessoal ir lá abrir a torneira e está sem água, não sei quantos dias, e o pessoal com aquele bando de baldes, né? Eu nunca tinha me tocado que isso é um problemão quando a gente está falando de dengue, e que é justo nessa época do ano, no litoral, o problema que eles tem de falta de água nessa época... (E4)

$\mathrm{Na}$ continuidade da reflexão, ao abordar sobre qual objeto as práticas de saúde incidem, os excertos abaixo (E4 e E2) expõem a reflexão sobre as raízes do problema, as necessidades de saúde. No depoimento (E4) observase a reflexão sobre a perspectiva estrutural do problema, de que não adianta desenvolver ações que não incidam nos determinantes do processo saúdedoença.

Eu não consigo imaginar uma política eficaz de ficar dando cloro para as pessoas que tem piscina, pensando em documento emancipatório. Fiquei pensando muito na questão da água, por um lado que não tinha visto. 
Nessa época tem os problemas da água, (...) porque falta água a ponto das pessoas terem que acumular (E4)

Acho que é interessante o exemplo da dengue (...). Eu lembro muito bem, estava no último ano da faculdade, o Nakano, foi lá na escola. Ele é urbanista e discute muito essa questão de que o território não é só o território geográfico, que não é só o lugar com prédios e casas, e árvores, mas que existe todo um espaço de reprodução social, de dinâmica social. Nunca vou esquecer, ele colocou um mapa e mostrou como a rede de água se distribui no município de São Paulo e como a rede de água é completamente relacionada com o conceito de exclusão social. Quer dizer, nas áreas periféricas realmente não tinha, não tinha. E nas centrais tinha.

Então, essa distribuição da dengue, é uma coincidência? A média acaba escondendo, mas quando você olha para o território, para o espaço geosocial e você vê a distribuição, com esse óculos, de olhar as diferenças de classes inseridas no território (...), aí sim, quando a gente faz uma intervenção a gente precisa mapear esses espaços. Quando você vai pensar na dengue é interessante que você mapeie quais são as questões de inclusão, exclusão do território, onde estão esses grupos sociais, para então a gente entender como que essa doença se distribui, para então pensar em intervenções baseadas, não exatamente na doença, mas baseadas nas causas das desigualdades da distribuição da doença. (...) Ela vai pegar todo mundo, só que as intervenções são diferentes. Por que? porque as causas são diferentes, né? Então, é como a hipertensão e diabetes. Pega todas as classes sociais, agora o que vai provocar em uma determinada classe a não (...) tomar o remédio, esquecer de tomar o remédio, não fazer a caminhada, é diferente do que vai determinar a outra classe (E2)

$\mathrm{O}$ excerto acima (E2), expressa a reflexão sobre as desigualdades sociais, de como essa perspectiva é mascarada na média dos indicadores de saúde, fazendo-se necessário a identificação da heterogeneidade dos grupos sociais, para desenvolver ações de acordo com as características dos grupos sociais. Essa compreensão é reiterada no depoimento (E6) abaixo.

Pensando nas necessidades sociais, nas necessidades de saúde, de uma área para outra tem (...) uma certa heterogeneidade. Então, se é na minha área de abrangência, ouvir, conhecer melhor essa população, que tipos de trabalho ela desenvolve, quais são as dificuldades que podem afetar, o que essa população acha... fazendo essa pergunta, né? 'o que é preciso para ter saúde?', acho que esse processo de construção ele é coletivo. (...) Se ele mora na rua é uma coisa, se ele tem trabalho remunerado é outra coisa, que garante os direitos e o acesso a essas coisas. Se ele tem 


\begin{abstract}
grana, se ele estuda, se ele tem vínculos, se ele não tem. Tudo isso, as necessidades de saúde são diferentes, tem a ver com o modo de inserção e o acesso que a pessoa tem aos bens (...). Nos grupos sociais é lógico, quanto menos favorecido, os problemas tendem a se acentuar, porque falta isso, falta aquilo, falta aquilo outro... Mas quando a gente trabalha com grupos sociais, a gente tem que lembrar, ainda mais aqui, que a nossa população é extremamente heterogênea.

Para a gente poder atender e conhecer essas necessidades [de saúde], fazer o planejamento e pensar em como vamos atuar, de uma forma trazendo essa população, é trabalhando com a questão de uma forma mais participativa. Porque as necessidades são ' $n$ ', $e$ elas variam conforme a inserção social daquele grupo que a gente está atendendo e trabalhando (E6)
\end{abstract}

Na compreensão de que é preciso olhar para as raízes dos problemas sociais para identificar as necessidades de saúde e, a partir disso, desenvolver o processo de trabalho com criticidade, com ações que reflitam nas necessidades de reprodução social dos grupos, a fala (E4) expressa essa compreensão, na exemplaridade do combate à dengue.

\footnotetext{
Melhor do que dar isso [caixa d'água] é a gente chamar para discussão as pessoas competentes $e$ apontar 'cadê o mapa aqui da distribuição de saneamento básico na cidade?'. Ok, vamos jogar o mapa da dengue aqui para ver o que tem a ver um com o outro, como a gente lida com isso. E aí acho que as práticas elas são mais eficazes, né? (E4)
}

A partir da reflexão e discussão sobre as práticas do cotidiano do processo de trabalho do enfermeiro, ancorados em conceitos da Saúde Coletiva, as participantes identificaram os elementos do processo de trabalho em saúde, e como a finalidade do processo de produção em saúde determina a finalidade das práticas impressa nos programas.

Esse processo reflexivo possibilitou, a partir da criticidade sobre o processo de trabalho em saúde, a elaboração em conjunto de um roteiro para VD emancipatória. 
6 Discussãa 


\section{DISCUSSÃO}

Os resultados demonstraram que ao longo do processo de elaboração do roteiro de VD as enfermeiras identificaram a articulação entre os elementos constitutivos do processo de trabalho em saúde e a coerência entre a concepção do processo saúde-doença e a finalidade que rege todo esse processo de trabalho.

O percurso das oficinas possibilitou a expressão, pelas participantes, de ideias enraizadas pelos trabalhadores, como por exemplo, a de que o desenvolvimento de práticas emancipatórias (expressas por elas como as operacionalizadas a partir da crítica às práticas hegemônicas e às formas alienadas) exige habilidade do trabalhador, numa compreensão de que esse é um atributo pessoal do trabalhador e de que cabe a ele o esforço para fazer a superação.

Pode-se pensar que essa culpabilização e responsabilização por parte dos trabalhadores estão relacionadas a não consciência do projeto da política estatal de saúde que se desenvolveu na constituição do SUS.

O SUS, instrumento da política estatal de saúde, foi fruto da pressão da sociedade civil, que reivindicava a democratização do direito à saúde, mas foi inscrito na Constituição como o resultado de embates entre grupos organizados com interesses diversos (Calipo, Soares, 2013), no contexto de efetivação do ideário neoliberal no país.

Nesse contexto, as políticas de saúde que se constituíram após o SUS favoreceram o projeto da saúde para o mercado e as políticas compensatórias. Nessas políticas, as práticas de saúde que ganharam destaque foram aquelas pautadas na concepção da clínica e do projeto de saúde como mercadoria (Campos, 2013).

O processo de produção em saúde segue a mesma lógica dos processos de produção mais gerais da sociedade. Portanto, a finalidade estabelecida verticalmente ao trabalhador de saúde responde a interesses próprios do modo de produção, dado que "o Estado capitalista possui um papel fundamental no processo de reprodução do capital" (Viana, 2006, p.8). 
A partir da década de 80 , a saúde passou a ser concebida como "um projeto que remete aos usos sociais do corpo e da mente. (...) a representação sobre a saúde e a vida saudável deslocou-se do âmbito do direito social para o de uma escolha individual" (Stotz, 2004, p.284). Concernente ao ideário neoliberal, adquirir essa saúde passou a ser possível, tal qual outra mercadoria.

No entanto, tendo por premissa básica a desigualdade social, nem todos terão acesso a essa saúde, os projetos das políticas públicas de saúde ficaram focalizados aos grupos marginalizados, "incapazes de prover sua própria subsistência numa sociedade de mercado" (Stotz, 2004, p. 284).

Uma vez que a dimensão que teve mais sucesso no neoliberalismo foi a dimensão ideológica (Boron, 1999), o trabalhador de saúde, no geral, se identifica com uma visão idealizada do SUS, não identificando o projeto que teve preponderância.

Essa constatação, além de expressa por participantes das oficinas, pode ser evidenciada também na literatura, que reitera a ideia de que a mudança dos processos de trabalho em saúde está nas mãos do trabalhador (Backes et al., 2012; Benito et al., 2005; Benito, Becker, 2007; Borges, Nascimento, 2005; Cubas, 2011; Gomes, Oliveira, 2005; Roecker, Budó, Marcon, 2012). Ou seja, a dificuldade para superar as práticas hegemônicas é atribuída ao trabalhador.

As discussões remetem a barreiras na formação profissional, que requer mudanças no currículo (Benito et al., 2005, Benito, Becker, 2007), a deficiências relacionadas ao perfil do profissional, quando não se identifica com as premissas da ESF ou não conhece a filosofia da Estratégia (Roecker, Budó, Marcon, 2012), ou deficiências no domínio de instrumentos do trabalho (Backes et al., 2012, Benito et al., 2005, Benito, Becker, 2007; Roecker, Budó, Marcon, 2012; Roecker, Marcon, 2011).

E inegável que os currículos dos cursos da área da saúde priorizam a formação teórico-prática centrada na concepção funcionalista do processo saúde-doença, a que "toma como sujeito o indivíduo em "situação de risco" para o desenvolvimento de alguma patologia e propõe a responsabilização 
do indivíduo pela manutenção ou pelo aprimoramento das condições de saúde, e mesmo pelo enfrentamento da doença" (Reis, Soares, Campos, 2010), promovem formação fragmentada (Cubas, 2011) e que é imprescindível formar trabalhadores "comprometidos com a interpretação da saúde-doença como processo social e da saúde como direito social e, portanto, com a transformação das práticas reiterativas do modelo hegemônico" (Soares et al., 2009, p.1231).

No entanto, também não se pode negar que se nessa lógica do processo de produção em saúde os serviços de saúde requisitassem trabalhadores para implementar processos de trabalho pautados nessa abordagem, alinhada aos conceitos da Saúde Coletiva, as universidades provavelmente se adequariam à essa necessidade requerida, uma vez que também tem respondido às necessidades do mercado de trabalho.

Ainda associada à performance do trabalhador, a manutenção da lógica curativista e médico centrada foi atribuída à prática dos gestores, por valorizarem a avaliação dos processos de trabalho por meio das metas e indicadores quantitativos de práticas direcionadas a grupos prioritários (Cubas, 2011; Roecker, Budó, Marcon, 2012), ações essas que, segundo (Cubas, 2011; Roecker, Marcon, 2011; Roecker, Budó, Marcon, 2012), são incoerentes com o caráter inovador da ESF.

No entanto, as práticas em saúde são instrumentos do processo de produção em saúde; portanto, os gestores são contratados para viabilizar as diretrizes das políticas estatais. Logo, não se trata de incoerência entre um caráter inovador e as práticas que não o operacionalizam, trata-se de coerência das práticas às finalidades expressas pelas diretrizes da política estatal.

$\mathrm{Na}$ ESF os processos de trabalho, as práticas realizadas pelos profissionais de saúde, reiteram as características do processo de produção mais geral, em que o processo é dividido e fragmentado e os trabalhadores perdem a compreensão da totalidade (Ribeiro, Pires, Blank, 2004, p. 439).

Essa fragmentação dos processos de trabalho acentua a artificialidade com que são recortados os objetos (Gonçalves, 1992). Consequentemente, o 
mesmo ocorre com os instrumentos utilizados, que se tornam cada vez mais desarticulados de um processo consciente, em que os trabalhadores estão alienados da finalidade do processo de trabalho (Almeida, Rocha, 1989).

A fragmentação das práticas também facilita a prática profissional multifuncional. Na divisão social do trabalho coube ao enfermeiro a parte mais manual do trabalho, o que pode explicar uma característica do trabalhador, que Cubas (2011) nominou como um profissional que "faz tudo". Ao mesmo tempo, essa característica dificulta a apropriação da finalidade do processo de trabalho, tornando-o um reprodutor de procedimentos dirigidos a partes do objeto a ser transformado, sem dominar a totalidade do processo.

As enfermeiras participantes das oficinas consideraram que essa divisão compartimentalizada do trabalho resulta em maior produtividade de procedimentos, em direção ao cumprimento de metas estabelecidas em nível central, mas também descaracteriza o trabalho em sua essência, que acaba por ser desenvolvido de maneira mecanizada, sem que haja uma reflexão sobre o processo de transformação do objeto. Expressaram a compreensão de que o objeto da prática vem previamente recortado pela finalidade identificada com os objetivos dos programas priorizados pelo MS; portanto, a finalidade é elaborada externamente às necessidades de saúde identificadas pelos trabalhadores e o objeto recortado traz consigo instrumentos coerentes com esse recorte, destacando o engessamento das práticas nos protocolos, que muitas vezes reduzem a finalidade da prática à sua aplicação.

Também os instrumentos privilegiados nas práticas da ESF são coerentes com a finalidade definida, que determina o recorte do objeto.

A organização do trabalho segue pautada em consultas nas áreas estratégicas (grupos prioritários) centradas no indivíduo (Cubas, 2011; Nascimento, Nascimento, 2005), e quando incorporam a família ao objeto da prática, é para relacioná-la as condições do ambiente físico ou aliá-la ao cuidado do indivíduo (Cubas, 2011). 
Diversos estudos sobre o trabalho do enfermeiro na ESF destacaram o predomínio de instrumentos do campo da clínica médica (Ermel, Fracolli, 2006; Kawata et al., 2013; Matumoto et al., 2011a; Ribeiro, Pires, Blank, 2004). As práticas são dirigidas a um indivíduo abstrato, que prescindem da perspectiva sócio-histórica, no máximo pautam-se na concepção multicausal do processo saúde-doença (Ermel, Fracolli, 2006), e que reproduzem a lógica do modelo liberal privatista ou do modelo racionalizador reformista (Matumoto et al. 2011b; Moretti-Pires et al., 2011; Nascimento, Nascimento, 2005; Roecker, Budó, Marcon, 2012;) presentes nas diretrizes da política estatal de saúde.

Essas práticas são as mais valorizadas pelos gestores (Roecker, Budó e Marcon, 2012), que são contratados para viabilizar o projeto da política estatal. Essa valorização obstaculiza o desenvolvimento de outras práticas, como as educativas que integrem a população (Roecker, Budó, Marcon, 2012), os gestores e trabalhadores, que efetivam a transformação das práticas (Pinto, Menezes, Villa, 2010) para que os participantes desenvolvam senso crítico, compreensão sobre causas e consequências do evento patológico e a capacidade de intervir sobre os problemas (Roecker, Nunes, Marcon, 2013).

Portanto, ainda que a educação em saúde seja considerada como um instrumento da prática do enfermeiro que pode incidir na dimensão da transformação do conhecimento de indivíduos e grupos sociais (Almeida, Soares, 2010), é pouco utilizado para esse fim.

Para Roecker, Nunes e Marcon (2013) as práticas educativas são desvalorizadas na $\mathrm{AB}$, tanto por usuários quanto por trabalhadores, sejam os da assistência direta, os coordenadores ou gestores municipais. Almeida e Soares (2010), e Croscrato e Bueno (2013), afirmaram que as práticas educativas desenvolvidas pelos enfermeiros são mais identificadas com a intencionalidade de transmissão de informações e conhecimentos da área biomédica.

Também a VD, que foi preconizada pela ESF como instrumento inovador das práticas hegemônicas da $\mathrm{AB}$, por permitir a aproximação com 
a realidade dos moradores (Brasil, 1997; 2007; 2012), parece continuar seguindo a lógica dos outros instrumentos dos processos de trabalho da ESF.

Pode significar apenas uma prática que busca aspectos préestabelecidos pelo trabalhador, numa observação parcial que reduz a realidade a um conjunto de fatores (Amaro, 2000), ou torna representativo o que não é (Amaro, 2000; Ribeiro, 2010), majoritariamente utilizada como instrumento de punição e de imposição, para fiscalizar e criticar os modos de vida das famílias, valendo-se de julgamentos do tipo certo-errado, limposujo, bem-mal. Não é incomum o trabalhador, já no planejamento da VD, verbalizar que é preciso "pegar de surpresa o usuário" (Ribeiro, 2010, p. 218-219).

Demandas precisam ser reconhecidas socialmente como necessidades, para que sejam implementados processos de trabalho em resposta a elas. Aos serviços de saúde é atribuída essa possibilidade (Stotz, 2004). Portanto, para que a $\mathrm{AB}$ implemente processos de trabalho para aprimorar objetos complexos, como a violência, precisa reconhecê-la como necessidade de saúde, para então implementar práticas ampliadas - ações multiprofissionais e intersetoriais. No entanto, Aragão et al. (2013) identificaram dificuldade na ESF para operacionalizar práticas de cuidado a pessoas acometidas por esse problema, uma vez que a preponderância é de resposta a necessidades recortadas pelos programas do MS.

A idealização a respeito da política de saúde que organiza a $A B$, que se contrapõe à clareza sobre a intencionalidade da política estatal e ao reconhecimento da lógica da organização do trabalho imposta por suas diretrizes, causa desgastes ao trabalhador. Pode-se dizer que "os trabalhadores da gestão que induzem as práticas, da mesma forma que os dos serviços, procuram de maneira idealizada atribuir às brechas [nas políticas de saúde] a potência para atender as necessidades (...) mais amplamente" (Campos, 2013: 65). 
Na ESF o enfermeiro é reconhecido como o trabalhador que coordena o cuidado (Backes et al., 2012; Escorel et al., 2009; Kawata et al., 2011; Sant'anna et al., 2011).

Há descrição de desgastes no trabalho do enfermeiro, associados ao número excessivo de famílias por trabalhador, ao suporte organizacional insuficiente e às decorrentes pressões dos usuários por insatisfação com a resposta do serviço às suas demandas (Feliciano, Kovacs, Sarinho, 2009), bem como associados à fragmentação do processo de trabalho e ao recorte prévio do objeto do processo de trabalho pela finalidade dos programas ministeriais, o que torna a prática alienada e sem o domínio dos elementos do processo pelo trabalhador (Santos, Soares, Campos, 2007).

A expressão desses desgastes no corpo dos enfermeiros foi descrita como quadros de adoecimento físico - alergias, hipertensão, dores de estômago e exposição de acidentes no trabalho e no trajeto - e mental, como ansiedade, sentimentos de insatisfação, impotência e frustração (Feliciano, Kovacs, Sarinho, 2009; Santos, Soares, Campos, 2007).

Portanto, reiterando a compreensão das enfermeiras a respeito da coerência entre os elementos do processo de trabalho, os achados da literatura (Cubas, 2011; Matumoto et al., 2011a; Roecker, Marcon, 2011; Roecker, Budó, Marcon, 2012) reafirmam que a finalidade dos processos de trabalho priorizados pela ESF induz objetos preponderantemente do âmbito do corpo biopsíquico de indivíduos ou dos espaços de moradia, em seu aspecto ambiental, que coerentemente requerem práticas baseadas nos saberes da clínica médica.

Assim como em qualquer trabalho, a função do instrumento é possibilitar que o homem transforme o objeto de trabalho em produto (Marx, 1980). Dessa maneira, as práticas que os trabalhadores da $\mathrm{AB}$ desenvolvem deveriam compor o conjunto de instrumentos para a transformação, o aprimoramento, das necessidades de saúde e não o seu domínio pelo trabalhador configurar um fim em si mesmo.

As enfermeiras relataram que a cobrança de metas quantitativas contribui para que o objetivo da prática fique identificado com os 
instrumentos, como é o caso dos protocolos utilizados em consultas de enfermagem, e acaba por restringir a prática à utilização dos instrumentos, desconfigurando assim a necessidade de domínio do processo de trabalho.

A concepção do processo saúde-doença traz consigo a possibilidade de eleger o objeto do processo de trabalho em saúde (Gonçalves, 1992), que responde a necessidades de saúde. Ou seja, para toda necessidade há um processo de saúde correspondente. Logo, os processos de trabalho em saúde deveriam responder a necessidades de saúde identificadas com os determinantes e condicionantes do processo saúde-doença, para cumprir a finalidade de aprimoramento da espécie humana.

No entanto, como o processo de produção em saúde é alinhado ao modo de produção mais geral da sociedade, os processos de trabalho em saúde são coerentes com sua finalidade e as políticas de saúde refletem a intencionalidade do Estado, como fica evidente na afirmação:

\begin{abstract}
os sistemas de atenção à saúde são respostas sociais deliberadas às necessidades de saúde das populações que se expressam, fundamentalmente, nas suas situações de saúde. Por consequência, deve haver uma sintonia muito fina entre essas necessidades de saúde e a forma como o sistema de atenção à saúde se organiza para respondê-las socialmente (Mendes, 2012, p 38).
\end{abstract}

Por isso, as necessidades de saúde são tomadas como necessidades de procedimentos realizados pelos serviços de saúde e os processos de trabalho em saúde, que também reiteram as necessidades, induzem ao consumo de bens e serviços (consultas, exames, medicamentos, produtos disponíveis no mercado), respondendo a interesses do processo de produção.

Portanto, é possível afirmar que a responsabilização por fazer cumprir os princípios do SUS e operacionalizar os fundamentos da ESF que os trabalhadores atribuem a si, reforçada pelas publicações sobre o tema na literatura, tem suas raízes na aparente incoerência entre a finalidade do modelo de atenção em saúde, declarada como sendo a superação do modelo hegemônico, e a operacionalização das práticas no cotidiano do trabalho na $\mathrm{AB}$. 
Para fortalecer os trabalhadores Roecker, Budó e Marcon (2012) reforçam a necessidade de interação entre os trabalhadores da equipe multiprofissional para desconstruir a concepção dos usuários do serviço de saúde, que é reiterada pelo serviço de saúde. Rodrigues, Fracolli e Oliveira (2001, p.318), sugerem que "as discussões relativas às concepções de trabalho em saúde, trabalho de enfermagem e processo saúde-doença podem se constituir em instrumentos potentes para subsidiar as transformações do trabalho".

Os espaços pedagógicos de educação e de interação da equipe com a coletividade para reflexão das práticas foram definidos como instrumentos que favorecem o desenvolvimento de ações coletivas de atenção à saúde e proporcionam a integração entre os trabalhadores das equipes (Cubas, 2011; Matumoto et al., 2011a) e a desfragmentação das práticas (Lima et al., 2012).

Os autores (Cubas, 2011; Lima et al., 2012; Matumoto et al., 2011a) sinalizam a educação permanente ou continuada como processos educativos, direcionados ao aprimoramento das práticas do enfermeiro. Ou seja, para aprimorar os instrumentos de trabalho do enfermeiro.

A partir da divisão técnica do trabalho médico, ao enfermeiro coube a parte mais manual do trabalho, valorizando-se desde a formação aquela atrelada à utilização dos instrumentos, ou seja, da dimensão técnica em detrimento da dimensão teórica (Campos, 2013). No entanto, o reconhecimento da finalidade e o recorte do objeto do processo de trabalho só é possível a partir do domínio da dimensão teórica (Abrantes, Martins, 2007).

Desse modo, como afirmam Abrantes e Martins (2007, p.319)

A prática social pressupõe domínios teóricos e práticos e, assim sendo, quando o sujeito do conhecimento empreende um pensamento sobre a realidade, tendo em vista nela intervir, a qualidade da sua intervenção estará na dependência dos domínios conceituais que lhe estão disponibilizados, ou seja, o pensamento (como expressão da capacidade de conhecer) não é um bem espontâneo que se ativa automaticamente quando um indivíduo é exposto à realidade. Ele se desenvolve como conquista do ser social, em processos de ensino, cujo acervo resulta da história humana objetivada como 
riqueza pela ação práxica dos indivíduos que se apropriam dessas conquistas históricas (Abrantes, Martins, 2007, p.319).

Com essa compreensão, neste trabalho propôs-se como processo educativo aquele que permite a consciência das contradições que estão nas bases das relações sociais concretas e propõe o desenvolvimento de amplos e profundos processos de reflexão entre os trabalhadores (Almeida, Trapé, Soares, 2013). Para que além de instrumentalizar a resistência à lógica do mercado como ditador da formulação das políticas de saúde, que também possibilite processos de trabalho questionadores das práticas hegemônicas, incluam no cotidiano do trabalho práticas de cuidado emancipatórias.

Tomando a circularidade entre necessidade e trabalho, as práticas emancipatórias são instrumentos instauradores de necessidades de saúde no âmbito dos sujeitos dos grupos sociais, para além de responderem aos problemas de saúde já expressos no corpo biopsíquico dos indivíduos (Campos, Soares, 2013).

Portanto, para instaurar práticas emancipatórias, que incidam na dimensão dos grupos sociais, superando as práticas programáticas definidas verticalmente, parte-se do reconhecimento de necessidades de reprodução social dos grupos sob a responsabilidade da USF (reconhecimento das características do território, como espaço geo-social, das condições de trabalho e de vida dos indivíduos e famílias dos diferentes grupos sociais), elaborando ações intersetoriais - que são as que incidem nos determinantes das necessidades de saúde, "para efetivar o fortalecimento dos grupos sociais na luta para a emancipação humana, para o desenvolvimento pleno de todas as suas capacidades" (Campos, 2013: 76). 
7 Cansideraçães finais 


\section{CONSIDERAÇÕES FINAIS}

Este trabalho respondeu aos objetivos propostos.

Ao primeiro objetivo - identificar as práticas em saúde como instrumentos do processo de produção em saúde - o processo educativo desenvolvido por meio de oficinas emancipatórias possibilitou às participantes identificarem a subordinação das práticas em saúde ao processo de produção em saúde.

A compreensão da articulação do processo de trabalho no contexto mais amplo das relações de produção, implementado como instrumento para manutenção desse modo, possibilitou que as participantes saíssem do discurso idealizado das práticas, compreendendo-as com mais criticidade.

Ao segundo objetivo - apreender as dimensões teórico-metodológicas que embasam a compreensão de práticas emancipatórias em saúde - as enfermeiras expressaram a apreensão das bases conceituais da Saúde Coletiva - processo de trabalho em saúde e necessidades de saúde, objeto dos processos de trabalho em saúde.

As participantes identificaram a essencialidade da compreensão da finalidade que rege o processo de trabalho, sem a qual o trabalhador perde o domínio do processo de trabalho, bem como do recorte do objeto e dos instrumentos.

Nesse sentido, imbuídas da dimensão teórica que ancora o processo de trabalho, as participantes apreenderam a relação de subordinação do processo de trabalho em saúde aos interesses do processo de produção mais geral da sociedade no capitalismo, possibilitando a compreensão do processo de trabalho em sua totalidade.

Ao terceiro objetivo - elaborar um roteiro de VD como uma prática emancipatória em saúde - as participantes elaboraram um roteiro de VD que partiu da concepção da determinação social do processo saúde-doença para interpretar o fragmento da realidade - gravidez na adolescência, e propor ações para respondê-la, a partir da VD, tanto no âmbito singular, quanto no particular e no coletivo, superando a limitação das práticas hegemônicas, 
fundamentadas na concepção da clínica e do mercado, para transformar a realidade de saúde.

Desse modo, a VD foi apresentada como prática emancipatória na $\mathrm{AB}$, com potencialidade para aprimorar as condições de saúde da população, recortando necessidades de saúde como objeto do processo de trabalho em saúde.

O que permite superar práticas engendradas na concepção da clínica e do mercado, em direção a práticas emancipatórias, é primeiramente tomar consciência da intencionalidade do desenvolvimento das práticas induzidas pelas políticas estatais, enquanto forma de regularização do modo de produção em saúde, que reproduz o modo de produção social mais geral. 
Referências 


\section{REFERÊNCIAS}

Abrantes AA, Martins LM. Scientific knowledge production: the subjectobject relationship and thought development. Interface (Botucatu). 2007;11(22):313-25.

Albuquerque ABB, Bosi MLM. Visita domiciliar no âmbito da Estratégia Saúde da Família: percepções de usuários no Município de Fortaleza, Ceará, Brasil. Cad. Saúde Pública. 2009; 25(5):1103-1112.

Almeida MCP, Rocha JSY. O saber de enfermagem e sua dimensão prática. São Paulo: Cortez; 1989.

Almeida AH de, Soares CB. Ensino de educação nos cursos de graduação em enfermagem. Rev. Bras. Enferm.[internet]. 2010 [citado 2014 jun 13];63(1):111-116. Disponível em: http://dx.doi.org/10.1590/S0034-716720 $\underline{10000100018 .}$.

Almeida AH de, Trapé CA, Soares CB. Educação em saúde no trabalho de enfermagem. In: Soares CB, Campos CMS, organizadoras. Fundamentos de Saúde Coletiva e o Cuidado de Enfermagem. São Paulo: Manole; 2013. p.293-322.

Amaro STA. Visita Domiciliar: orientações para uma abordagem complexa In: Desaulniers JBR, organizadora. Fenômeno: uma teia complexa de relações. Porto Alegre: EDIPUCRS; 2000. p.195-202.

Aragão AS et al. Primary care nurses' approach to cases of violence against children. Rev. Latino-Am. Enfermagem. 2013;21(spe):172-179.

Azeredo CM, Cotta RMM, Schott M, Maia TM, Marques ES. Avaliação das condições de habitação e saneamento: a importância da visita domiciliar no contexto do Programa de Saúde da Família. Ciênc. saúde coletiva. 2007;12(3):743-753.

Backes DS, Backes MS, Erdmann AL, Büscher A. O papel profissional do enfermeiro no Sistema Único de Saúde: da saúde comunitária à estratégia de saúde da família. Ciênc. saúde coletiva [internet]. 2012 [citado 2014 jun 15];17(1):23-230. Disponível em: http://dx.doi.org/10.1590/S1413-812320 12000100024.

Benito GAV, Becker LC, Duarte J, Leite DS. Conhecimento gerencial requerido do enfermeiro no Programa Saúde da Família. Rev. Bras. Enferm.[internet]. 2005 [citado 2014 jun 15];58(6):635-640. Disponível em: http://dx.doi.org/10.1590/S0034-71672005000600002. 
Benito GAV, Becker LC. Atitudes gerenciais do enfermeiro no Programa Saúde da Família: visão da Equipe Saúde da Família. Rev. Bras. Enferm.2007;60(3):312-316.

Boron AA. Os "novos Leviatãs" e a pólis democrática: neoliberalismo, decomposição estatal e decadência da democracia na América Latina. In: Boron AA et al; Sader E, Gentili P e orgs. Pós-neoliberalismo II: que Estado para que a democracia? Petrópolis, RJ: Vozes, 1999.

Borges R, D’Oliveira AFPL. A visita médica domiciliar como espaço para interação e comunicação em Florianópolis, SC. Interface (Botucatu). 2011;15(37):461-72.

Borges MASF, Nascimento MAA. A concepção da enfermeira sobre o SUS: um caminho sem volta. Rev. Bras. Enferm.2005;58(3):272-277.

Brasil. Ministério da Saúde. Secretaria de Assistência à Saúde. Coordenação de Saúde da Comunidade. Saúde da Família: uma estratégia para a reorientação do modelo assistencial. Brasília: Ministério da Saúde; 1997.

Brasil. Ministério da Saúde. Secretaria Executiva. Programa agentes comunitários de saúde (PACS). Brasília: Ministério da Saúde; 2001a.

Brasil. Ministério da Saúde. Secretaria Executiva. Programa Saúde da Família. Brasília: Ministério da Saúde; 2001b.

Brasil. Ministério da Saúde. Secretaria de Atenção à Saúde. Departamento de Atenção Básica. Política Nacional de Atenção Básica. Brasília: Ministério da Saúde; 2007.

Brasil. Ministério da Saúde. Secretaria de Atenção à Saúde. Departamento de Atenção Básica. Política Nacional de Atenção Básica. Brasília: Ministério da Saúde; 2012.

Buhler-Wilkerson K. Public Health Nursing: In Sickness or in Health?. AJPH. 1985; 75(10):1155-1161.

Calipo SM, Soares CB. Saúde como direito. In: Soares CB, Campos CMS, organizadoras. Fundamentos de Saúde Coletiva e o Cuidado de Enfermagem. São Paulo: Manole; 2013. p. 3-48.

Campaña A. Em busca da definição de pautas atuais para o delineamento de estudos sobre condições de vida e saúde. In: Barata RB, organizadora. Condições de vida e situação de saúde. Rio de Janeiro: ABRASCO; 1997. p.115-65. 
Campos CMS. Reconhecimento das necessidades de saúde dos adolescentes. In: Borges ALV, Fujimori E, organizadoras. Enfermagem e a saúde do adolescente na atenção básica. Barueri: Manole Ed; 2009. p.142167.

Campos CMS. Necessidades de saúde como objeto das políticas públicas: as práticas de enfermagem na Atenção Básica [relatório parcial FAPESP]. São Paulo: Escola de Enfermagem, Universidade de São Paulo; 2012.

Campos CMS, Soares CB, Trapé CA, Silva BRB, Silva TC. Articulação teoria-prática e processo ensino-aprendizagem em uma disciplina de Enfermagem em Saúde Coletiva. Rev. Esc. Enferm. USP [internet]. 2009 [citado 2014 jun 15];43(spe2):1226-1231. Disponível em: http://dx.doi.org/ 10.1590/S0080-62342009000600014.

Campos CMS. Necessidades de saúde como objeto das políticas públicas: as práticas do enfermeiro na Atenção Básica [tese livre-docência]. São Paulo: Escola de Enfermagem, Universidade de São Paulo; 2013.

Campos CMS, Soares CB. Necessidades de saúde e o cuidado de enfermagem em saúde coletiva. In: Soares CB, Campos CMS, organizadoras. Fundamentos de Saúde Coletiva e o Cuidado de Enfermagem. São Paulo: Manole, 2013. p.265-292.

Chiesa AM, Westphal MF. A sistematização de oficinas educativas problematizadoras no contexto dos serviços públicos de saúde. Saúde debate. 1995;46:19-22.

Cordeiro L, Soares CB, Campos CMS. Pesquisa ação na perspectiva da Saúde Coletiva: relato de experiência da formação de agentes comunitários da saúde para o enfrentamento do consumo prejudicial de drogas. Sau. \& Transf. Soc. 2013;4(2):106-116.

Coscrato G, Bueno SMV. Concepção de enfermeiros de uma rede pública de saúde sobre Educação para a Saúde. Rev. Esc. Enferm. USP. 2013;47(3):714-721

Cowley S. Principles of British health visiting. Rev Esc Enferm USP. 2007; 41(N. esp.):756-61.

Cubas MR. Desafios para a enfermagem no alcance das metas da atenção primária. Rev. Esc. Enferm. USP. 2011;45(spe2):1758-1762.

Cruz MM, Bourget MMM. A visita domiciliária na Estratégia de Saúde da Família: conhecendo as percepções das famílias. Saude Soc. 2010;19(3):605-613. 
Dantas-Berger SM, Giffin KM. Healthcare services and violence during pregnancy: perspectives and practices of healthcare professionals and teams in a public hospital in Rio de Janeiro. Interface (Botucatu). 2011;15(37):391-405.

Egry EY, Fonseca RMGS. A família, a visita domiciliária e a enfermagem: revisitando o processo de trabalho da enfermagem em saúde coletiva. Rev. Esc. Enferm. USP. 2000;34(3): 233-9.

Engel IG. Pesquisa-ação. Educar. 2000;16:181-191.

Ermel RC, Fracolli LA. O trabalho das enfermeiras no Programa de Saúde da Família em Marília/SP. Rev. Esc. Enferm. USP. 2006;40(4):533-539.

Escorel S, Giovanella L, Mendonça MHM, Senna MCM. O Programa de Saúde da Família e a construção de um novo modelo para a atenção básica no Brasil. Rev Panam Salud Publica. 2007;21(2):164-176.

Espírito Santo TB. Enfermeiras francesas na capital do Brasil (1890-1895) [dissertação]. São Paulo: Escola de Enfermagem da Universidade de São Paulo; 2007.

Eufrásio RG, Alcântara Junior JE, Araújo LR, Negreiros MAMP. Detecção precoce de carcinoma basocelular: importância da visita domiciliar no contexto da atenção integral à saúde do idoso. Rev. APS. 2010;13(2):241-244.

Feliciano KV de O, Kovacs MH, Sarinho SW. Superposição de atribuições e autonomia técnica entre enfermeiras da Estratégia Saúde da Família. Rev. Saúde Pública. 2010;44(3):520-527.

Fertonani HP, Pires D. Concepção de saúde de usuários da Estratégia Saúde da Família e novo modelo assistencial. Enfermagem em Foco. 2010;1(2):51-54.

Franco MAS. Pedagogia da Pesquisa-Ação. Educação e Pesquisa. 2005;31(3):483-502.

França SP, Pessoto UC, Gomes JO. Training in the family health program: different interpretations of home visits in the group of Presidente Prudente, in the state of São Paulo. Trabalho, Educação e Saúde. 2006; 4(1):93-108.

Freire MAM, Amorim WM. A enfermagem de saúde pública no Distrito Federal. Esc Anna Nery. 2008;12(1):115-24. 
Gaíva MAM, Siqueira VCA. A prática da visita domiciliária pelos profissionais da estratégia saúde da família. Cienc Cuid Saúde. 2011; 10(4):697-704.

Geovanini T, Moreira A, Dornelles S, Machado WCA. História da enfermagem: versões e interpretações. $3^{\mathrm{a}}$ ed. Rio de Janeiro: Revinter; 2010.

Gomes AMT, Oliveira DC de. A representação social da autonomia profissional do enfermeiro na Saúde Pública. Rev. Bras. Enferm.2005;58(4):393-398.

Gonçalves RBM. Práticas de saúde: processos de trabalho e necessidades. Centro de Formação dos Trabalhadores em Saúde da Secretaria Municipal da Saúde Cadernos CEFOR, 1 - Série textos /SP, 1992./mimeo/

Kawata LS, Mishima SM, Chirelli MQ, Pereira MJB, Matumoto S, Fortuna CM. Atributos mobilizados pela enfermeira na Saúde da Família: aproximação aos desempenhos na construção da competência gerencial. Rev. Esc. Enferm. USP [internet]. 2011 [citado 2014 jun 15];45(2):349-355. Disponível em: http://dx.doi.org/10.1590/S0080-62342011000200007.

Kawata LS et al. Os desempenhos da enfermeira na saúde da família: construindo competência para o cuidado. Texto contexto - enferm. 2013;22(4):961-970.

Laurell AC. A saúde-doença como processo social. In ED Nunes (org.). Medicina social: aspectos históricos e teóricos. São Paulo: Ed. Global;1983.

Lima ÍF dos $S$ et al. Integralidade na percepção dos trabalhadores de uma Unidade Básica de Saúde da Família. Rev. Esc. Enferm. USP. 2012;46(4):944-952.

Lopes WO, Saupe R, Massaroli A. Visita domiciliar: tecnologia para o cuidado, ensino e a pesquisa. Cienc Cuid Saude. 2008; 7(2):241-247.

Mandú ENT, Gaíva MAM, Silva MA, Silva ANM. Visita domiciliária sob o olhar de usuários do programa saúde da familia. Tex Contex Enferm. 2008;17(1):131-40.

Marx K. O Capital: crítica da economia política. 4ed. Rio de Janeiro: Civilização Brasileira; 1980.

Matumoto $\mathrm{S}$ et al. Discussão de famílias na estratégia saúde da família: processo de trabalho em construção. Rev. Esc. Enferm. USP. 2011;45(3):603-610. 
Matumoto S, Fortuna CM, Kawata LS, Mishima SM, P MJB. A prática clínica do enfermeiro na atenção básica: um processo em construção. Rev. Latino-Am. Enfermagem. 2011;19(1):123-130.

Mazza MMPR. A visita domiciliária como instrumento de assistência de saúde. Rev. bras. crescimento desenvolv. Hum. 1994;4(2):60-8.

Mendes EV. O cuidado das condições crônicas na atenção primária à saúde: o imperativo da consolidação da estratégia da saúde da família. Brasília: Organização Pan-Americana da Saúde; 2012. p.512.

Mendonça MK. Licença, posso entrar? As visitas domiciliares nos programas de Agentes Comunitários de Saúde e Saúde da Família e a integralidade [tese]. São Paulo: Faculdade de Medicina, Universidade de São Paulo; 2008.

Miranda MG, Resende ACA. Sobre a pesquisa-ação na educação e as armadilhas do praticismo. Rev bras educ. 2006;11(33):511-518.

Molina TM. Historia de la enfermería. $2^{\mathrm{a}}$ ed. Buenos Aires: Inter-Médica; 1973.

Moretti-Pires RO, Ferro SBG, Büchele F, Oliveira HM de, Gonçalves MJF. Enfermeiro de Saúde da Família na Amazônia: conceitos e manejo na temática do uso de álcool. Rev. Esc. Enferm. USP. 2011;45(4):926-932.

Morita MC, Codato LAB, Higasi MS, Kasai MLHI. Visita domiciliar: oportunidade de aprendizagem na graduação em Odontologia. Rev Odontol UNESP. 2010; 39(2): 75-79.

Morosini MVGC. Modelos de atenção e a saúde da família. Rio de Janeiro: EPSJV/Fiocruz; 2007.

Mumford D. Some aspects of health visiting. Int. J. Nurs. Stud. 1968; 5: 195-203.

Nakamura E, Gutierres KA, Cohn A. O traço normatizador das práticas das equipes do PSF. In: Cohn A. (org.). Saúde da família e SUS: convergências e dissonâncias. Rio de Janeiro: Beco do Azougue; São Paulo: CEDEC;2009.

Nascimento MS, Nascimento MAA. Prática da enfermeira no Programa de Saúde da Família: a interface da vigilância da saúde versus as ações programáticas em saúde. Ciênc. saúde coletiva. 2005;10(2):333-45. 
Nauderer TM, Lima MADS. Imagem da enfermeira: revisão da literatura. Rev bras enferm. 2005; 58(1):74-7.

Nunes ED. Juan César García: pensamento social em saúde na América Latina. São Paulo: Cortez Editora; 1989.

Paixão W. História da Enfermagem. $5^{\text {a }}$ ed. Rio de Janeiro: Júlio C. Reis, 1979.

Peduzzi M, Silva AM, Lima MADS. Enfermagem como prática social e trabalho em equipe. In: Soares CB, Campos CMS, organizadoras. Fundamentos de Saúde Coletiva e o Cuidado de Enfermagem. São Paulo: Manole; 2013. p.265-292.

Pereira MJB. O trabalho da enfermeira no Serviço de Assistência Domiciliar - potência para (re) construção da prática de saúde e de enfermagem [tese]. Ribeirão Preto: Escola de Enfermagem de Ribeirão Preto, Universidade de São Paulo; 2001.

Pessoa VM, Rigotto RM, Arruda CAM, Machado MFAS, Machado MMT, Bezerra MGV. Pesquisa-ação: proposição metodológica para o planejamento das ações nos serviços de atenção primária no contexto da saúde ambiental e da saúde do trabalhador. Interface (Botucatu). 2013;17(45):301-314.

Pinto ESG, Menezes RMP de, Villa TCS. Situação de trabalho dos profissionais da Estratégia Saúde da Família em Ceará-Mirim. Rev. Esc. Enferm. USP. 2010;44(3):657-664.

Porto F, Amorim WM. Escolas e cursos de enfermagem na história da profissão no Brasil (1890-1922). Cultura de los cuidados. Año XIV, 1. Sem. 2010; 27: 40-45.

Reis AM dos, Soares CB, Campos CMS. Processo saúde-doença: concepções do movimento estudantil da área da saúde. Saude soc. [internet]. 2010 [citado 2014 jun 13];19(2):347-357. Disponível em: http://dx.doi.org/10.1590/S0104-12902010000200011.

Ribeiro EM, Pires D, Blank VMG. A teorização sobre processo de trabalho em saúde como instrumental para análise do trabalho no Programa Saúde da Família. Cad Saúde Pública. 2004; 20(2):438-446.

Ribeiro CJ. Probematizando o instrumento visita domiciliar. Sociedade em Debate. 2010; 16(1):209-221. 
Rizzotto MLF. História da Enfermagem e sua relação com a Saúde Pública. Goiânia: AB; 1999.

Rodrigues VM, Fracolli LA, Oliveira MAC. Possibilidades e limites do trabalho de vigilância epidemiológica no nível local em direção à vigilância à saúde. Rev. Esc. Enferm. USP. 2001;35(4):313-319

Roecker S, Marcon SS. Educação em saúde na estratégia saúde da família: o significado e a práxis dos enfermeiros. Esc. Anna Nery. 2011;15(4):701709.

Roecker S, Budó MLD, Marcon SS. Trabalho educativo do enfermeiro na Estratégia Saúde da Família: dificuldades e perspectivas de mudanças. Rev. Esc. Enferm. USP. 2012;46(3):641-649.

Roecker S, Nunes EFP de A, Marcon SS. The educational work of nurses in the Family Health Strategy. Texto contexto - enferm. 2013;22(1):157-165.

Roese A, Lopes MJM. A visita domiciliar como instrumento de coleta de dados de pesquisa e vigilância em saúde: relato de experiência. Rev Gaúcha Enferm. 2004; 25(1):98-111.

Romanholi RMZ, Cyrino EG. A visita domiciliar na formação de médicos: da concepção ao desafio do fazer. Interface (Botucatu). 2012;16(42):693705 .

Sakata KN, Almeida MCP, Alvarenga AM, Craco AM, Pereira MJB. Concepções da equipe de saúde da família sobre as visitas domiciliares. Rev Bras Enferm. 2007; 60(6): 659-64.

Salum MJL, Queiroz VM. A determinação social do processo saúde-doença. Disciplina Enfermagem em Saúde Coletiva: fundamentação e prática de 21/10/09. In: Documento Pedagógico da Disciplina Enfermagem Preventiva e Comunitária de 02/04/1996.

Sant'Anna CF, Cezar-Vaz MR, Cardoso LS, Bonow CA, Silva MRS da. Comunidade: objeto coletivo do trabalho das enfermeiras da Estratégia Saúde da Família. Acta paul. enferm. 2011;24(3):341-340.

Santos LA de C, Faria L. Saúde \& História. São Paulo: Editora Hucitec; 2010 .

Santos EM, Kirschbaum DIR. A trajetória histórica da visita domiciliária no Brasil: uma revisão bibliográfica. Rev Eletrônica de Enfermagem [Internet]. 2008;10(1):220-227. [citado 2013 Abr 22]. Disponível em: http://www.fen.ufg.br/revista/v10/n1/v10n1a20.htm. 
Santos EM, Morais SHG. A visita domiciliar na estratégia saúde da família: percepção de enfermeiros. Cogitare Enfermagem. 2001; 16(3): 492-7.

Santos VC, Soares CB, Campos CMS. A relação trabalho-saúde de enfermeiros do PSF no município de São Paulo. Rev. Esc. Enferm. USP. 2007;41(spe):777-781.

São Paulo (cidade). Secretaria Municipal de Saúde. Núcleo de Divulgação de Informações. [internet]. [citado 2013 Jul 18]. Disponível em: http://intranet.saude.prefeitura.sp.gov.br/areas/ceinfo/divulgacao/Coord_Re g_Saude.pdf.

Severino AJ. The production of knowledge, teaching/learning and education. Interface (Botucatu). 1998;2(3).

Silva GB. Enfermagem profissional: análise crítica. $2^{\mathrm{a}}$ ed. São Paulo: Cortez; 1989.

Silva JC, Morais ER, Figueiredo MLF, Tyrrell MAR. Pesquisa-ação: concepções e aplicabilidade nos estudos em enfermagem. Rev. Bras. Enferm. 2011;64(3):592-595.

Silva, BRB. Práticas de enfermeiras da USF Jardim Boa Vista: em pauta a participação social [dissertação]. São Paulo: Escola de Enfermagem, Universidade de São Paulo; 2012.

Smith J. The archive os the Health Visitor's Association in the Contemporary Medical Archives Centre. Medical History. 1995;39:358367.

Sossai LCF, Pinto IC. A visita domiciliária do enfermeiro: fragilidades X potencialidades. Cienc Cuid Saúde. 2010; 9(3):569-576.

Soares CB, Campos CMS, Leite AS, Souza CLL. Juventude e consumo de drogas: oficinas de instrumentalização de trabalhadores de instituições sociais, na perspectiva da saúde coletiva. Interface (Botucatu). 2009;13(28):189-99.

Soares CB, Campos CMS, Yonekura T. Marxismo como referencial teoricometodologico em saude coletiva: implicacoes para a revisão sistemática e sintese de evidencias. Rev. Esc. Enferm. USP. 2013;47(6):1403-1409. 
Soares CB, Cordeiro L, Campos CMS. Pesquisa-ação emancipatória: uma proposta metodológica essencial para a enfermagem. In: Seminário Nacional de Pesquisa em Enfermagem; 2013 jun. 3-5; Natal: Associação Brasileira de Enfermagem - Seção Rio Grande do Norte; 2013. p. A171178.

Stotz EN. Os desafios para o SUS e a educação popular: uma análise baseada na dialética da satisfação das necessidades de saúde. In: Rocha CMF et al. (Orgs.) VER-SUS Brasil. 2004;1:284-299.

Takahashi RF, Oliveira MAC. A Visita Domiciliária no Contexto da Saúde da Família. In: Brasil. Instituto para o Desenvolvimento da Saúde. Universidade de São Paulo. Ministério da Saúde. Manual de Enfermagem. Brasília: Ministério da Saúde; 2001.

Tanaka OY, Escobar EMA, Gimenez ASM, Camargo KG, Lelli CLS, Yoshida TM. Gerenciamento do setor saúde na década de 80, no Estado de São Paulo, Brasil. Rev. Saúde Pública. 1992;26(3):185-194.

Teixeira CP. Visita Domiciliar: um instrumento de intervenção. Sociedade em Debate. 2009;15(1):165-178.

Torres HC, Roque C, Nunes C. Visita domiciliar: estratégia educativa para o autocuidado de clientes diabéticos na atenção básica. Rev. enferm. UERJ. 2011; 19(1):89-93.

Thiollent M. Metodologia da pesquisa-ação. $18^{\mathrm{a}}$ ed. São Paulo: Cortez;2011.

Toledo RF, Giatti LL, Pelicioni MCF. Mobilização Social em Saúde e Saneamento em Processo de Pesquisa-ação em uma Comunidade Indígena no Noroeste Amazônico. Saúde soc. 2012; 21(1):206-218.

Trapé CA. Operacionalização do conceito de classes sociais em epidemiologia crítica: uma proposta de aproximação a partir da categoria reprodução social [tese]. São Paulo: Escolas de Enfermagem de São Paulo; 2011.

Trezza MCAF, Santos RM dos, Leite, JL. Enfermagem como prática social: um exercício de reflexão. Rev. Bras. Enferm. 2008; 61(6):904-908.

Tripp D. Pesquisa-ação: uma introdução metodológica. Educação e Pesquisa. 2005;31(3):443-466.

Valla VV, Stotz EN, Algebaile EB. Para compreender a pobreza no Brasil. Rio de Janeiro: Contraponto/Escola Nacional de Saúde Pública; 2005. 
Valente GSC, Manso CR, Maia AFCB, Ornelas ABC, Sá SP, Lindolpho MC. A experiência do acadêmico de enfermagem na visita domiciliar ao idoso que vive com demência. Rev enferm UFPE on line. 2010;4(3):1410416.

Viana N. A Constituição das Políticas Públicas. Rev Plurais [Internet]. 2006 [citado 2014 jun 7];1:94-112. Disponível em: http://www.nee.ueg.br/seer/ index.php/revistaplurais/article/viewFile/69/96.

Viana N, Soares CB, Campos CMS. Reprodução social e processo saúdedoença: para compreender o objeto da saúde coletiva. In: Soares CB, Campos CMS, orgs.. Fundamentos de Saúde Coletiva e o Cuidado de Enfermagem. São Paulo: Manole; 2013. p.117-142. 
Apêndices 
APÊNDICE I - ROTEIRO PARA MATERIAL AUDIOVISUAL DE VISITA DOMICILIAR

"QUE ÓCULOS VOCÊ USA?"

ROTEIRO PARA MODELO DE VISITA DOMICILIAR AMPLIADA

São Paulo

2014 
"QUE ÓCULOS VOCÊ USA?"

ARGUMENTO

Ana é uma enfermeira da Atenção Básica, recém formada e que passou a integrar uma equipe de saúde da Família. Está animada para desenvolver as ações que aprendeu na graduação. Os problemas relacionados às formas de viver e trabalhar da população sempre a inquietaram.

A médica de equipe passa para Ana o prontuário de uma adolescente gestante que não tem comparecido às consultas de pré-natal, salientando a necessidade de uma Visita Domiciliar (VD) porque precisa fechar as metas do pré-natal.

Ana, com o prontuário em mãos, sai a procura do Agente Comunitário de saúde responsável pela área de abrangência em que reside a adolescente, porém, ao ser informada por outro profissional que - Agente Comunitário de Saúde (ACS) está em VD, decide ir para a visita sozinha para adiantar as atividades.

A enfermeira vai até a comunidade onde fica a casa da usuária, sem um prévio reconhecimento do território. Ao chegar na comunidade, é alertada por meninos que estavam correndo na rua, que não era um bom dia para estar ali, receosa e frustrada, ela retorna para a UBS.

De volta ao serviço, em reunião com a equipe, Ana relata seu insucesso ao tentar realizar sua primeira VD. A equipe discute o caso e destaca a importância de fazer o reconhecimento prévio das características do território, utilizando banco de dados, mapa da área, tabelas, etc.

Discutem em equipe a importância do planejamento e participação do ACS, e que, adentrar no espaço privado "não é chegar chegando", tem que pedir licença.

$\mathrm{Na}$ segunda tentativa de VD, a enfermeira vai até a casa da adolescente, juntamente com a ACS daquela área.

A partir do instrumental que dispõe no momento, realiza primorosamente os cuidados à puérpera e ao bebê, nesse caso, primordialmente o instrumental da clínica. 
Porém, ao deparar-se com os problemas sociais daquela familia, a enfermeira percebeu que havia mais coisas a se fazer naquela casa.

Ela se deu conta de que com o instrumental que a clínica dispõe não é possível responder as necessidades sociais de saúde em uma VD, e que esse instrumento do processo de trabalho é apenas o começo para desenvolver ações com distintos setores e com a mobilização da população, para atingir a base material de vida da totalidade. 
ATORES E FIGURINO

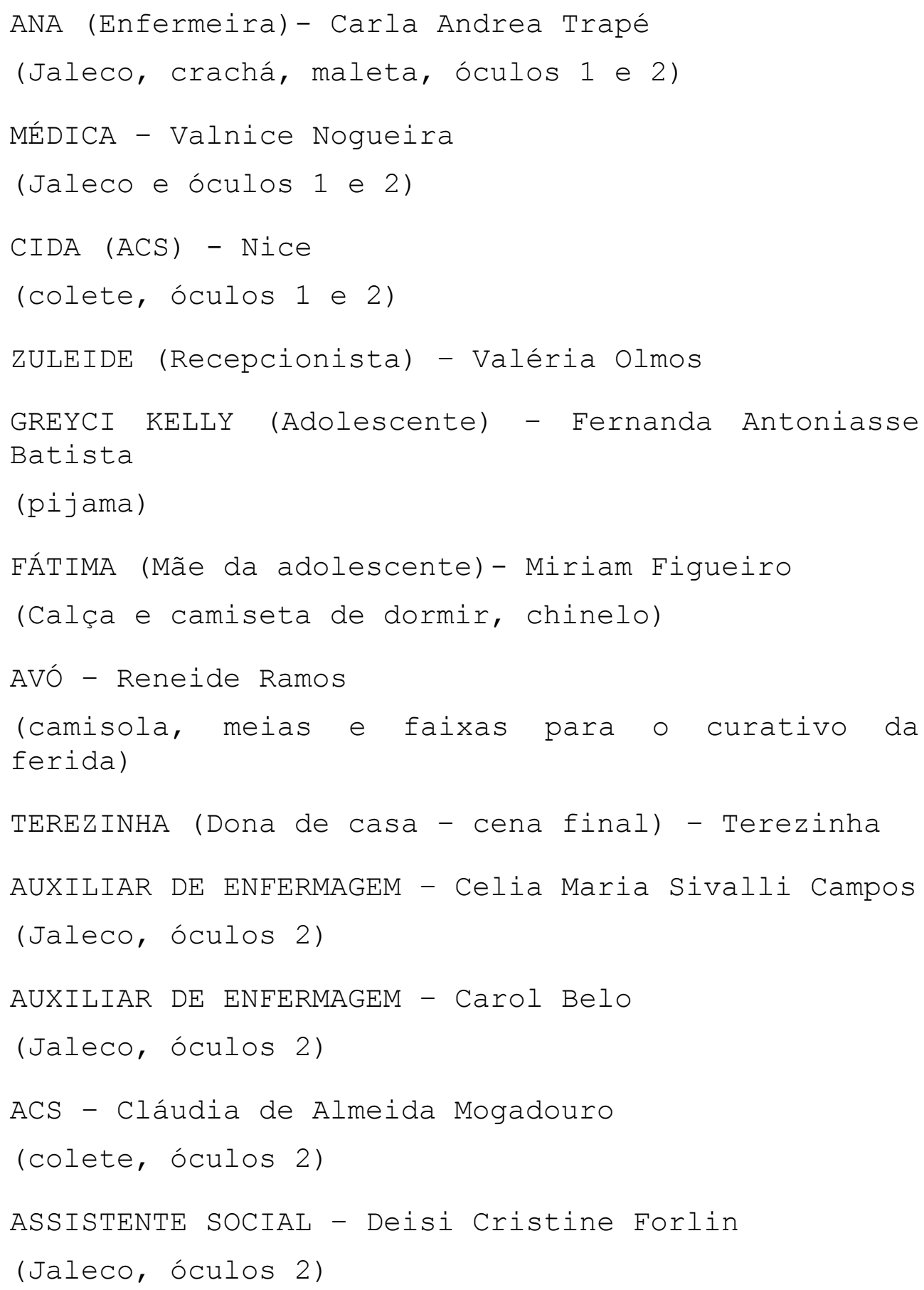


PASSOS RELEVANTES NA VD PARA RECORTAR NECESSIDADES DE SAÚDE COMO OBJETO DO PROCESSO DE TRABALHO

1) Planejamento da VD

Reconhecer a base material de vida daquelas pessoas - o território:

- Identificar a presença do Estado (instituições sociais: escolas, cursos preparatórios para o trabalho, creches, serviços de saúde, segurança pública; serviços de infra estrutura: coleta de lixo, distribuição de água tratada, luz, esgoto às residências, iluminação pública; transportes; pavimentação das ruas; monitoramento das condições de moradias e áreas de risco; presença de áreas verdes, parques, áreas de lazer)

- Conhecer outros equipamentos sociais e organizações, para sistematizar a rede de apoio, para ações intersetoriais.

2) Pedir licença

- Há distintas formas do profissional chegar até o domicílio, em áreas com maior poder aquisitivo, a licença é formal, enquanto que nas áreas mais empobrecidas, pode ocorrer o poder paralelo de ocupações ilegais;

- O saber "pedir licença" faz parte do planejamento, de conhecer o território.

3) Trocar a "lente"

- Ao adentrar no espaço privado, o profissional deve desenvolver o cuidado que motivou a VD. O cuidado operacionaliza-se por um conjunto de instrumentos, para responder à complexidade das necessidades de saúde. Um desses conjuntos fundamenta-se nos saberes da clínica, com ferramentas possíveis de serem manejadas pelo profissional individualmente e que incidem 
no corpo biopsíquico. Mas também, deve trocar as "lentes" do óculos, para compreender as raízes dos problemas manifestados no corpo biológico.

4) A VD não é a solução em si, mas o começo - para identificar o problema

- A VD tem duas possibilidades, 1) intervir num determinado problema, geralmente "disparado" por uma disfunção (no âmbito do corpo biopsíquico, ou no âmbito da dinâmica familiar). Esse, geralmente utiliza dos instrumentais da clínica, do tratamento individual, que tem fim em si mesma, ou no máximo, encaminha para outros atendimentos em serviços de saúde. Mas também tem essa potencia em atingir a raiz desses problemas refletidos no corpo biológico. O trabalhador tem que ter consciência e domínio disso, tanto para não ficar só na frustração, mas para acionar a rede interdisciplinar $e$ intersetorial, que é a única forma de atingir os determinantes sociais dos problemas que atingem os distintos grupos sociais;

- O setor saúde não tem ferramentas para dar conta das necessidades de reprodução social daquele indivíduo ou família, mas com a discussão e reflexão interdisciplinar, para mobilizar ações intersetoriais, que são as que tem potência para atingir os determinantes sociais dos problemas daquela população;

- o "start" do problema ocorre na visita, não é para levar respostas, mas para trazer questões para mobilizar o trabalho;

- É preciso espaços formais para discutir ações que ampliem, para dar conta dos problemas levantados na VD. 
5) Mobilizar a população

- Para chegar à raiz dos problemas que envolvem as condições de vida naquele bairro/população, deve ter o envolvimento das pessoas que vivem lá, pois o profissional não tem como saber e conhecer tudo sobre aquele território.

6) Desenvolver ações que instrumentalizem a população, com caráter emancipatório para atingir mudança em sua base material de vida. 
ROTEIRO

\section{CENA 01 - INTERIOR - CONSULTÓRIO DE ENFERMAGEM - UBS /DIA}

Enfermeira ANA, esta no consultório/ de enfermagem e chega a MÉDICA da equipe com um caso de gestante faltosa.

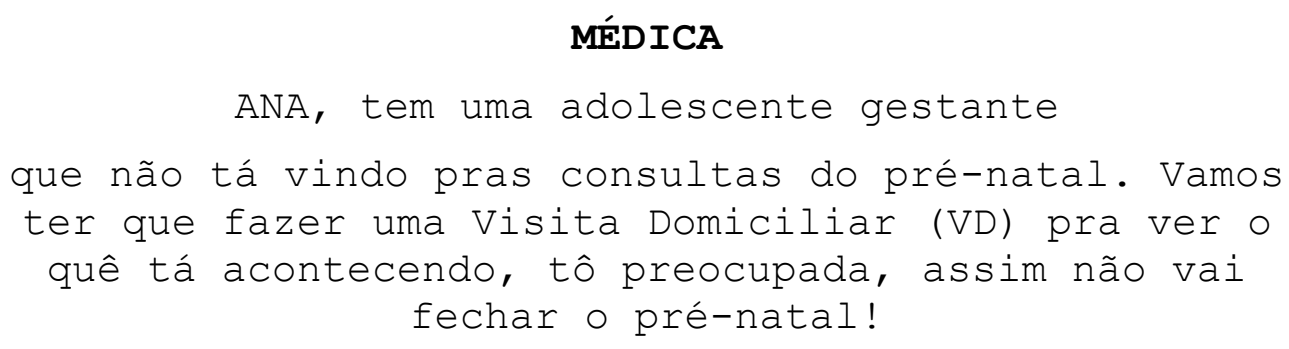

ANA

Tá bom... vou falar com a ACS pra gente ir fazer uma VD.

\section{CENA 02 - INTERIOR UBS/DIA}

ANA sai para procurar a ACS na unidade. Pergunta para a recepcionista se sabe onde a Cida está.

\section{ANA}

Zuleide, você sabe onde tá a Cida?

ZULEIDE - recepcionista

Acho que saiu pra fazer VD.

ANA - pensamento

Eu sei o caminho, vou adiantar o trabalho...

\section{CENA 03 - INTERIOR - PORTA DE SAÍDA - UBS/DIA}

ANA na porta da unidade, de costas para a câmera, tira da maleta que tem nas mãos os óculos (óculos 1- da clínica), os coloca e sai para fazer a VD. 


\title{
CENA 04 - EXTERIOR - TERRITÓRIO/DIA
}

Diversas TOMADAS para mostrar o entorno da Unidade Básica de Saúde, com destaque para a heterogeneidade das condições de vida características do bairro (trilha - Ivone Lara).

\section{CENA 05 - INTERIOR - CONSULTÓRIO REUNIÃO DA EQUIPE/DIA}

ANA na porta do consultório, de frente para a câmera, tira do rosto e recoloca os óculos 1 na maleta (óculos 1- da clínica).

Expressão de decepção/frustração.

\author{
ANA \\ Puts, a VD "miou". \\ MÉDICA \\ O que aconteceu ANA?
}

\begin{abstract}
ANA
Poxa, minha primeira visita, eu toda empolgada e acabei pagando o maior mico...

Tentei ir até a casa daquela adolescente gestante pra fazer a VD. Mas, na entrada da viela vieram uns meninos correndo, me avisaram que não era um bom dia pra entrar lá.

\section{MÉDICA}

Você foi sozinha? Por que?

\section{ANA}

A Cida tinha saído pra fazer VD e eu achei que tudo bem se eu fosse sozinha mesmo...

\section{MÉDICA}

Perai Ana, não funciona assim, precisa planejar a

VD. Primeiro a gente lê o prontuário, avalia as características da área, discute aqui com a equipe. Quer ver? Vamos pensar aqui junto com a equipe este caso.

Câmera faz close no prontuário, dados (planilhas, tabelas, mapas,...) 
Bom dia Fátima, como estão as coisas? não te vi mais lá no posto...

\section{FÁTIMA}

Pois é Cida, tudo indo, né? A gente vai levando...

\section{CIDA}

É né... olha, essa é a nova enfermeira da Unidade de Saúde, a Ana, a gente veio ver como que tá a Greyci Kelly e o bebê. É menino ou menina?!

\section{FÁTIMA}

É menino

\section{ANA}

Bom dia Fátima

\section{FÁTIMA}

Podem entrar, eles tão deitados com a vó.

Greyci!! Tem visita! As moça do postinho!!

(Gritando)

Gente, só não repara que a gente acabou de levanta.

\section{CENA 09 - INTERIOR - CASA DA ADOLESCENTE}

\section{GESTANTE/DIA}

ANA e CIDA entram e se deparam com a adolescente deitada em um colchão, ao lado do bebê e da avó.

A avó tem "panos" enrolados no tornozelo, não anda.

Todos dormem na mesma cama.

ANA - OLHAR de espanto ao chegar no cômodo

Bom dia Greyci Kelly, tudo bem com você? eu sou a Ana, a nova enfermeira do posto. A gente veio ver como você tá, quer dizer, agora vocês né... você não voltou pras consultas do pré-natal... o que aconteceu? Você sumiu...

\section{GREYCI KELLY}

$$
\text { Oi, a gente tá bem. }
$$$$
\text { Avó - falas em paralelo }
$$

Eu não levanto minha filha, minha perna dói...

\section{ANA}

E vocês todas dormem nesse colchão? 
Sim.

ANA

E O pai da criança?

AVó - riso irônico

Xii... melhor nem pergunta...

FÁTIMA - repreendendo

Mãe! !

AVó - mostrando onde tem as úlceras de pressão

Minha filha, olha minha situação, isso tudo é pano... ai... ai... ai...

CÂMERA EMBAÇA - simbolizando ANA meio zonza pela complexidade da situação enquanto GREYCY KELLY, FÁTIMA e a AVÓ discutem.

ANA - olhando para a MALETA, tira os óculo (óculos

1), olha para eles e para a CÂMERA com expressão entre desespero e desamparo

E agora, o que eu faço? - pensamento

(Respira fundo) Close na colocação dos óculos, tira um estetoscópio da maleta e inicia o protocolo (a clínica)

ANA

Me conte Greyci, como foi o teu parto? E o neném tá mamando direito?

Coloca ela deitado aqui pra eu examinar ele, se tá tudo bem...

\section{PROCEDIMENTOS CLÍNICOS}

\section{(Gravado todo o atendimento ao bebê a à gestante, como é realizado na VD, depois será editado)}

Câmera aproxima no procedimento e distancia para a cena. $\mathrm{Na}$ aproximação do procedimento a imagem coincide com áudio de orientações. No distanciamento para a cena, sem falas (som é de trilha música instrumental?)

Discorrem sobre como foi o parto. A enfermeira realiza os cuidados com instrumentais da clínica ao bebê e a gestante, foco da visita.

A enfermeira termina a VD à gestante e ao bebê e levanta algumas questões sobre o estado da idosa. 
Utiliza os conhecimentos que dispõe (a clínica), fazendo orientações: vocês sabem que essas feridas acontecem por ficar muito tempo em uma mesma posição? Hoje eu não tenho materiais pra fazer o curativo, mas essa idosa precisa ser avaliada. Vou marcar outra VD, com a médica, pra vir ver direito essas questões da idosa.

Ana termina os procedimentos, informa que vai marcar outra VD com a médica, para avaliar a idosa. Ana e Cida se despedem.

\section{CENA 10 - PORTA DA CASA DA ADOLESCENTE GESTANTE/DIA ANA}

(Olha para a câmera e para o óculos 1 na mão, que acabou de tirar) e pensa:

Mas será que é só isso? É só pra isso que a VD serve?

\section{CENA 11 - INTERIOR UBS EM REUNIÃO DE EQUIPE/DIA \\ ANA}

Nossa, que situação difícil, gente! Eu cheguei lá com um OLHAR, mas agora consigo

ENXERGAR que tem muito mais coisas que explicam aquela situação...

TODOS COLOCAM OS ÓCULOS 2

Elas dormem todas num mesmo colchão, e aquele bebê junto, a avó não deambula e precisa de fralda...

\section{ASSISTENTE SOCIAL}

\section{Como elas se sustentam?}

\section{MÉDICA}

Pelo que sei é a Fátima quem sustenta a casa.

\section{CIDA}

Só que ela está desempregada, e a Greyci parou de estudar desde que engravidou.

\section{ACS - Cláudia}

E agora mais um bebê... Será que o pai ajuda?

\section{CIDA}

... O pai sumiu, assim que ela engravidou... E tem ainda a avó que é dependente... 
ANA

Gente! Vocês já repararam que os adolescentes daqui não tem perspectiva de futuro?

\section{AUXILIAR DE ENFERMAGEM - Celia}

É mesmo... nem estudar tem garantido o futuro, que profissão vão ter? no que vão trabalhar? a maioria vira chefe de família cedo, tem que ajudar nas despesas da casa ... $E$ eu nem tinha reparado que também não tem nada pra eles na atenção básica... Pensava que tava bem bom, que o que eles precisavam era vacina e consulta

\section{CIDA}

$\mathrm{V}$ e r d a d e... Dá pra entender porque essas meninas tão tendo filho, é que a UBS só faz teste de gravidez e pré natal. A saúde está muito restrita, precisava que a gente pensasse em práticas que envolvessem os jovens e as famílias para entenderem o problema e buscassem soluções conjuntas, com outros moradores do bairro.

\section{MÉDICA}

Mas a gente faz tanta coisa, parece que tamo dando tiro pra tudo que é lado...

\section{ACS - Cláudia}

Mas atingindo o que?

\section{CAROL}

As metas de produção!!!!

Em tom de desabafo, de reclamação: Tudo gira em torno de metas numéricas: é de consulta, é de VD, é de pré-natal...

\section{ANA}

Pois é, quando uma adolescente me procura pra saber se está grávida eu ofereço o teste de gravidez e o pré-natal. Será que a gente não tem nada mais a oferecer? A gente deveria, muito além disso, discutir a vida, o bairro, o trabalho, a escola, os espaços de lazer... o futuro.

\section{ASSISTENTE SOCIAL}

E tem muitas pessoas que nem sabem sobre os direitos que tem, de fralda, do LOAS, das bolsas... 
CIDA

Mas, como é que dá pra fazer tudo isso?

\section{ASSISTENTE SOCIAL}

Cida, não dá pra fazer tudo isso na Unidade de Saúde, precisa ter ações com outras instituições sociais. Essa familia, por exemplo, sabe que existe o Conselho Gestor,

a Rede de Instituições do bairro, reunião de moradores? É fundamental construir grupos com os jovens.

\section{AUXILIAR DE ENFERMAGEM}

Cida, você pode avisar a FÁTIMA quando vai ter a próxima Reunião do Conselho Gestor?

\section{ACS}

Isso, tem também tem a reunião dos moradores na sexta à noite...

(Vozes da equipe vão diminuindo...)

\section{CENA 12 FINAL - PORTA DE OUTRA CASA/DIA}

TEREZINHA abrindo a porta de casa para recepcionar ANA $P$ CIDA.

TEREZINHA - (com cara de expectativa de ajuda) Nossa, que bom que vocês vieram!

Câmera foca em ANA e CIDA, que tiram os óculos 2 do bolso do jaleco, os colocam e olham para a câmera.

\section{ANA (olha para Cida e dirige-se à Terezinha)}

Podemos entrar?

\section{CRÉDITOS}

Fotos de reuniões do conselho Gestor, reuniões com a população, com os jovens. 


\section{ANEXO I - TERMO DE CONSCENTIMENTO LIVRE E} ESCLARECIDO

\section{TERMO DE CONSENTIMENTO LIVRE E ESCLARECIDO (TCLE)}

(oficinas)

\section{Nome da pesquisa: necessidades de saúde como objeto das políticas públicas: as práticas de enfermagem na Atenção Básica}

Convido você a participar de estudo sobre visita domiciliar (VD) operacionalizada ou supervisionada por enfermeiras na Atenção Básica (AB). O objetivo é compreender as características da VD, com a finalidade de propor um exemplar dessa atividade. O estudo está sob a responsabilidade da prof $^{a}$ Célia Maria Sivalli Campos, da Escola de Enfermagem da USP e será desenvolvido com enfermeiros.

Sua participação nos ajudará a compreender as características da VD na AB, com o intuito de, junto com vocês, aprimorarmos essa prática e, consequentemente, o cuidado à saúde da população sob a responsabilidade das UBS.

Ao final dessas oficinas será proposto um modelo de VD, que será gravado em áudio e vídeo, para ser utilizado como material pedagógico em cursos de formação de trabalhadores de saúde e em processos educativos nas UBS ou supervisões de saúde. Caso você opte por participar na etapa seguinte, para elaboração do vídeo, receberá um novo TCLE e seu nome constará na coautoria do modelo de VD.

Julga-se que não há riscos associados à sua participação nesta etapa da pesquisa, considerando-se que:

> Sua participação será em oficinas grupais, para discussão de temas associados ao trabalho em saúde na $\mathrm{AB}$, com duração aproximada de 3 horas. A atividade será gravada em áudio e você tem todo o direito de revisar a gravação e excluir parcial ou totalmente a gravação, se assim o desejar.

$>$ As informações que obtivermos serão sempre expressas como sendo as do grupo, nunca aparecerão como contribuições individuais; seu nome nesta etapa da pesquisa não será divulgado sob nenhuma hipótese, em qualquer apresentação ou publicação baseada em nosso estudo. 
Sua participação no estudo é totalmente voluntária e você pode se recusar a participar ou retirar suas informações a qualquer momento, mesmo após o término das oficinas, sem qualquer penalidade.

Se estiver esclarecida (o) e concordar em participar, por favor preencha e assine a seção que segue.

Se você tiver dúvidas ou perguntas, em qualquer momento da pesquisa, entre em contato comigo, Celia ((11) 3061-7652 ou celiasiv@usp.br) ou com o Comitê de Ética em Pesquisa da EEUSP ((11)3061-7548 ou edipesq@usp.br).

Você receberá uma cópia deste documento, que ficará em seu poder. Nós agradecemos a sua colaboração e o seu interesse em participar desta pesquisa.

Atenciosamente,

\section{Pesquisador Responsável}

$\mathrm{Eu}$, estou

esclarecida (o) e concordo em participar da pesquisa descrita.

Nome:

Assinatura:

Data: 


\title{
ANEXO II - APROVAÇÃO COMITÊ DE ÉTICA EM \\ PESQUISA DA ESCOLA DE ENFERMAGEM DA UNIVERSIDADE DE SÃO PAULO
}

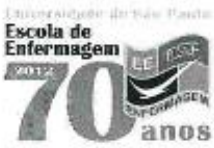

\author{
UNIVERSIDADE DE SÃO PAULO \\ ESCOLA DE ENFERMAGEM \\ Av. Dr. Enéas de Carvalho Aguiar, 419 - CEP 05403000 \\ Tel.: (11) 3061-7548/8858 - Fax: (11) 3061-7548 \\ São Paulo - SP - Brasil \\ E-mail: edipesqQusp.br
}

São Paulo, 16 de dezembro de 2011.

$\mathrm{Ilm}$. . Sr."

Prof." Dr." Célia Maria Sivalli Campos

Ref.: Processo n ${ }^{\circ}$ 1104/201 1/CEP-EEUSP - SISNEP CAAE: 0122.0.196.162-11

Prezada Senhora,

Em atenção à solicitação referente à análise do projeto "Necessidades de saúde como objeto das políticas públicas: as práticas de enfermagem na Atenção Básica", informamos que o mesmo foi considerado aprovado pelo Comitê de Ética cm Pesquisa da Escola de Enfermagem da Universidade de São Paulo (CEP/EEUSP).

Analisado sob o aspecto ético-legal, atende às exigências da Resolução n 196/96 do Conselho Nacional de Saúde.

Esclarecemos que após o término da pesquisa, os resultados obtidos deverão ser encaminhados ao CEP/EEUSP, para serem anexados ao processo.

Atenciosamente,

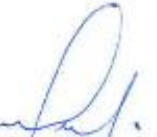

Prof Dr Prolo Maneghin

Vice-Coordenador do Comitê de Ética em Pesquisa da

Escola de Enfermagen da Uhiversidade de São Paulo 


\section{ANEXO III - APROVAÇÃO COMITÊ DE ÉTICA EM PESQUISA DA SECRETARIA MUNICIPAL DE SAÚDE DE SÃO PAULO}

\section{SÃOPAULO}

\section{SECRETARIA MUNICIPAL DA SAÚDE Comitê de Ética em Pesquisa/SMS}

CAAE: 0146.0.196.162-12

Săo Paulo, 24 de Fevereiro de 2012 PARECER NN 037/12-CEP/SMS

llma. Sra.

Célia Maria Sivalli Campos

Projeto de Pesquisa: Necessidades de saúde como objeto das politicas públicas: as práticas de enfermagem na Atençäo Básica

Pesquisador Responsável Célia Maria Sivalli Campos

Instituiçấ Proponente: Escola de Enfermagem da USP

Co-participante: SMS-SP. UBS- Id Boa Vista, V. Dalva, Săo Jorge, Id D'Abril, Paulo Vl, Real Parque,

Patrocinador: Apoio financeiro solicitado à FAPESP.

1. Sumário Geral do Protocolo

A ESF è apontada como a estratégia privilegiada pelo Ministério da Saùde (MS) brasleiro para a atençảo básica (AB) em saúde. O enfermeiro é parte integrante da equipe, que se encontra diante do desafio de desenvolver prabticas de cuidar do que respondam as necessidades de saúde dos diferentes grupos sociais que compōem a área de abrangelncla de uma UBS. Do ponto de vista teórico, necessidades de saùde são tomadas como necessidades de reproduçăo social, ou seja, necessidades ampliadas em relaçăo àquelas restritas a acesso a sevviços $e$ a problemas de saúde jâ instalados, que caracteri. zam as praticas tradicionais de $A B$.

Este estudo tem como objetivo geral compreender as caracteristicas das príticas operacionalizadas na AB pela ESF. com a particopaçio das enfermeiras, que apresentam potência para superar o modelo tradicional da atenç̧o à savide:

Participantes: Os sujeitos deste estudo serão 30 enfermeiros da ESF que trabalham em uma dada regiảo, com caracteristicas comuns de organizacāo do trabalho, respondendo a orientaçes de um mesmo gestor. Assim, o estudo será real. zado nas 6 UBS com ESF da Supervisão de Saùde do Butantă (UBS ja D'Abril - com 4 equipes, UBS Jd. Sà jorge - com 6 equipes, UBS Id. Paulo VI - com 6 equipes, UBS Vila Dalva - com S equipes, UBS xd. Boa Vista - com 6 equipes, UBS Real Parque - 2 equipes) e o Centro de Saúde Escola Samuel Barnsley Pessoa (1 equipe), integrante do projeto ana Deste. Essa superviș̃o de saùde foi a escolhida porque nela há uma articulaçăo entre a Secretaria Municipal da Saúde de Sảo Paulo por meio dessas UBS - e a Universidade de São Paulo (USP) - por meio das seguintes unidades de ensino: Escola de Enfermagem, Faculdade de Medicina, dos cursos de Fonoaudiologia, Fisioterapia, Terapia Ocupacional e da Faculdade de Odontologia.

Os sujeitos da pesquisa slo os enfermeiros integrantes das ESF que atuam no local de estudo eque re prontificarem a participar do estudo.

Procedimentos metodológicos: estudo de campo que mapeará as práticas desenvolvidas com a participaç̄o de enTermeiras nas 6 USF da Supervisăo de Saúde do Butantă, através de entrevistas; e procederá a observaclo particlpante de uma amotra composta por praticas consideradas exemplares, utilizando-se um roteiro de observaclio. O material da observacio serd analisado pepundo a catecoria de anslise necessidades de saude. Na terceira etapa pretende-se a producalo de material educativo, com vistas a apolar o desenvolvimento de priticas, em que os enfermeiros participam, que respondam a necessidades ampliadas de saúde na AB. OS sujeitos da pesquika serbào as enfermeiras das ES. Este projicto será submetido aos Comités de Etica em Pesquisa da EEUSP e da Secretaria Municipal da Saude de SP, respeitando-se os precertos ético-legais de investigaçlo vigentes no pais.

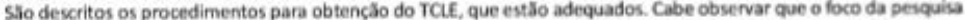
é a própria prática dos enfermeiros, que poderăo discutir e alterar o projeto. $O$ critério de incluašo ê o enfermeiro acritar participar do estudo.

- Nâo descrita a forma de recrutamento e a abordagem dos sujeitos de pesquisa; como o foco esta nas praticas

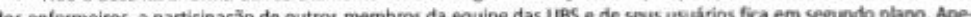
icher sar de estar prevista a assinatura do TCLI, pelos usaários, sujentos das praticas, e outros membros da equipe, os mes nos năo sẫo citados como participantes.

- O pesquisador năo faz referência à guarda segura do material nem informa como pretende manter o anonimato dos participantes na divulgaçăo dos resultados. (Resoluç̧̄o 196/96, IX. 2. E)

Rua General Jardim, 36 - $1^{\circ}$ andar - V. Buarque - fone: 3397.2464 - email: smscep@gmallicom

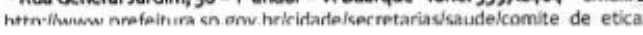




\section{SECRETARIA MUNICIPAL DA SAÚdE
Comitê de Ética em Pesquisa/SMS}

SÁO PAULO

2 - Considerações.

CAAE: 0146.0.196.162-12

A folha de Rosto está corretamente preenchida e o curriculo do pesquisador responsável está de acordo com a pro posta da pesquisa. Solicita-se a pesquisadora que apresente o link do curricu bo Lattes

Oorçamento detahado está adequado

O cronograma da pesquisa não está claro no que se refere ao inicio da coleta de dados condicionada à aprovaç̧ăo do CEP da SMS SP.

Há tratamento adequado dos dados, consonáncia entre objetivos e método, assim como relevància do tema, qué aborda a relaçâo saúde doenç nắa sxmente da perspectiva teórica, mas também a partir da analise das práticas dos enfermeiros, o que permitirá compreender se as ações dos agentes de saúde na AB correspondem ao seu discurso e ao dis. Avalla e mais que isso, se as práticas permitem nowos horizontes aos discursos. Avallią̧ăo dos riscos e beneficios

A metodoiogja é adequada aos objetivos e impöe baixa condiçăo de desconforto aos enfermeiros, participantes at: vos no desenho da pesquisa. O mesmo ocorre com os sujeitos das práticas. Tal condiçăo encontra-se devidamente justificada no TCLE, sendo que a possibilidade de beneficios pode compensar o desconforto. Sio previstos meios/pronte justica para atenuar/contornar eventuais desconfortos, no sentido de salvaguarda do sujeito de pesquisa.

Termo de Consentimento Livre e Esclarecido (TCLE)

$€$ conciso e objetivo e estab redigido na forma de convite à participação no estudo, sendo a linguagem adequada ao nivel sociocultural dos sujeitos de pesquisa; permite, portanto uma decisa̧o consciente do sujeito da pesquisa.

Há descriçăo suficiente dos procedimentos,

Há identificaç̧o de eventuais desconfortos, mas trata-se de procedimento de baixo risco

Os direitos fundamentais do sujeito de pesquisa estão garantidos sendo permitido ao voluntário sair da pesquisa, sem qualquer prejuizo.

Nao constam do TCLF as formas de contato com os CEPS da USP E DA SMS-SP, conforme texto abaixo

No caso de dúvidas ou denùncias sobre irregularidades éticas, entrar em contato corn o Comitê de ftica em pesquista da Secretaria Municipal de Saúde de Sảo Paulo, através do telefone 3397-2464 ou do email smscep@ grail. com, endereş Rua General Jardim 36,1 and

OBS.: Tadas as pendéncias apontadas nas Cansideraçbes acima, foram comigidas pelo pesquisador responsavel e aprovoda peios pareceristas.

\section{IIII - Situaçio do Protocolo - APROVADO}

Antes do inicio da coleta de dados, alertamos para a necessidade de contato $\infty \mathrm{m}$ o gerente da unidade quando nso foi eie quem autorizou a realizaçŏo da pesqui:e.

sujeito de pesquisa (ou seu representante) e o pesquisador responsibvel deverâo rubricar todas as fothas do Termo de Consentimento Lure e Esclarecido - TCEE apondo sua assinatura na ülima página do referido Termo, conforme Cart Circular no 003/2011 da CONEP/CNS.

Salientamos que o pesquisador deve desenvolver a pesquisa conforme delineada no protocolo aprovado. Eventuais

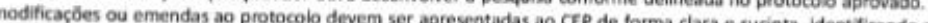
protocolo a ser modificado e suas justificativas.

Ao pesquisador cabe manter em arquivo, sob sua guarda, por 5 anos, os dados da pesquisa, contendo fichas indivi. duais e todos os demais documentos recomendados pelo CEP (Res. CNS 196/96 item D.2.

O relatório final deve ser apresentado ao CEP, logo que o estudo estiver concluido.

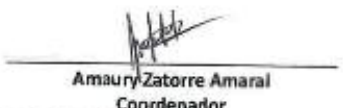

Coordenador

Comitê de f́tica em Pesquisa - CEP/SMS

- Rua General Jardim, 36 - $r^{*}$ andar - V. Buarque - fone: 3397.2464 - emalk smscep Pennellcom

http://www.prefeitura.sp.gov.br/cidade/secretarias/saudelcomite de etical 